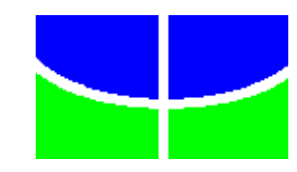

UNIVERSIDADE DE BRASÍLIA - UnB INSTITUTO DE LETRAS - IL

DEPARTAMENTO DE LÍNGUAS ESTRANGEIRAS E TRADUÇÃO - LET PROGRAMA DE PÓS-GRADUAÇÃO EM ESTUDOS DA TRADUÇÃO POSTRAD

\title{
A TRADUÇÃO DE RÓTULOS VIRTUAIS NO E- COMMERCE: UM OLHAR SOBRE COSMÉTICOS INFANTIS
}

RAQUEL BARROSO DE OLIVEIRA BORGES

\author{
DISSERTAÇÃO DE MESTRADO EM ESTUDOS \\ DA TRADUÇÃO
}

\author{
BRASÍLIA/DF \\ MARÇO/2016
}


UNIVERSIDADE DE BRASÍLIA - UnB

INSTITUTO DE LETRAS - IL

DEPARTAMENTO DE LÍNGUAS ESTRANGEIRAS E TRADUÇÃO - LET PROGRAMA DE PÓS-GRADUAÇÃO EM ESTUDOS DA TRADUUÇÃO POSTRAD

A TRADUÇÃO DE RÓTULOS VIRTUAIS NO E-COMMERCE: UM OLHAR SOBRE COSMÉTICOS INFANTIS

RAQUEL BARROSO DE OLIVEIRA BORGES

ORIENTADORA: CRISTIANE ROSCOE-BESSA

DISSERTAÇÃO DE MESTRADO EM ESTUDOS DA TRADUÇÃO

BRASÍLIA/DF

MARÇO/2016 
BORGES, Raquel Barroso de Oliveira. A tradução de rótulos virtuais no ecommerce: um olhar sobre cosméticos infantis. Brasília: Departamento de Línguas Estrangeiras e Tradução, Universidade de Brasília, 2016, 147 p.

Documento formal, autorizando reprodução desta dissertação de mestrado para empréstimo ou comercialização, exclusivamente para fins acadêmicos, foi passado pelo autor à Universidade de Brasília e acha-se arquivado na Secretaria do Programa. O autor reserva para si os outros direitos autorais, de publicação. Nenhuma parte desta dissertação de mestrado pode ser reproduzida sem a autorização por escrito do autor. Citações são estimuladas, desde que citada a fonte.

Barroso de Oliveira Borges, Raquel

BB732t A tradução de rótulos virtuais no e-commerce: um olhar sobre cosméticos infantis / Raquel Barroso de Oliveira Borges; orientadora Cristiane Roscoe-Bessa.

- - Brasília, 2016.

$147 \mathrm{p}$.

Dissertação (Mestrado - em Estudos da Tradução) - - Universidade de Brasília, 2016.

1. Tradução de rótulos. 2. Rótulos virtuais. 3. Tradução. 4. Traduçãosubstituição. 5. Comércio eletrônico. I. Roscoe-Bessa, Cristiane, orient. II. Título. 
UNIVERSIDADE DE BRASÍLIA - UnB

INSTITUTO DE LETRAS - IL

DEPARTAMENTO DE LÍNGUAS ESTRANGEIRAS E TRADUÇÃO - LET PROGRAMA DE PÓS-GRADUAÇÃO EM ESTUDOS DA TRADUÇÃO POSTRAD

A TRADUÇÃO DE RÓTULOS VIRTUAIS NO E-COMMERCE: UM OLHAR SOBRE COSMÉTICOS INFANTIS

RAQUEL BARROSO DE OLIVEIRA BORGES

DISSERTAÇÃO DE MESTRADO SUBMETIDA AO PROGRAMA DE PÓS-GRADUAÇÃO EM ESTUDOS DA TRADUÇÃO, COMO PARTE DOS REQUISITOS NECESSÁRIOS À OBTENÇÃO DO GRAU DE MESTRE EM ESTUDỎS DA TRADUÇÃO.

APROVADA POR:

CRISTIANE ROSCOE-BESSA (Universidade de Brasília) (ORIENTADORA)

JÚLIO CÉSAR NEVES MONTEIRO (Universidade de Brasília) (EXAMINADOR INTERNO)

ORLENE LÚCIA DE SABÓIA CARVALHO (Universidade de Brasília) (EXAMINADOR EXTERNO)

ALESSANDRA RAMOS DE OLIVEIRA HARDEN (Universidade de Brasília) (SUPLENTE)

BRASÍLIA/DF, 1ำ de ABRIL de 2016. 
Aos usuários de cosméticos infantis - sejam crianças, sejam adultos, sejam mães, sejam pais. Aos consumidores - sejam leitores ou não de rótulos; sejam fluentes ou não em línguas estrangeiras; sejam "e-consumidores" ou não. Por terem direito à tradução, o elo, a menor distância entre 0 que são e 0 que desejam consumir. 


\section{AGRADECIMENTOS}

A Deus, pelo dom da vida, por tudo que recebi até aqui, por ter me dado coragem para questionar realidades e, como consequência, ser a autora de uma nova forma de enxergar um fenômeno da atualidade, sem, contudo, deixar de reconhecer que ainda há tantas outras maneiras possíveis de fazê-lo.

Aos meus pais, Francisco e Rebeca, por dedicarem suas vidas para me conduzirem até aqui; por me mostrarem a todo momento, com doçura, que a educação é o maior legado que podem me deixar.

Ao meu irmão, Leonardo, que me motiva diariamente sem nem desconfiar, por ser meu anjo da guarda, e por se dispor a ir comigo aos supermercados e às farmácias fotografar rótulos de cosméticos infantis.

À minha avó, Sárvia, minha experiência de convivência mais longa com o amor mais carinhoso do mundo, por me ensinar a adorar os livros.

Ao Jader, pessoa com quem amo partilhar a minha vida, os meus sonhos, os meus medos, os meus estudos, as minhas descobertas e o meu conhecimento. Agradeço o carinho dispendido a este projeto, as críticas a ele delicadamente elaboradas, as sugestões e soluções mágicas e a inspiração para eu querer que ele fosse o melhor que já fiz, um orgulho nosso. Agradeço por sua capacidade de me trazer paz e resiliência na correria de cada semestre ao longo desses dois anos e, especialmente, da reta final. Não poderia me esquecer de agradecer, ainda, por compartilhar, comigo, os cosméticos infantis em nossa casa.

À Universidade de Brasília, por ter me recebido desde 2006, por me permitir realizar tantos sonhos, conhecer tantas pessoas que me inspiram, e por - ao longo da minha breve trajetória - me dar uma única certeza sobre as ciências: elas não nos apresentam respostas, mas infinitas perguntas.

À Cristiane Roscoe-Bessa, minha orientadora - coautora - amiga, por ter me apresentado um objeto de pesquisa tão intrigante, por ter optado por vivenciar 
de perto este projeto e por ter compreendido todas as fases pelas quais passei para chegar até aqui sem deixar de acreditar no meu, no nosso trabalho.

À Stella Tagnin, à Katarinna Pessoa e a toda a equipe do Projeto Corpus Multilíngue para Ensino e Tradução - CoMET, da Universidade de São Paulo (FFLCH/USP), que tive a oportunidade de visitar na fase inicial desta pesquisa, quando seus ventos ainda sopravam em outra direção.

Aos membros da Banca Examinadora, por aceitarem - de pronto - o convite para participarem deste momento único de minha trajetória.

Aos usuários de cosméticos infantis, por motivarem este estudo.

A todos que contribuíram, mesmo sem perceber, para que eu concluísse mais uma das etapas, de certo não a última, dos meus estudos. 
"Ainda há muito a ser inventado.

Muita coisa nova ainda vai acontecer.

Ninguém ainda faz ideia do impacto que a internet produzirá e de que em muitos aspectos estamos apenas no primeiro dia."

Jeff Bezos 
Nos últimos anos, percebeu-se um aumento exponencial de compras pela internet. Esse incremento provocou mudanças não apenas na maneira como os consumidores adquirem produtos, mas também no modo como eles se informam sobre o que adquirem. Esta pesquisa explorou as características de um gênero textual que emerge no contexto da tecnologia digital, mais especificamente do comércio eletrônico, diante da consolidação da oferta e da compra de produtos em lojas virtuais. Embora os rótulos virtuais cumpram papel similar ao dos rótulos físicos, observou-se que a oferta de produtos no $e$ commerce ainda carece de mecanismos de regulação e de fiscalização que subsidiem a sua tradução, o que tornou este estudo premente. A partir da observação de rótulos virtuais de cosméticos infantis fabricados e comercializados no Brasil, foram descritos os principais elementos físicos e linguísticos dos rótulos virtuais desses produtos a partir de textos autênticos da comunidade meta. Por conseguinte, foram fornecidos subsídios à tradução de rótulos virtuais de cosméticos infantis fabricados no exterior e comercializados no Brasil pela internet, de modo a auxiliar tradutores e outros profissionais envolvidos na importação, na rotulagem e na distribuição de produtos industrializados no comércio eletrônico.

Palavras-chave: rótulos virtuais; rótulos de cosméticos infantis; tradução; tradução-substituição; comércio eletrônico. 


\section{ABSTRACT}

In recent years, it is possible to see an exponential increase in internet shopping. This increase brought about changes not only in the way consumers purchase products, but also in the way they get information about what to buy. This research has explored the characteristics of a textual genre that emerges in the context of digital technology, specifically e-commerce, due to the consolidation of supply and purchase of products in virtual stores. Although virtual labels play a similar role to the physical labels, it was observed that the supply of products in the e-commerce still needs regulatory and supervisory mechanisms that support translation, which made this a very important study. Through the observation of virtual labels of products manufactured and sold in Brazil, the main physical and linguistic elements of virtual labels from authentic texts of the target community were described. As a consequence, subsidies were provided to the translation of virtual labels of children's care products manufactured overseas and sold in Brazil on the Internet, in order to help translators and other professionals involved in import, labeling and distribution of industrial products in e-commerce.

Keywords: virtual labelling; childcare products labelling; translation; translationsubstitution; e-commerce 
LISTA DE ILUSTRAÇÕES

\begin{tabular}{|c|l|c|}
\hline n.o & \multicolumn{1}{|c|}{ Título } & Pág. \\
\hline 1 & Exemplo de rótulo virtual de cosmético infantil & 60 \\
\hline 2 & $\begin{array}{l}\text { Exemplo de rótulo virtual de cosmético infantil em rede social } \\
\text { (Instagram) }\end{array}$ & 67 \\
\hline 3 & Símbolo representativo da vida útil dos produtos cosméticos & 77 \\
\hline 4 & Exemplo de imagem do Sabonete Líquido Angry Birds Pig 250ml & 84 \\
\hline
\end{tabular}




\begin{tabular}{|l|l|}
\hline ABIHPEC & $\begin{array}{l}\text { Associação Brasileira da Indústria de Higiene Pessoal, Perfumaria } \\
\text { e Cosméticos }\end{array}$ \\
\hline ABRE & Associação Brasileira de Embalagem \\
\hline ANVISA & Agência Nacional de Vigilância Sanitária \\
\hline CDC & Código de Defesa do Consumidor \\
\hline ECA & Estatuto da Criança e do Adolescente \\
\hline FDA & Food and Drug Administration \\
\hline PLS & Projeto de Lei do Senado \\
\hline Procon/SP & Fundação de Proteção e Defesa do Consumidor de São Paulo \\
\hline RDC & Resolução da Diretoria Colegiada \\
\hline SEBRAE & Serviço Brasileiro de Apoio às Micro e Pequenas Empresas \\
\hline
\end{tabular}




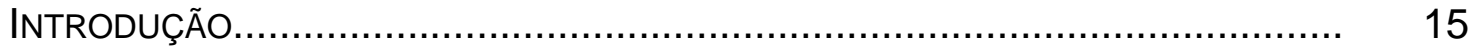

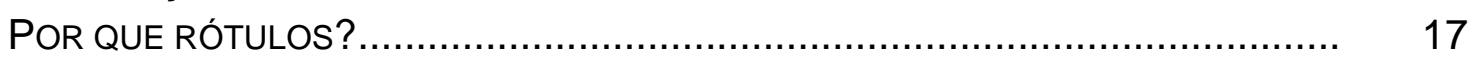

ORGANIZAÇÃO DOS CAPÍTULOS...................................................... 18

1. REFERENCIAL TEÓRICO................................................................. 20

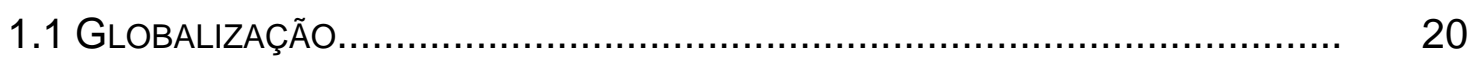

1.2 LOCALIZAÇÃO.......................................................................... 22

1.2.1 Paixão nacional: expresso ou coado?.................................. 23

1.2.2 A indústria da localização.................................................... 25

1.2.2.1 A localização de apps.............................................. 27

1.3 TRADUÇÃO-SUBSTITUIÇÃO.......................................................... 29

1.4 LEGISLAÇÃO REVISITADA...................................................... 31

1.4.1 Sabonetes são cosméticos? .............................................. 32

1.4.2 Quem é criança?........................................................... 34

$1.4 .3 \mathrm{O}$ que são rótulos, afinal? .................................................. 35

1.4.4 O Código de Defesa do Consumidor..................................... 35

1.4 .5 A legislação sanitária....................................................... 39

1.4.5.1 O click saudável........................................................ 40

2. METOdOLOGIA....................................................................... 43

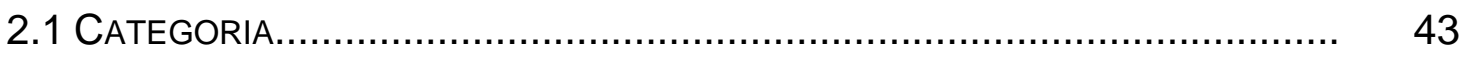

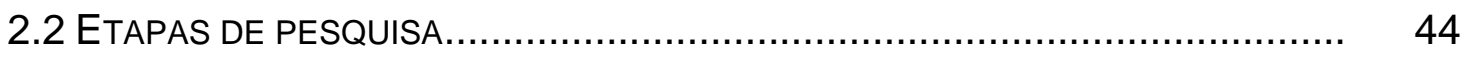

3. O MERCADO DE COSMÉTICOS INFANTIS: A INTERNET INAUGURA UMA NOVA MANEIRA DE COMÉRCIO............................................................. 46

3.1 O MERCADO DE COSMÉTICOS INFANTIS........................................ 46

3.2 DA MERCEARIA À INTERNET: O BOOM DO E-COMMERCE....................... 49

4. POR UMA NOVA DEFINIÇÃO DE RÓTULOS......................................... 55

4.1 BREVE INTRODUÇÃO............................................................... 56

4.2 DEFINIÇÃO DE RÓTULOS............................................................... 56

4.3 ROTULAGEM NA ERA DIGITAL: OS RÓTULOS VIRTUAIS.............................. 60

4.4 RÓTULOS VIRTUAIS: A INOVAÇÃO TECNOLÓGICA E O SURGIMENTO DE UM NOVO GÊNERO TEXTUAL

5. RÓTULO: FONTE DE INFORMAÇÃO, IDENTIDADE DO PRODUTO E DIFUSÃO DE VALORES CULTURAIS.

5.1 RÓTULO COMO FONTE DE INFORMAÇÃO............................................ 67

5.2 RÓTULO COMO IDENTIDADE DO PRODUTO........................................... 71

5.3 RÓTULO COMO DIFUSOR DE VALORES CULTURAIS............................... 73

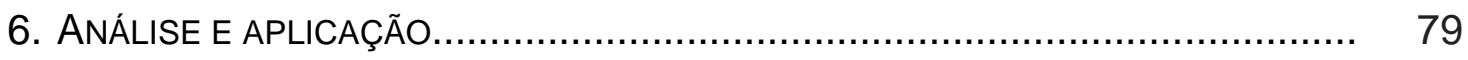

6.1 INDÚSTRIA E E-COMMERCE BRASILEIROS....................................... 79

6.1.1 Sites........................................................................... 79

6.1.2 Marcas........................................................................... 80

6.1.3 Produtos.................................................................. 81 


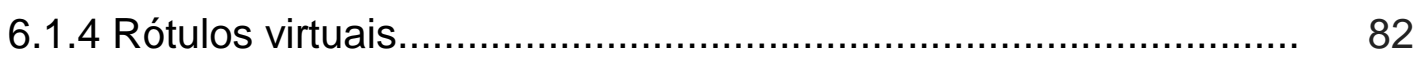

6.1.4.1 Elementos constituintes................................................... 82

6.1.4.1.1 Nome do produto e grupo/tipo a que pertence............. 83

6.1.4.1.2 Imagem do produto.................................................. 83

6.1.4.1.3 Descrição do produto............................................... 84

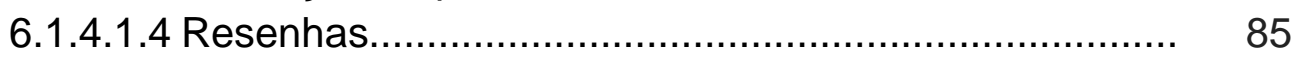

6.1.4.1.5 Outros elementos................................................ 86

6.1.4.1.6 Considerações finais sobre os elementos físicos dos rótulos virtuais.......................................................... 86

6.1.4.2 Elementos linguísticos.................................................. 88

6.1.4.2.1 Imperativo................................................................ 88

6.1.4.2.2 Pronomes pessoais e possessivos de segunda pessoa 89

6.1.4.2.3 Orações reduzidas de gerúndio................................... 91

6.1.4.2.4 Diminutivo............................................................ 91

6.1.4.2.5 Vocabulário............................................................ 92

6.1.4.2.6 Claims.................................................................... 96

6.1.4.2.7Considerações finais sobre os elementos linguísticos dos rótulos virtuais....................................................... 101

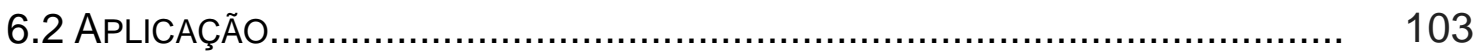

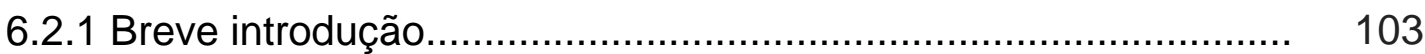

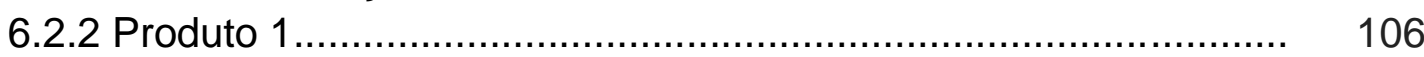

6.2.2.1 Tradução.............................................................. 107

6.2.2.2 Observações sobre a tradução.......................................... 108

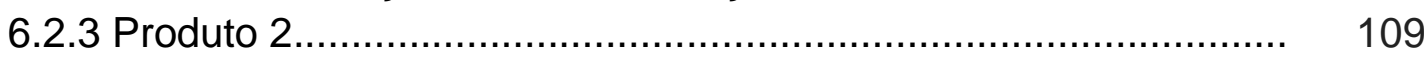

6.2.3.1 Tradução..................................................................... 110

6.2.3.2 Observações sobre a tradução.......................................... 111

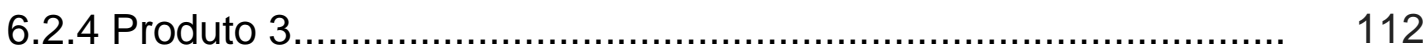

6.2.4.1 Tradução..................................................................... 113

6.2.4.2 Observações sobre a tradução.......................................... 115

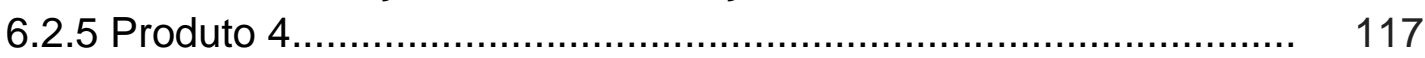

6.2.5.1 Tradução.................................................................... 119

6.2.5.2 Observações sobre a tradução......................................... 121

CONSIDERAÇÕES FINAIS..................................................................... 123

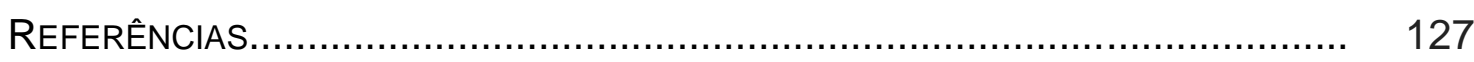

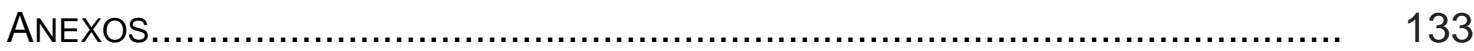

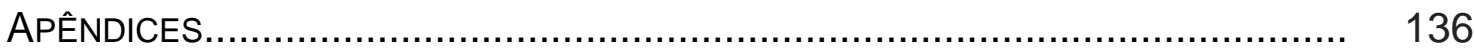




\title{
INTRODUÇÃO
}

\begin{abstract}
Existe na Internet uma livraria virtual chamada amazon.com, que tem mais de um milhão de títulos de livros, que você pode pesquisar usando palavras-chave, e comprar com um simples clique do mouse. Onde está essa livraria? Não interessa, pode estar em qualquer lugar, inclusive num fundo de garagem numa cidadezinha do interior de um país qualquer [...]. É a economia global, plugada na cultura global, e vice-versa.
\end{abstract}

SABBATINI, 1996

A livraria - se assim ainda for possível chamá-la - a que se refere o trecho epigrafado representa o maior ícone desta pesquisa: o comércio eletrônico. Se o paraíso, para Jorge Luiz Borges, era uma espécie de livraria (ou de biblioteca, ambas as traduções são encontradas), para Jeff Bezos ${ }^{1}$ também: uma livraria virtual, porém, que, quando pudesse ser acessada por qualquer usuário da internet, abriria uma "estranha janela para o comportamento humano" (STONE, 2014, p. 17).

Esta pesquisa se propõe a explorar as características de um gênero textual que emerge no contexto da tecnologia digital, mais especificamente do comércio eletrônico, tendo em vista a consolidação da oferta e da compra de produtos em lojas virtuais. Esse gênero não é totalmente inédito, tendo em vista que, assim como os rótulos afixados em recipientes físicos, ele se ocupa da divulgação de informações e da comercialização de produtos, porém, em um ambiente virtual de consumo. Esses rótulos, denominados nesta pesquisa de "virtuais", não passam de adaptações daqueles já existentes, que foram incorporados às tecnologias encontradas atualmente pela sociedade.

Embora cumpram papel similar ao dos rótulos físicos, os rótulos virtuais que estampam a oferta de produtos importados nas lojas virtuais brasileiras ainda carecem de mecanismos de regulação e de fiscalização do ponto de vista da tradução, área em que esta pesquisa se concentra, o que justifica a premência deste estudo. $O$ fato é que os rótulos dos produtos importados e comercializados em lojas físicas no Brasil, embora ainda estejam longe do

\footnotetext{
${ }^{1}$ Jeff Bezos é o Chief Executive Officer (CEO) da Amazon.com, a maior loja virtual do mundo.
} 
ideal, são superiores aos rótulos virtuais quando se trata de acesso às informações prestadas.

Esse avanço, do ponto de vista da rotulagem física, pode ser atribuído, em parte, ao advento do Código de Defesa do Consumidor (CDC), que determina que a língua portuguesa - empregada com clareza, precisão e objetividade - seja 0 instrumento de comunicação entre o produto e 0 seu potencial comprador, e à Agência Nacional de Vigilância Sanitária (ANVISA), que regulamenta a rotulagem de produtos cosméticos, além de fiscalizá-los e de registrá-los antes de disponibilizá-los no mercado. Entretanto, até o momento, as normas e as orientações oriundas tanto do CDC quanto da ANVISA não se aplicam ao comércio eletrônico, embora já haja iniciativas nesse sentido, como será apresentado na revisão da legislação atinente à área, o que desperta o interesse desta pesquisadora em buscar mecanismos que possam contribuir para o trabalho de tradutores no ambiente virtual de consumo.

Esta pesquisa pretende, a partir da observação de rótulos virtuais de cosméticos infantis fabricados e comercializados no Brasil, descrever os principais elementos físicos e linguísticos desse novo gênero textual a partir de textos autênticos desta comunidade meta e, por conseguinte, subsidiar a tradução de rótulos virtuais de cosméticos infantis fabricados no exterior e comercializados no Brasil via web. Pretende-se desenvolver um exame descritivo dos diversos elementos que envolvem este tipo de tradução a fim de sistematizar procedimentos que sirvam de auxílio a tradutores e a outros profissionais envolvidos na importação, na rotulagem e na distribuição desses produtos industrializados.

A necessidade de dar continuidade a estudos anteriores na área (ROSCOE-BESSA, 2000, 2006; BORGES, 2010 e AQUINO, 2011), de revisitálos, de atualizá-los e de tentar aplicá-los a outros contextos também justifica este estudo, especialmente a opção por trabalhar com cosméticos destinados ao público infantil, universo ainda inexplorado anteriormente e, ainda, a escolha do ambiente virtual de consumo, também sem sistematização prévia. 
Urge a necessidade de dar continuidade ao estudo da tradução de textos de consumo rápido e, especificamente, da tradução de rótulos, visto que as nuanças que envolvem a produção desses textos estão em constante processo de mudanças devido ao avanço das ciências, da legislação e à descoberta de novos caminhos a serem trilhados pela indústria da publicidade e, no caso deste estudo, pelos fabricantes de cosméticos infantis. Entretanto, em tempos de expansão do comércio eletrônico, há diversos outros produtos com os quais seria possível desenvolver uma pesquisa. Cosméticos infantis constituem apenas uma possibilidade.

Este estudo se insere, ainda, nos contextos da globalização e da localização, que se relacionam diretamente com a tradução, e constituem exemplo de ambos os fenômenos. Durante os dois últimos meses de pesquisa, as seguintes notícias foram destaque: "McDonald's lança batata frita com chocolate, a McChoco"”; "Coca-Cola troca slogan e anuncia mudanças após 7 anos"; "Polícia Civil apreende $\mathrm{R} \$ 400$ mil em cosméticos contrabandeados"4 (A polícia chegou aos produtos depois de receber denúncias sobre a falta de rótulos traduzidos em alguns dos cosméticos comercializados por grande rede de cosméticos no Distrito Federal); "OMS define novos parâmetros para alimentos processados que têm açúcar, sal ou gordura em excesso" ${ }^{5}$; e, por fim, "Carro batizado como Zica vai mudar de nome após epidemia"

\section{POR QUE RÓTULOS?}

Rótulos são textos que servem à identificação do conteúdo dos recipientes e, também, à comercialização de produtos. Ao desempenharem seu papel, entretanto, eles podem se constituir em registros históricos, em

\footnotetext{
${ }^{2}$ A notícia data de 20 de janeiro de 2016. Disponível em: http://extra.globo.com/noticias/economia/mcdonalds-lanca-batata-frita-com-chocolate-mcchoco18510375.html. Acesso em: 04 mar. 2016.

${ }^{3}$ A notícia data de 19 de janeiro de 2016. Disponível em: http://exame.abril.com.br/marketing/noticias/coca-cola-troca-slogan-e-anuncia-mudancas-apos7-anos. Acesso em: 04 mar. 2016.

${ }^{4}$ A notícia data de 20 de janeiro de 2016. Disponível em: http://www.metropoles.com/distritofederal/policia-civil-apreende-r-400-mil-em-cosmeticos-contrabandeados. Acesso em: 04 mar. 2016.

${ }^{5}$ A notícia data de 29 de fevereiro de 2016. Disponível em: https://nacoesunidas.org/omsdefine-novos-parametros-para-alimentos-processados-que-tem-acucar-sal-ou-gordura-emexcesso/. Acesso em: 04 mar. 2016.

${ }^{6}$ A notícia data de 02 de fevereiro de 2016. Disponível em: http://noticias.r7.com/carros/carrobatizado-como-zica-vai-mudar-de-nome-apos-epidemia-02022016. Acesso em: 04 mar. 2016.
} 
representantes de culturas globais e locais, e em difusores dos valores e dos ideais de uma sociedade, em uma determinada época, na medida em que revelam seus gostos e seus hábitos de consumo. Os rótulos, portanto, são um rico objeto para os Estudos da Tradução.

A escolha por trabalhar com rótulos se deve, também, à sua ampla circulação social, ao fato de eles proporcionarem situações de comunicação autênticas, e de apresentarem elementos verbais e não verbais que interagem entre si de modo sistematizado. Ademais, por se tratar de um gênero textual, o rótulo é dinâmico e está diretamente relacionado à sociedade em que se insere. Por conseguinte, ele se modifica, se adapta e se atualiza para melhor atender às necessidades desta e de outras sociedades nas quais são veiculados na era da globalização.

\section{ORGANIZAÇÃO DOS CAPÍTULOS}

O capítulo 1 é dedicado à apresentação dos pressupostos teóricos que fundamentam este estudo, passando pela globalização, pela localização, pela tradução-substituição e pela revisão da legislação. O capítulo 2 cuida da metodologia adotada ao longo da pesquisa desde sua fase preliminar.

No capítulo 3, o mercado de cosméticos infantis é apresentado, bem como o seu crescimento ao longo dos últimos anos, essencialmente no Brasil. O capítulo aborda a evolução da rotulagem, desde a embalagem como principal meio de informação ao consumidor no ato da compra até a oferta de produtos em meio virtual. Abordam-se, ainda, as mudanças na maneira de consumir e de se informar sobre o que consumir na era digital, destacando-se o papel do comércio eletrônico e da tradução nesse cenário de transformações.

O capítulo 4 se ocupa de um breve panorama sobre a tipologia textual em análise, assim como dados sobre a comercialização de cosméticos infantis e sobre o comércio eletrônico, tendo em vista que o conceito de rótulo nesta pesquisa foi expandido para abranger informações sobre cosméticos, disponibilizadas por seus fabricantes, diretamente em seus sites oficiais, e que 
contribuem para o convencimento do consumidor sobre sua compra, denominadas rótulos virtuais nesta pesquisa.

O capítulo 5 explora os papeis do rótulo como fonte de informação, como identidade do produto e como difusor de valores culturais, na medida em que o rótulo se tornou vendedor exclusivo em muitos ambientes comerciais e que, portanto, cabe ao tradutor observar todas as mensagens que esses textos transmitem, a fim de produzir traduções que permitam ao consumidor da comunidade meta decidir sobre sua compra de maneira segura e satisfatória, ou seja, para que os rótulos cumpram, para os consumidores de chegada, a mesma função que cumprem para os consumidores de partida.

O capítulo 6 se ocupa da análise de rótulos virtuais de cosméticos infantis fabricados no Brasil e aqui comercializados via lojas virtuais, da descrição dos principais elementos físicos e linguísticos dessa nova rotulagem, a fim de subsidiar a produção de traduções de rótulos virtuais de cosméticos infantis importados e comercializados no Brasil. Por fim, nesse capítulo são propostas traduções que subsidiem melhor os consumidores online no momento de suas compras, a partir de textos autênticos desse mesmo gênero textual.

São tecidas, então, as considerações finais sobre este estudo; são fornecidos os dados bibliográficos da pesquisa, bem como os anexos e apêndices aos quais o consulente poderá recorrer durante a leitura. 


\section{Referencial TeÓRICO}

Este capítulo é dedicado ao arcabouço teórico que subsidia esta pesquisa. A revisão passa pelos fenômenos da globalização e da localização, pela tradução-substituição, e pela legislação atinente aos dois principais grandes temas sobre os quais se desdobram este estudo: o comércio eletrônico e a rotulagem de cosméticos infantis.

\subsection{Globalização}

A globalização surge a partir das inovações científicas e tecnológicas, envolve mudanças nas esferas política e econômica essencialmente, e traz consigo impactos em outras áreas, inclusive nas línguas e na tradução. Barry Jones destaca que a globalização está longe de ser um fenômeno isolado. Ela não se constitui de uma série de mudanças conduzidas simplesmente por aspectos econômicos e tecnológicos; ao revés, para o autor, diversos outros aspectos conduzem a globalização e são por ela conduzidos (2000, p. 4).

De modo similar, Schäffner explana que, embora a globalização seja mais evidente nas áreas de economia e de marketing, ela influencia todos os ramos da vida. Para a autora, as inovações trazidas por esse fenômeno perpassam a política, a educação, os valores e, ainda, os hábitos cotidianos de cada indivíduo. Dessa forma, cozinhar e efetuar operações bancárias, por exemplo, não são mais atividades necessariamente desempenhadas como eram antes do advento da globalização (2000, p. 1).

As compras também foram impactadas pela globalização. Uma gama de produtos até pouco tempo inimagináveis está disponível ao consumidor. Do ponto de vista das transações comerciais, é cada vez mais comum ver empresas vendendo seus produtos além mar. Distâncias são encurtadas e barreiras legais e tributárias, por exemplo, são rompidas a fim de que produtos sejam vendidos em locais diferentes daqueles onde foram fabricados. Ao mesmo tempo, as empresas se tornam multinacionais, de forma que cada vez menos a procedência dos produtos pode ser associada a um único local.

Nesse novo cenário, a internet se tornou palco para diversas transações comerciais e para o compartilhamento de informações de um canto a outro do planeta em curtos períodos de tempo. A web se tornou um lugar 
onde pessoas se encontram para comprar e para vender mercadorias e, ainda, simplesmente para compartilhar informações sobre esses produtos. Esse espaço, agora, é qualificado como cyber: são sites de comércio eletrônico, redes sociais, aplicativos (apps) e e-mails. Transformaram-se, portanto, os modelos econômicos, o comportamento dos consumidores e o modo como eles buscam e prestam informações sobre os mais variados produtos.

As pessoas podem se comunicar, compartilhar conhecimento e experiências sem - no entanto - se conhecerem pessoalmente. Talvez nada saibam umas sobre as outras, entretanto, se assemelham pelo simples fato de estarem em um mesmo espaço virtual de discussão. Isso ocorre por que o cyberespaço ignora fronteiras físicas; ele transcende espaço e tempo de modo que as informações e as mensagens estão presentes em todo lugar e em todo momento. (SCHÄFFNER, 2000, p. 2)

A globalização ocorre nesse espaço, que proporciona aos consumidores acesso a produtos do mundo todo sem sair de suas casas e que desfaz as diferenças, tornando-os todos consumidores das mesmas marcas, das mesmas formas, dos mesmos sabores. Pym, entretanto, discorda desse modelo que associa a globalização diretamente à mera manipulação do mundo pelo McDonald's, pela Coca-Cola e pela Microsoft. O autor insiste que esse modelo que reduz o mundo globalizado à homogeneização cultural é deveras repetido (2006, p.746).

O generalismo também não atende à complexidade do fenômeno. Pym reconhece a existência de teorias que vinculam à globalização tudo que ocorre a nossa volta, "desde o estado do mercado até as condições da alma". Porém, o autor destaca que globalização não significa, por exemplo, todos os lugares produzindo todos os produtos ao mesmo tempo, ou seja, a produção não se tornou coletiva. Ao revés, o mundo globalizado se caracteriza pela existência de centros especializados de produção, o que leva à homogeneização da produção, do que é fabricado.

Uma das consequências dessa homogeneização é a convergência dos desejos de consumo em diversas áreas, essencialmente entretenimento,

\footnotetext{
7 "[...] from the state of markets to the condition of the soul". (PYM, 2006, p. 745, tradução minha)
} 
vestimenta e alimentação ${ }^{8}$. Nesse cenário, os consumidores globais passam a consumir produtos estrangeiros, o que, porém, é dificultado pela barreira das línguas. (ROSCOE-BESSA, AQUINO \& BORGES, 2014, p. 15) Para Pym, essa é uma situação nova em que a tradução é convidada a se manifestar e, portanto, que requer dos atores envolvidos no processo tradutório a capacidade de compreender e de responder a essas mudanças de conjuntura. O autor declara que "a globalização não é amiga e nem inimiga da tradução"9. Nesse mesmo sentido, Shiyab argumenta que a globalização impactou a vida de todos, inclusive a tradução enquanto profissão e a vida do tradutor que, diante das inovações tecnológicas e do surgimento de novos conceitos, têm de incorporar a globalização à sua vida cotidiana. (2010, p. 10)

Para Pym, há um aumento da demanda por traduções na era da globalização, em tempos de comunicação com custos reduzidos, de línguas comuns, de apenas uma lingua franca, do inglês. É o que o autor chama de "paradoxo da diversidade" (paradox diversity): o uso frequente da lingua franca na produção reduz a diversidade cultural, que, por sua vez, é mantida pela tradução, que pratica a diferença, e é essencial ao consumo em um mundo cujos pontos de produção e de consumo se encontram tão distantes um do outro. (2006, p. 747)

Este estudo se revela parte de um movimento contínuo de reflexão sobre trocas envolvidas entre esses pontos de produção e de consumo em um ambiente de intercâmbio de bens materiais, no caso a internet, um ícone atual de uma civilização de consumo internacional, que a cada dia se torna mais dependente de mecanismos que amenizem as barreiras linguísticas e que permitam a comunicação para o consumo.

\subsection{LOCALIZAÇÃO}

Esta seção é dedicada à localização, um dos fenômenos que decorrem da globalização. Na seção 1.2.1 serão fornecidos exemplos práticos da localização dos quais muitos não se dão conta, mas que fazem parte de uma grande cadeia de comercialização de produtos em âmbito global, da qual a

\footnotetext{
${ }^{8}$ FRAMSON, 2007, p. 45-46 apud ROSCOE-BESSA, AQUINO \& BORGES, 2014, p. 15.

${ }^{9}$ PYM, 2006, p. 745, tradução minha.
} 
tradução é um elo. A seção 1.2.2, por sua vez, apresentará subsídios teóricos sobre a localização.

\subsubsection{Paixão nacional: expresso ou coado ${ }^{10}$}

Na seção anterior, foi visto que a globalização não é um fenômeno que ocorre desvencilhado de outros, como a própria palavra não permitiria. Entretanto, além do fato de esse fenômeno gerar certa hegemonia dos desejos de consumo, de que outra maneira ele impacta, em termos práticos, os produtos que se adquire e de que se faz uso no dia a dia? De acordo com Gabriela Onofre, diretora de marketing da Procter \& Gamble do Brasil, "toda empresa global tem de ter um entendimento local, saber o que o consumidor gosta em cada lugar" (em entrevista à Revista Superinteressante). Portanto, em um mercado global, cada nicho apresenta suas especificidades e requer diferentes níveis de adaptabilidade para que os produtos sejam aceitos em diferentes locales ${ }^{11}$.

A KFC (Kentucky Fried Chicken) é um exemplo de marca que teve de se adequar ao mercado consumidor brasileiro para obter êxito em suas vendas. Enquanto nos Estados Unidos um balde repleto de frango frito vale por uma refeição, no Brasil as primeiras tentativas não foram bem-sucedidas. A empresa encontrou seu lugar no Brasil apenas quando acrescentou ao seu cardápio arroz e feijão. Além disso, no Brasil a marca perdeu a característica de o frango ser pego diretamente com as mãos; no Brasil, faz-se uso de talheres.

\footnotetext{
${ }^{10}$ Grande parte dos exemplos desta seção é baseada na reportagem: O Gosto Brasil Revista Superinteressante Disponível em: http://super.abril.com.br/comportamento/o-gosto-brasil; Acesso em: 02 mar. 2016. Quando não o for, as demais fontes serão citadas.

${ }^{11} \mathrm{O}$ termo "localização", quando passou a ser empregado pela indústria, correspondia à descrição generalizada de quaisquer alterações necessárias para adaptar o produto às necessidades de um determinado grupo de pessoas. Essa especificidade é muitas vezes referida como um locale, que significa tanto uma variedade linguística como um conjunto de preferências culturais (PYM, 2005, p. 2). Um locale também pode ser compreendido como um mercado específico, ou seja, um mercado para qual um produto foi localizado (ROSCOEBESSA, AQUINO \& BORGES, 2014, p.25). Segundo Cadieux e Esselink (2009 s/p), a indústria se refere a locale como um grupo de pessoas com um idioma em comum ou com as mesmas convenções culturais, mesmo que o grupo não esteja no mesmo local físico. Nesses casos, um locale pode ser entendido como um "local virtual", que se aproxima do conceito de cultura ou nação.
} 
A Starbucks conta com receitas exclusivas para o Brasil. O muffin de blueberry, opção icônica da rede para o café da manhã, teve de ser substituído por muffins de tomate seco e parmesão, visto que, pela manhã, os brasileiros preferem os salgados aos doces. Os pães de queijo foram acrescidos ao cardápio e são o item mais vendido quando se trata de salgados. Somente no Brasil há pães de queijo à venda na Starbucks; pela manhã, eles são acompanhados pelo café coado; já após o almoço, a preferência dos brasileiros é pelo café expresso.

No âmbito dos cuidados pessoais, o Brasil é o quarto maior mercado global de shampoo, porém é o primeiro de condicionadores, de tintura e de creme para alisar os cabelos. De acordo com Blaise Didillon, diretor de inovação da L'Oreal, "como a brasileira danifica muito o cabelo, tem uma rotina de tratamento muito mais complexa que em outros países" (em entrevista à Revista Superinteressante). Assim, aqui, a fabricante de cosméticos aposta em produtos com mais queratina e com agentes hidratantes, além de criar produtos como creme para pentear e reparadores de pontas para o mercado consumidor brasileiro.

Com relação aos desodorantes, no Brasil eles são feitos para ter um efeito mais duradouro, pois, de acordo com Didilon, "a relação com o odor é importante em qualquer país, mas no Brasil é muito mais crítica" (em entrevista à Revista Superinteressante). Ademais, o hábito de uso de roupas que deixam as axilas expostas levou ao desenvolvimento de desodorantes com agentes clareadores em suas fórmulas. Por fim, o sabonete líquido Lux teve sua fórmula modificada para produzir mais espuma, o que não se relaciona diretamente com a eficácia da limpeza. A gerente de marketing da marca, Gabriela Jacob destaca que: "a espuma é uma referência para a brasileira. Ela dá a sensação de que o sabão está limpando como deveria. Então fizemos um produto que fizesse espuma na quantidade, na velocidade e no tamanho certo para ela". Nesse mesmo sentido, é possível encontrar diversos outros exemplos, desde o chocolate nas famosas batatas fritas do McDonald's ao chocolate Kit Kat de saquê, tradicional bebida alcóolica, ambos comercializados apenas para 0 público japonês. 
Ao revés dessa tendência de adaptação às realidades locais, a Budweiser trocou a logo, a tipografia e o design de suas latas de cerveja, de modo a unificá-las em âmbito global. Excluíram-se, portanto, as variações de país para país antes presentes nas latas. ${ }^{12}$

Sabe-se que, do ponto de vista da produção, há diversas nuanças das quais 0 tradutor sequer tem conhecimento, de forma que a ele não compete intervir. Porém, do ponto de vista da rotulagem para o fornecimento de informações sobre o produto, é fundamental o conhecimento da legislação atinente à área com a qual se trabalha, no caso desta pesquisa, com cosméticos infantis.

\title{
1.2.2 A indústria da localização
}

\begin{abstract}
"Trata-se de um mundo em que se consomem frutas independente da estação do ano. Assim como uma fruta não é mais uma fruta desta ou daquela estação, um produto não é mais necessariamente oriundo de uma localização específica".
\end{abstract}

PYM, 2000

O mundo ao qual se refere Pym é marcado pela disponibilidade permanente não apenas de frutas, mas também de softwares, de games, de filmes, de músicas, de cosméticos e de um infinito de outros produtos. Vive-se a globalização dos hábitos, das culturas, dos valores, das pessoas e dos lugares. Vive-se o eu; vive-se o outro também; em que medida, porém, já não se sabe ao certo. A globalização, então, ultrapassa a esfera econômica e se destaca como um mundo de novos comportamentos e de novos conceitos.

Para Cronin (2003), entretanto, nem todas as partes do globo experimentarão a globalização ao mesmo tempo ou da mesma forma, visto que não existe um modelo único para esse fenômeno, e que seja adotado de modo indiscriminado pelas diferentes nações. Na verdade, cada país, cada região,

\footnotetext{
${ }^{12}$ Budweiser muda de logo e embalagem em nova fase. Disponível em: http://exame.abril.com.br/marketing/noticias/budweiser-muda-de-logo-e-embalagem-em-novafase\#2. Acesso em: 23 fev. 2016.
} 
cada cidade, cada locale apresenta características que não são universais; são locais. Esses aspectos são evidenciados diante da globalização; como em um movimento antropofágico, o global é digerido pelas comunidades locais, é reinterpretado e dá lugar a novos elementos, representantes das circunstâncias locais.

Nesse mesmo sentido, Pym (2006) alerta que é preciso cautela com o discurso de que tudo está a todo tempo em todo lugar. A globalização traz consigo a localização, um suspiro de individualidade em um mundo dito globalizado. Por meio de estratégias que preservam e, por vezes, evidenciam características locais, diversas multinacionais obtêm êxito na comercialização de seus produtos em diferentes países, como visto na seção anterior.

Desse modo, ao contrário do que se possa pensar, o mundo não se tornou uma comunidade tão reduzida a interesses comuns. De fato, o aumento das interações sociais, culturais, econômicas e políticas entre as organizações, - tanto em âmbito nacional quanto internacional - assim como entre os povos e os indivíduos, culmina na convergência dos desejos de consumo, mas não se pode presumir que os locales abdicam de suas características individuais em prol do consumo desenfreado do global, ou seja:

[...] a comunidade meta, embora inserida no mundo globalizado, tem perfil redefinido como um segmento único e fragmentado de um todo e consumidores de diferentes localidades querem consumir produtos estrangeiros que, entretanto, pareçam locais (ROSCOE-BESSA, AQUINO \& BORGES, 2014, p. 15).

Assim, pode-se afirmar que a globalização pressupõe a localização, visto que:

a dissolução de fronteiras nacionais, sociais e culturais leva a uma mistura de culturas, porém, ao mesmo tempo, há a retomada de conscientização do local, que termina por ser redefinido diante da globalização"

${ }^{13} 2007$, p. 46 apud ROSCOE-BESSA, AQUINO \& BORGES, 2014, p. 16 
Essa conscientização do local é destacada por Framson ${ }^{14}$ como uma tendência diante da globalização, e implica, nesse contexto, em fragmentação e em retribalização. As razões para esses outros movimentos, de acordo com a autora, são múltiplas, e estão diretamente relacionadas às diferenças culturais entre os mercados consumidores, que se reinventam, se rearranjam.

\subsubsection{A localização de apps ${ }^{15}$}

As primeiras iniciativas no sentido de reconhecer que preservar e, por vezes, evidenciar características locais na oferta de produtos a mercados estrangeiros poderia ser um caminho para a consolidação de empresas em âmbito global surgiram com hardwares e softwares durante a década de 1980. Os fabricantes perceberam que, se quisessem vender seus produtos em outros mercados, precisariam adaptá-los a novas realidades, visto que relacionamentos comerciais implicam não somente a troca de mercadorias em si, mas também de informações, de valores e de culturas, aspectos que não são necessariamente comercializáveis na mesma velocidade que produtos (ROTURIER, 2015, p. 5).

Do ponto de vista do ambiente de comercialização objeto desta pesquisa, a internet, os usuários estão passando cada vez mais tempo online e, por conseguinte, requerem que os conteúdos estejam disponíveis em uma língua que eles possam compreender. O estudo de Roturier sobre a localização de apps corrobora esta afirmação: o autor cita dados de uma pesquisa desenvolvida sobre as preferências linguísticas dos usuários ${ }^{16}$ da web na União Europeia, por meio da qual foi constatado que, enquanto alguns usuários se sentem confortáveis ao acessarem e lerem o conteúdo da rede em uma língua diferente da sua língua nativa, a maior parte dos internautas espera poder escolher uma língua para interagir no ambiente virtual (2015, p. 3).

\footnotetext{
${ }^{14}$ Ibidem, p. 15.

${ }^{15}$ Esta pesquisa adota a concepção de apps apresentada por Roturier: sites, programas de computador e aplicativos de celular, visto que são conteúdos digitais online criados por sistemas e que podem ser submetidos a alguma forma de localização com o intuito de alcançar o maior número possível de usuários (2015, p. 3). No âmbito do comércio eletrônico, objeto desta pesquisa, as lojas virtuais são consideradas apps, por serem sites.

${ }^{16}$ User language preferences, 2011.
} 
A partir desses dados, Roturier argumenta que as oportunidades online existem para as empresas que conseguem alcançar os usuários, apesar das barreiras linguísticas, ou seja, das empresas que usam a estratégia da localização ${ }^{17}$ (idem). De acordo com o autor, a localização na web já havia sido concebida como um ramo promissor na área de tradução há mais de uma década por O'Hagan e Ashworth ${ }^{18}$ e nunca foi tão relevante quanto nos dias de hoje.

Pode-se mencionar, no escopo desta pesquisa, embora não seja o seu foco, o uso das inovações na área de tecnologia da informação para localizar não apenas os produtos vendidos na web, mas também a própria experiência de compra online. Como exemplo, tem-se o perfil personalizado nos sites de comércio eletrônico. A partir do cadastro do usuário, de suas consultas e da realização de outras compras, é possível disponibilizar ao "e-consumidor" um espaço totalmente personalizado, individualmente localizado.

Como mencionado na subseção anterior, Roturier destaca que a legislação local desenvolve papel crucial na decisão sobre quando e como um conteúdo deve ser traduzido e/ou localizado. Nesse sentido, o autor destaca que:

a localização não se ocupa, necessariamente, da criação de um produto totalmente novo; às vezes é suficiente criar apenas alguns elementos suplementares ou substituir partes já traduzidas visando ao atendimento das expectativas locais ou ao encontro das normas e regulamentos locais ${ }^{19}$ (ROTURIER, 2015, p. 10, tradução minha).

A próxima seção é dedicada à tradução-substituição, especialmente no que concerne aos rótulos de produtos industrializados, contexto em que a comunidade meta requer a localização de elementos de rotulagem a partir de estratégias mencionadas acima, como a troca de partes já traduzidas por outras que melhor se adequam ao novo mercado consumidor.

\footnotetext{
${ }^{17}$ Ibidem.

${ }_{18}^{18} 2002$ apud Roturier, 2015.

19 "Localization is not about creating a full, new product from scratch, it is sometimes necessary to create some parts from scratch to supplement or replace existing translated sections, on order to meet local expectations or comply with local laws and regulations."
} 
"A tradução não lembra o original, mas só existe graças a ele."

ROSCOE-BesSA, 2010

Rótulos são textos híbridos e constituem um gênero bastante peculiar, que ora pode se aproximar do texto descritivo - como na especificação do produto - ora do texto científico, a exemplo da lista de ingredientes de um cosmético. Revela-se, de imediato, a necessidade de distintas posturas do tradutor de rótulos, visto que o texto perante o qual se encontra é "uma forma resultante de elementos múltiplos, sujeita, a todo tempo, a um número elevado de variáveis". (ROSCOE-BESSA, 2010, p. 10)

Essas variáveis envolvem elementos da Química, da Toxicologia, da Legislação - como será visto na seção 1.4 -, da Publicidade e do Marketing entre outras áreas do conhecimento humano que adornam esse cenário. Destarte, a familiarização com esses elementos se faz preliminar para o trabalho do tradutor que se envereda por esse caminho.

A tradução de rótulos traz consigo a necessidade de desvencilhamento da concepção de texto de partida como sagrado e inabalável. É necessário minar a ideia de que o "original" constitui uma porção de conteúdo e/ou de forma que deve permanecer intacta para que assim, e somente assim, o leitor tenha acesso ao texto de fato, à mensagem que se acredita que o autor quis transmitir. Nesse sentido, Roscoe-Bessa argumenta que:

Amiúde, o tradutor, na ilusória tentativa de manter um texto incólume, de não desvirtuá-lo e não adulterá-lo, procura a tradução que mais se aproxime do literal. No afã de manter o original numa redoma, iludese na procura por soluções que se aproximem do literal, linear, unívoco. (2010, p. 9)

O literal, o linear, o unívoco, entretanto, não costuma prover textos funcionais quando se trata do rótulo de um produto industrializado. Pelo 
contrário, textos que cumpram as principais funções da rotulagem - a serem exploradas no capítulo 5 -, e que atinjam o objetivo de vender um produto em um mercado consumidor meta requerem uma série de substituições nos níveis do micro e do macrotexto. Essas alterações, de modo geral, resultam em um texto com conteúdo excluído, acrescentado, substituído, porém funcionalmente equivalente. Percebe-se, portanto, que "[...] muitos procedimentos até então repudiados por tradutores passam a ser estratégias almejadas e legitimadas no processo tradutório"20.

O fato de essas estratégias serem repelidas por significativa parcela de tradutores leva Roscoe-Bessa a destacar que o trabalho com esse gênero textual envolve o "temor de violar um texto original em contraposição à premência de fazê-lo" (2006, p. 3). Nesse contexto, a tradução de rótulos de produtos industrializados demonstra-se deveras complexa, essencialmente, por exigir do tradutor que transgrida o original, que ultrapasse seus limites sem, contudo, se sentir traidor. São Jerônimo, padroeiro dos tradutores, já alertara sobre essa dificuldade de violação do original ao questionar:

\footnotetext{
Qual, de fato, o douto e mesmo o indouto que, desde que tiver nas mãos um exemplar, depois de o haver percorrido apenas uma vez, vendo que se acha em desacordo com o que está habituado a ler, não se ponha imediatamente a clamar que eu sou um sacrílego, um falsário, porque terei tido a audácia de acrescentar, substituir, corrigir alguma coisa nos antigos livros? ${ }^{21}$
}

Por meio do trabalho com esse gênero textual, o tradutor é levado à percepção de que o rótulo requer o distanciamento dos elementos de partida para o surgimento de um novo texto, independente em seu ambiente de consumo. Aqui, traduzir significa produzir um texto que funcione sozinho, que não esteja à sombra de um original, que não esteja à margem, mas no centro da relação de compra e venda. Na comunidade meta, o rótulo traduzido deve fazer com que o consumidor reconheça no produto que visa a adquirir os elementos que buscaria em um produto da indústria nacional, ou seja, o leitor-

\footnotetext{
${ }^{20}$ Ibidem, p. 10.

${ }^{21}$ Obras de São Jerônimo, edição dos Beneditinos, 1693, t. It. Col. 1425.
} 
consumidor deve ser guiado por caminho similar ao que trilharia caso estivesse diante de uma oferta em sua língua.

Afastar-se do texto de partida e dedicar-se à mensagem no universo de chegada não é, portanto, uma escolha do tradutor, mas uma necessidade, um pré-requisito para que o rótulo cumpra seus papeis de informar o consumidor sobre as principais características de um produto e de vendê-lo. O texto de partida, como o próprio nome sugere, é o ponto de onde se parte, não o ponto de chegada, de modo que o traduzir não pode ser representado por um círculo, e não se trata de um fenômeno reversível, pois o texto de chegada não carrega necessariamente as mesmas informações que o texto de partida.

A tradução se revela como um processo de comunicação que se retroalimenta: a própria existência do texto de partida depende da tradução que, embora não lembre o original, deve a ele a sua existência (ROSCOEBESSA, 2010, p. 20). Nessa linha, o tradutor tem importante papel para que o produto se mantenha vivo, por meio das substituições que a tradução, aqui, opera sobre ele, sobre o seu rótulo.

Por fim, Pessoa (2015, p. 234) observa que "o conceito 'traduçãosubstituição' vem sendo construído gradativamente, à medida que se demonstre sua aplicabilidade". Esta pesquisa é mais um contexto em que esse conceito se aplica, porém, de certo, surgirão novos estudos de gêneros textuais cuja tradução imprime a violação do original visando à efetivação do alcance de sua função.

\subsection{LEGISLAÇÃO REVISITADA}

Esta seção tem como objetivo revisar alguns conceitos elementares a este estudo, como o de cosméticos, de crianças e de rótulos (este último será abordado com mais detalhes no capítulo 4), e a legislação atinente às duas principais vertentes desta pesquisa: o comércio eletrônico e a rotulagem de cosméticos infantis. Do ponto de vista do comércio eletrônico, o item 1.4.4 é dedicado ao Código de Defesa do Consumidor (CDC) e ao seu projeto de 
atualização, enquanto o item 1.4.5 trata das orientações da ANVISA quanto ao comércio eletrônico de cosméticos.

\subsubsection{Sabonetes são cosméticos?}

A Resolução n. 211/2005 da Diretoria Colegiada da ANVISA define produtos de Higiene Pessoal, Cosméticos e Perfumes como:

[...] preparações constituídas por substâncias naturais ou sintéticas, de uso externo nas diversas partes do corpo humano, pele, sistema capilar, unhas, lábios, órgãos genitais externos, dentes e membranas mucosas da cavidade oral, com o objetivo exclusivo ou principal de limpá-los, perfumá-los, alterar sua aparência e ou corrigir odores corporais e/ou protegê-los ou mantê-los em bom estado.

Como destacado, um único item da Resolução conceitua produtos de higiene pessoal, cosméticos e perfumes, sem deixar clara a distinção entre cada uma dessas categorias. Poder-se-ia depreender, em uma primeira análise do trecho acima, que:

(a) produtos de higiene pessoal são aqueles cujo objetivo é limpar as diversas partes do corpo humano;

(b) perfumes são produtos que visam a perfumar o corpo; e

(c) cosméticos são os que têm como objetivo alterar a aparência das diversas parte do corpo humano.

Nesse caso, restam dúvidas sobre a correção dos odores corporais, sobre a proteção do corpo e sobre a sua manutenção em bom estado.

Destaque-se que um creme dental poderia ser considerado um produto de higiene pessoal; ao mesmo tempo, ele também serve para proteger e manter os dentes em bom estado. Então, por um lado, seria possível afirmar que produtos de higiene pessoal são aqueles que limpam, protegem e mantêm em bom estado as diversas partes do corpo humano?

Por outro lado, é fato que os fotoprotetores protegem a pele, como o próprio nome indica. Porém, se seguida a lógica do parágrafo anterior, não 
parece tão evidente que eles se enquadram na categoria "produtos de higiene pessoal" por protegerem uma parte do corpo humano como fazem os cremes dentais. Os fotoprotetores seriam cosméticos, então? A certeza é de que perfumes não são. Hidratantes para a pele constituem outro exemplo. De certo, eles protegem a pele e a mantêm em bom estado. São produtos de higiene pessoal, então? Ou seriam cosméticos para a maior parte dos usuários?

Percebe-se, portanto, que a diferença entre produtos de higiene pessoal e cosméticos não parece muito clara. Embora em alguns casos essa distinção possa ser evidente, em outros pode gerar conflitos no que concerne à legislação vigente e áreas afins como a tradução.

Já a Resolução n.- 15/2015, que dispõe sobre os requisitos técnicos para a concessão de registro de produtos de higiene pessoal, cosméticos e perfumes infantis, por meio de seu Anexo I, separa os produtos infantis nas três categorias: produtos de higiene pessoal, cosméticos e perfumes. Assim, embora não haja definições claras para cada categoria, existe um rol de produtos infantis que se subdividem entre os três grupos (vide anexo $\mathrm{A}, \mathrm{p}$. 137). Segundo o regramento em comento, óleos corporais infantis são enquadrados na categoria de higiene pessoal, produtos para prevenir assaduras são cosméticos e as águas de colônia são perfumes.

Entretanto, apesar da categorização proposta pela ANVISA, deve-se admitir que há razões além das estritamente técnicas apresentadas que motivam consumidores a adquirir produtos de higiene pessoal e cosméticos. Um batom pode ser considerado um cosmético quando se pensa que sua principal função seja alterar a aparência dos lábios. Entretanto, quando o mesmo batom é aplicado para amenizar os efeitos de lábios ressecados, ou para evitar a exposição excessiva aos raios solares, está-se fazendo uso desse produto principalmente como cosmético? Ainda nesse sentido, quando se escolhe um shampoo essencialmente pela sua fragrância, está-se adquirindo meramente um produto de higiene pessoal?

Percebe-se que, embora haja uma definição técnica do que sejam produtos de higiene pessoal, cosméticos e perfumes, e tenha sido publicada uma Resolução mais atual da ANVISA que categoriza os produtos infantis 
entre "de higiene pessoal, cosméticos e perfumes", há fatores culturais que nem sempre permitem divisão tão estanque. Levando esses aspectos em consideração, esta pesquisa utilizará, doravante, a denominação "cosmético" para se referir a produtos das três categorias, por considerar que - no Brasil essa é a categoria mais ampla entre as três discutidas.

\subsubsection{Quem é criança?}

De acordo com o Art. $2^{\circ}$ do Estatuto da Criança e do Adolescente (ECA), criança é a pessoa até 12 anos de idade incompletos. Essa definição é objetiva e trata de conceito legal. Digiácomo e Digiácomo (2013, p. 4) destacam que, de certo, outras ciências, como a psicologia e a pedagogia podem adotar parâmetros etários diversos, e que as normas internacionais consideram crianças todas as pessoas, indistintamente, com idade inferior a dezoito anos.

A ANVISA, por meio da Resolução $n .-15 / 2015$, citada na seção anterior, considera público infantil crianças cuja idade esteja compreendida entre zero e doze anos incompletos - assim como o ECA - de forma que as disposições do normativo da Agência se aplicam a todos os produtos comercializados visando a esse público.

Há, ainda, produtos fabricados para o público infantil e utilizados por adultos, assim como existem aqueles que são desenvolvidos para adultos, porém não prejudiciais às crianças. É O caso dos cosméticos indicados concomitantemente aos públicos infantil e adulto, e que estão previstos na referida Resolução. Nesses casos, há requisitos específicos a serem atendidos pelos cosméticos adultos nas fases de comprovação de suas propriedades e na de rotulagem.

A indústria cosmética, entretanto, não fabrica produtos tão uniformes para pessoas que se encontram em uma faixa etária tão extensa quanto de $0 \mathrm{a}$ 12 anos. Assim, o regulamento da ANVISA desconsidera as diversas fases da infância e estipula regras comuns a todos os cosméticos fabricados. 
De certo, há diferenças entre produtos desenvolvidos para recémnascidos e bebês. Até quanto tempo de vida se é considerado bebê? Um bebê de 5 meses faz uso dos mesmos produtos que um bebê de 10 meses? Crianças de 7 anos provavelmente não tomam banho com sabonete líquido da cabeça aos pés, talvez elas prefiram o shampoo, o condicionador e o sabonete do Frozen. Ainda nesse sentido, meninas de 11 anos podem querer cabelos sem frizz.

Diante dessa diversidade, esta pesquisa buscou considerar, especialmente para a fase de análise, produtos infantis variados. Entretanto, em alguns momentos, foi dada atenção especial aos produtos para bebês (a partir da designação do próprio fabricante), tendo em vista justamente a facilidade de agrupá-los, de fazer generalizações sobre eles e até de propor traduções.

\subsubsection{O que são rótulos, afinal?}

Como visto de maneira abreviada na introdução, esta pesquisa se propõe a estudar a oferta de cosméticos infantis em lojas virtuais brasileiras, diante do crescimento da venda de produtos pela internet. Essa oferta constitui, para os fins deste estudo, uma nova modalidade de rótulo, que será abordada com detalhes no capítulo 4.

Assim, para fins didáticos, até o capítulo 4 , o conceito de rótulo que o leitor deve ter em mente é de um conjunto de informações presentes nas embalagens físicas dos produtos e que serve para caracterizá-los.

\subsubsection{O Código de Defesa do Consumidor}

"O Brasil mudou de 1990 até nossos dias, mudou o sistema jurídico, mudou a economia, a democratização do crédito, temos um novo Código Civil e a Internet é um novo meio de as pessoas se relacionarem. Nada mais natural que o Direito se adapte a essa nova realidade, baseado na diretriz de reforço da efetividade e da confiança no Código de Defesa do Consumidor (CDC), que conduzem à maior segurança jurídica 
para todos os atores no mercado de consumo e fortalecem o sistema nacional de defesa do consumidor."22

O Brasil foi precursor na criação de um diploma legal para proteger as relações de compra e venda. O consumidor que o CDC, datado dos anos 90, ampara não pode, porém, ser considerado o mesmo consumidor hodierno. Para aquele, o acesso à web no Brasil ainda era restrito. Para este, o comércio eletrônico é uma realidade. As relações de consumo mudaram; os consumidores, por conseguinte, também.

Diante dessa mudança de paradigma, surge o debate em torno da aplicação do CDC à nova modalidade de comércio e, ainda, da necessidade de atualização dessa lei para que ampare - de modo mais específico - os direitos desse "e-consumidor", como justifica Benjamin:

Promulgado em 1990, o Código de Defesa do Consumidor (CDC) colocou o Brasil na vanguarda dos países que já haviam legislado a matéria e ainda hoje é considerado modelo. [...] Depois de 20 anos de vigência, o CDC não deixa, como qualquer lei, de ser prisioneiro de seu tempo. Apesar de normas visionárias, não havia como prever em 1990 o crescimento exponencial das técnicas de contratação à distância, as transformações tecnológicas e o crescente comércio eletrônico de consumo,[...]. Esta nova realidade brasileira coloca a necessidade de aperfeiçoar os mecanismos existentes de apoio aos consumidores, especialmente os preventivos, com o intuito de reduzir conflitos $[\ldots]$.

[...] O objeto é evoluir (nunca retroceder) a defesa do consumidor e, respeitando a sua estrutura principiológica, tratar estes novos e essenciais temas no corpo do Código, a evitar guetos normativos dissociados do espírito protetivo do CDC. (Relatório do Projeto de Lei do Senado n. ${ }^{\circ} 281 / 2012$ )

Destarte, tramita na Câmara dos Deputados ${ }^{23}$ o Projeto de Lei do Senado $n .^{\circ}$ 281/2012, que visa à atualização do CDC para regulamentar as compras realizadas pela internet. O PLS propõe a criação de uma nova seção no Código para tratar apenas do comércio eletrônico, visando, essencialmente,

\footnotetext{
${ }^{22}$ Trecho extraído do texto introdutório do Relatório do Senador Ricardo Ferraço sobre os PLS no 281 e 283, de 2012, de autoria do Senador José Sarney, que alteram a Lei no 8.078, de 11 de setembro de 1990 (Código de Defesa do Consumidor), para aperfeiçoar o referido diploma legal e dispor sobre o comércio eletrônico, o crédito ao consumidor e a prevenção do superendividamento.

${ }^{23}$ A última consulta ao andamento do referido PLS no site www2.camara.leg.br foi realizada em 26 de fevereiro de 2016, às 09h57.
} 
à diminuição da assimetria de informações prestadas ao consumidor em ambiente virtual ao prever que:

Art. 44-B. Sem prejuízo do disposto neste Código, os sítios eletrônicos ou demais meios eletrônicos utilizados para oferta ou conclusão de contrato de consumo devem disponibilizar, em local de destaque e de fácil visualização, dentre outras, as seguintes informações:

$[\ldots]$

V - características essenciais do produto ou do serviço, incluídos os riscos à saúde e à segurança dos consumidores;

[...]. (PLS n. $.281 / 2012)$ (grifo do autor)

Há, entretanto, quem advogue que a aquisição de bens e/ou de serviços via web não descaracteriza a relação de consumo e, portanto, não justifica a alteração do CDC, visto que os seus ditames se estendem à modalidade virtual de comércio. É o que defende Carvalho (2012), in verbis:

Não há qualquer necessidade de regulamentar a relação de consumo no e-commerce, vez que não difere no seu conceito estrutural da relação de consumo, não trata o consumidor de forma diferenciada pelo modo da aquisição do produto ou um serviço, mas sim pela posição de consumidor.

Entretanto, apesar de se posicionar contra a criação de dispositivo próprio ao comércio eletrônico no CDC, o autor reconhece que o consumidor virtual deve ter seus direitos tutelados pelo Estado "já que é impossível se quantificar quantos possíveis consumidores estarão sendo lesados por publicidade enganosa e outros tantos abusos cometidos também na forma virtual". (CARVALHO, 2012) Ainda nesse sentido, o autor recomenda que: "[...] seja dado [ao comércio eletrônico] um tratamento tal qual às compras realizadas de modo não presencial $[\ldots]^{\prime 24}$.

Corroborando este entendimento, Maia \& Damasceno (2013) asseveram que:

\footnotetext{
${ }^{24}$ Ibidem.
} 
Não há dúvidas quanto à aplicação do CDC - lei 8.078/90 - nas vendas pela internet realizadas à pessoa física ou jurídica que adquire ou utiliza produto ou serviço como destinatário final. Ocorre que, apesar da existência da referida legislação, que pode, sim, ser aplicada às relações de consumo, foi criado um debate acerca do correto emprego das normas já previstas no CDC e da necessidade de criação de regras que melhor se adequassem ao ambiente virtual.

Seguindo o mesmo entendimento, para a Fundação de Proteção e Defesa do Consumidor de São Paulo (Procon/SP), no comércio eletrônico:

[o]s produtos e serviços devem ser oferecidos com informações corretas, claras, precisas e ostensivas sobre as suas características, preço, garantia, prazo de validade, dados do fabricante e sobre eventuais riscos que possam apresentar à saúde e à segurança do consumidor (2014, p. 11).

Ademais, para o referido órgão de proteção aos direitos do consumidor, a ausência dessas informações, enaltecidas de modo precursor pelo CDC, chega a configurar propaganda enganosa, in verbis:

Toda publicidade que contenha informações falsas sobre o produto ou serviço ou que seja capaz de confundir o consumidor sobre suas características pode ser considerada como publicidade enganosa. Também é enganosa a publicidade que não informa dados essenciais. $^{25}$

$\mathrm{Na}$ direção apontada por Carvalho (2012), por Maia \& Damasceno (2013) e pelo Procon/SP, qual seja - de aplicação do CDC ao comércio eletrônico - e, conforme destacado por Roscoe-Bessa (2000), os artigos 6을 inciso III, e 31 do CDC são de extrema valia para pesquisas cujo objeto seja a tradução de rótulos, por preconizarem que:

Art. 6 São direitos básicos do consumidor:

III - a informação adequada e clara sobre os diferentes produtos e serviços, com especificação correta de quantidade, características, composição, qualidade, tributos incidentes e preço, bem como sobre os riscos que apresentem;

${ }^{25}$ Ibidem, p. 12. 
Art. 31. A oferta e apresentação de produtos ou serviços devem assegurar informações corretas, claras, precisas, ostensivas e em língua portuguesa sobre suas características, qualidades, quantidade, composição, preço, garantia, prazos de validade e origem, entre outros dados, bem como sobre os riscos que apresentam à saúde e segurança dos consumidores. (grifos meus).

Considerando os aspectos mencionados até aqui, depreende-se que a oferta de produtos importados na web deve estar em língua portuguesa, além de seguir os critérios de clareza e de precisão, entre outros.

Vale mencionar o Decreto $n .^{\circ}$ 7.962, de 15 de março de 2013, que regulamenta o CDC e traz normas específicas para o comércio eletrônico. Sobre esse regramento, Maia \& Damasceno (2013) opinam que ele "se mostrou extremamente genérico, deixando de abordar de forma mais específica pontos controversos", além de não esclarecer aspectos que já eram controversos no próprio CDC e que deixaram de ser corretamente regulamentados.

A partir do cenário delineado acima, é necessário tecer algumas observações práticas:

(a) é provável que o PLS n. 281/2012 seja aprovado, de modo que o CDC seja modernizado em breve, e preveja que as lojas virtuais promovam a oferta de seus produtos e de seus serviços com informações essenciais sobre eles, incluindo elementos sobre os riscos à saúde do consumidor e à sua segurança;

(b) enquanto o PLS ainda está em tramitação no Congresso Nacional, os ditames contidos no CDC são aplicáveis ao comércio eletrônico. Entre eles, destaca-se nesta pesquisa a orientação de que a oferta de produtos seja em língua portuguesa, inclusive a de importados, o que indica necessidade de tradução.

\subsubsection{A legislação sanitária}

A Resolução da Diretoria Colegiada da ANVISA (RDC) que detalha os requisitos técnicos à concessão de registro de cosméticos infantis pela Agência foi atualizada recentemente. Trata-se da RDC n. 15, de 24 de abril de 2015, 
retificada em 6 de maio do mesmo ano. Esse regramento foi resultado de consulta pública realizada pela Agência, que propôs a atualização dos requisitos em comento.

Entre os destaques da Resolução proveniente dessa consulta estão: o estabelecimento de critérios como faixa etária, a formulação dos produtos, os testes de segurança e as advertências de rotulagem. Além de apresentar os dizeres de rotulagem especificados para cada tipo de produto, em forma de anexo, a proposta mantém a determinação da Resolução anterior (n.$38 / 2001$ ), que foi revogada, de que figuras, imagens ou desenhos constantes dos rótulos, das embalagens e de material de divulgação não devem induzir sua utilização por crianças de idade inferior à indicada.

Essas orientações são de extrema valia para o trabalho dos tradutores no que diz respeito ao acréscimo de informações como advertências na tradução de rótulos de produtos importados e que sejam provenientes de países cuja legislação seja divergente sobre esses aspectos. Ademais, embora se saiba que nem sempre tradutores têm influência sobre as figuras, as imagens e os desenhos constantes dos rótulos, de certo a presença ou a ausência desses elementos impacta seu trabalho, considerando que o rótulo virtual é um hipertexto com partes que interagem entre si.

\subsubsection{O Click Saudável}

A proposta de modernização do $\mathrm{CDC}$, como apresentada na seção 1.1.4, não é a única iniciativa do Estado no sentido de proteger o consumidor em face à revolução causada pelas plataformas de comércio eletrônico. Muito pouco se encontrou, entretanto, de orientações e/ou normas substanciais da ANVISA a respeito dessa modalidade de comércio no que concerne aos cosméticos, inclusive infantis.

De acordo com matéria publicada em seu site, a ANVISA esclarece que: 
No Brasil, a venda de cosméticos, alimentos, produtos de limpeza e produtos para saúde pode ser feita pela internet. Entretanto, é necessário que estes produtos estejam regularizados na ANVISA e atendam os requisitos de segurança e eficácia específicos de cada categoria ${ }^{26}$

Apesar de alertar para o fato de que produtos comercializados em meio virtual também devem estar registrados no órgão, a Agência não faz qualquer menção à oferta dos produtos em si por meio da web nesse trecho.

A ação da Agência e do Ministério da Saúde é no sentido de prover informações genéricas ao consumidor que the permitam se conscientizar melhor antes de adquirir produtos pela internet. Nesse sentido, foi criado o Click Saudável, projeto que objetiva "auxiliar o internauta a encontrar informações mais confiáveis sobre alguns dos produtos que consome."27

Essa iniciativa é resultado de uma parceria firmada entre a ANVISA e o Mercado Livre - maior site de e-commerce no Brasil -, e prevê a inclusão de 12 milhões de anúncios publicitários com informações de utilidade pública para orientar os consumidores que procuram, no Mercado Livre, produtos cuja regulamentação é de competência da Agência. Em contrapartida, o site de comércio virtual "vai fornecer à ANVISA os dados dos responsáveis por publicidades irregulares e uma ferramenta de busca e remoção desses anúncios". 28

De certo, esse movimento no sentido de educar o cidadão para o consumo é relevante diante de tantas opções referentes a lojas virtuais, a produtos e a procedência do que se pode consumir via click. Entretanto, acredita-se que esses alertas não substituem informações claras, precisas e ostensivas sobre as características de um produto, e que medidas repressivas

\footnotetext{
${ }^{26}$ Anvisa e MercadoLivre firmam parceria e lançam o Click Saudável. Disponível em: http://portal.anvisa.gov.br/wps/content/anvisa+portal/anvisa/sala+de+imprensa/menu++noticias+anos/2015/anvisa+e+mercadolivre+firmam+parceria+e+lancam+o+click+saudavel. Acesso em: 26 fev. 2016. ${ }_{27}$ Ibidem.

${ }^{28}$ Anvisa e MercadoLivre firmam parceria e lançam o Click Saudável. Disponível em: http://portal.anvisa.gov.br/wps/content/anvisa+portal/anvisa/sala+de+imprensa/menu++noticias+anos/2015/anvisa+e+mercadolivre+firmam+parceria+e+lancam+o+click+saudavel. Acesso em: 26 fev. 2016.
} 
às publicidades irregulares podem prevenir acidentes de consumo, mas nem sempre contribuem com a escolha do consumidor.

O projeto foi inaugurado em abril de 2015 em Brasília e, em sua fase inicial, conta com uma página na internet: www.clicksaudavel.gov.br. O objetivo desse espaço é reunir informações que orientem a população sobre a compra de produtos em sites de comércio eletrônico. Acessando a página, encontra-se, de fato, uma série de artigos sobre produtos sujeitos à vigilância sanitária. São exemplos: "Agrotóxicos na amamentação: benefício supera riscos"; "Evite o consumo de alimentos à base de Goji berry"; e "O pH da água pode influenciar na saúde dos consumidores?".

Navegando pelo site, a aba "cosméticos" traz duas publicações, uma de extremo interesse desta pesquisa: "De olho nos cosméticos infantis: saiba como proteger seu filho de reações indesejadas". Ao clicar no link, porém, o conteúdo não está disponível. Tentou-se contato com a ANVISA por meio de correio eletrônico para comunicar a impossibilidade de acesso ao material, entretanto, não houve resposta.

Conforme mencionado previamente, esses textos - embora educativos - apresentam apenas informações gerais sobre produtos cuja fabricação e comercialização estão sujeitas ao Sistema de Vigilância Sanitária. Restam, porém, dúvidas quanto à eficácia do clicksaudavel.gov.br do ponto de vista da promoção da segurança do consumidor, na medida em que o site não proporciona dados mais específicos sobre produtos.

Como saber, então, se um sabonete contém uma substância à qual se é alérgico? Como se informar sobre o modo de uso de um produto desconhecido? Sabe-se, obviamente, que esse papel deve ser desempenhado pelos rótulos, e que nenhum site poderia cobrir toda a oferta de produtos. Considera-se, de fato, que o projeto em comento seja pertinente à educação para um consumo mais consciente. Por essa razão, acredita-se que o Click Saudável seria um ótimo mecanismo de empoderamento do consumidor e de promoção da cidadania; em caráter complementar, porém, não como o principal aliado do Governo na proteção à saúde do "e-consumidor". 


\section{Metodologia}

Em Roscoe-Bessa (2003), é destacado o caráter precursor do estudo da tradução de rótulos e a sua complexidade, que pode ser atribuída, primordialmente, às interfaces da rotulagem com a legislação, com a Química, com a Farmácia e com a Toxicologia, entre outros campos de estudo. No prefácio da obra, a pesquisadora chama a atenção para a ausência de hipóteses com as quais se trabalhar, em função do aspecto inovador da pesquisa, o que torna a tarefa ainda mais laboriosa, na medida em que os questionamentos e os objetos de estudo surgem conforme ele se desenvolve, delineando o caminho a ser percorrido pelo pesquisador da tradução de textos de consumo rápido.

\subsection{CATEGORIA}

Situação similar à apresentada no parágrafo anterior se delineia para este estudo, que surgiu da percepção de que o aumento exponencial de compras pela internet nos últimos anos provocou, de certo, mudanças na maneira como os consumidores se informam sobre o que adquirem, inclusive quando se trata da oferta de produtos importados e comercializados no Brasil via web, foco desta pesquisa. Este estudo nasce, então, a partir de uma analogia feita por esta pesquisadora entre a oferta de um produto em uma loja virtual e os rótulos de produtos adquiridos em lojas físicas e, portanto, afixados nas embalagens dos produtos que são retirados das prateleiras, analisados e levados pelos consumidores para suas casas no ato da compra.

A partir dessa primeira analogia, surgiram questionamentos como: em que medida as informações prestadas na oferta de um produto comercializado na internet se aproximam daquelas veiculadas nos rótulos físicos? Que tipos de dizeres são transmitidos ao consumidor que adquire um produto importado em um site de comércio eletrônico no Brasil? Essas informações são suficientes para garantir-Ihe uma compra segura? À medida que se buscava respostas a essas perguntas iniciais, surgiam diversas outras ainda mais complexas e passíveis de serem investigadas e que, por muitas vezes, redesenhavam 0 
caminho do estudo, o que o caracteriza como reflexivo. Esses questionamentos perpassam toda a pesquisa.

O gênero textual aqui explorado surge no comércio eletrônico, diante da consolidação da internet como espaço de compra e de venda de mercadorias em âmbito global. Não foram encontrados estudos prévios sobre esse gênero, de forma que se fez necessária uma reflexão sobre ele, bem como a sua descrição, que se justifica também pelo recorte do estudo para o universo infantil.

Assim, este estudo se classifica como qualitativo: trata-se, em sua essência, de uma análise descritiva de um gênero textual, embora em alguns momentos possa pender para os métodos quantitativos de pesquisa, de modo que ambos os métodos aqui se complementam. Como são muitas as possibilidades de conteúdo de um rótulo, tanto no âmbito do texto partida quanto na tradução, as inferências são feitas por amostragem, visto que não é viável incluir todas essas opções em uma única pesquisa. No capítulo 6, na seção destinada à aplicação, será possível visualizar exemplos de quão ricas são as possibilidades de tradução de um rótulo.

Do ponto de vista da tradução, esta pesquisa se fundamenta, principalmente, em estudos anteriores na área de rótulos (ROSCOE-BESSA, 2000, 2006; BORGES, 2010; AQUINO, 2011) e, quando possível, aplicam-se essas pesquisas, pois, como será abordado, o surgimento de novos gêneros textuais no ambiente virtual não passa de uma adaptação dos já existentes.

Em relação a essas pesquisas anteriores, o escopo deste estudo é ainda mais reduzido, na medida em que considera apenas cosméticos infantis, embora não somente esses produtos suscitem exigência do consumidor com relação às informações que the são prestadas no momento da compra.

\subsection{ETAPAS DE PESQUISA}

Diante da inexistência de literatura específica sobre a rotulagem de cosméticos infantis em ambientes virtuais, o primeiro momento deste estudo foi 
dedicado à observação de sites de fabricantes nacionais de cosméticos infantis, visando à caracterização das ofertas de produtos na web e à verificação da similaridade entre as informações prestadas pelos fabricantes nesse ambiente e aquelas prestadas por meio dos rótulos físicos. Foi realizada, em seguida, uma análise qualitativa constituída de uma investigação visual crítica, detalhada e criteriosa dos sites selecionados, na qual foram avaliadas informações referentes à escolha e ao uso do produto por parte do consumidor, elementos que são decisivos no ato da compra.

De certo, como citado em oportunidade anterior, essa etapa de observação e de diagnóstico foi conduzida pelos estudos anteriores na área de tradução de rótulos. Mais detalhes a respeito da seleção desses sites, das marcas e dos produtos analisados são fornecidos no capítulo 6 .

Em seguida, foram consultadas diversas áreas como legislação e publicidade, o que resultou na posterior descrição e no levantamento de aspectos subjacentes à matéria em estudo, e que poderiam ser relevantes para a obtenção da tradução da oferta de produtos infantis na internet.

Por fim, buscou-se aplicar os elementos observados e apresentar propostas de tradução para produtos cosméticos infantis, apresentando-se, ainda, observações sobre as escolhas desta pesquisadora/tradutora. 
Este capítulo destina-se à apresentação do mercado de cosméticos infantis, produtos elegidos para este estudo, e seu crescimento ao longo dos últimos anos especialmente no Brasil, fator que - de certa forma - justifica a opção pelo trabalho com esse grupo. São abordados alguns fatores que podem contribuir para o aumento do consumo de produtos dessa categoria no Brasil e no mundo, o que perpassa as trocas comerciais entre diferentes países na era da globalização.

Nesse contexto de compra e venda, a seção 3.2 apresenta, de maneira breve, a evolução da embalagem como principal meio de informação ao consumidor no momento da compra - por meio do rótulo -, chegando ao ambiente virtual, onde não há mais contato com a embalagem no momento da compra. Abordam-se, ainda, as mudanças na maneira de consumir e de se informar sobre o que consumir na era digital, destacando-se o papel do comércio eletrônico nesse cenário de transformações.

\subsection{O MERCADO DE COSMÉTICOS INFANTIS}

O Brasil detém um dos maiores mercados globais de cosméticos, inclusive infantis. Dados da Associação Brasileira da Indústria de Higiene Pessoal, Perfumaria e Cosméticos (ABIHPEC) demonstram que o país ocupa a terceira posição no ranking dos mercados mundiais de Higiene Pessoal, Perfumaria e Cosméticos, representando $9,4 \%$ do consumo mundial dessa categoria. No âmbito dos produtos infantis, o mercado brasileiro sobe para a segunda posição ${ }^{29}$.

Nos últimos 19 anos, a Indústria Brasileira de Higiene Pessoal, Perfumaria e Cosméticos apresentou aumento médio de 10\% ao ano, valor considerado excelente pela ABIHPEC. A Associação elenca, entre vários outros fatores para esse incremento: $O$ acesso das classes $D$ e $E$ aos produtos,

\footnotetext{
${ }^{29}$ Os dados desta seção foram obtidos, majoritariamente, no "Panorama do Setor de HPPC de 2015" da Associação Brasileira da Indústria de Higiene Pessoal, Perfumaria e Cosméticos.
} 
devido ao aumento de renda; o consumo de artigos com maior valor agregado pelos novos integrantes da classe C; o crescimento da participação da mulher brasileira no mercado de trabalho; a utilização de tecnologia de ponta e o consequente aumento da produtividade (o que favoreceu os preços praticados pelo setor); o aumento da expectativa de vida, o que traz a necessidade de conservar uma impressão de juventude e, por fim, o lançamento constante de produtos.

Ressalte-se o surgimento incessante de novos cosméticos para atender menos às necessidades e mais às expectativas de mercado que, ao serem alimentadas no cotidiano, tornam-se necessidades reais de consumo. As vitrines das lojas cada dia mais atraentes, as prateleiras dos supermercados mais e mais abarrotadas de opções e o surgimento diário de novos sites de compras podem estar refletindo esse apelo pelo consumo.

No que concerne aos produtos infantis, foco deste estudo, o Instituto de Pesquisa Euromonitor ${ }^{30}$ indicou, para o mercado de higiene e de cuidados corporais com bebês, um salto de $R \$ 3,6$ para $R \$ 5,7$ bilhões em cinco anos. Ademais, estima-se que, até 2019 , o segmento fature cerca de $R \$ 8,4$ bilhões.

É evidente que os fatores elencados pela ABIHPEC e citados acima contribuem para a posição de destaque do Brasil também com relação aos produtos infantis. Entretanto, considera-se pertinente pontuar outras possíveis razões para esse cenário, por exemplo, a redução da taxa de fecundidade ${ }^{31}$. Nesse aspecto, é relevante mencionar que a média de filhos por brasileira era de 6,16 filhos em 1940 e chegou a ser de 6,28 em 1960. Entretanto, os dados de 2010 revelam uma queda brusca para 1,9 filho. $^{32}$

De certa forma, pode-se associar a redução do número de filhos por mulher à possibilidade de maior dedicação financeira às necessidades e às expectativas de consumo dos pais com relação a seus filhos. Tamanha

\footnotetext{
${ }^{30} \mathrm{O}$ Instituto de Pesquisa Euromonitor é responsável pelo levantamento do consumo de cosméticos no mundo. Para mais informações: <http://www.euromonitor.com/>.

${ }^{31} \mathrm{~A}$ taxa de fecundidade indica quantos filhos, em média, tem a mulher brasileira. Fonte: Instituto Brasileiro de Geografia e Estatística (IBGE). Para mais informações: $<$ www.ibge.gov.br>.

${ }^{32}$ Dados do IBGE, disponíveis em: <http://7a12.ibge.gov.br/vamos-conhecer-o-brasil/nossopovo/nupcialidade-e-fecundidade.html>; Acesso em: $11 \mathrm{dez} .2015$.
} 
mudança no perfil da sociedade brasileira permite que as crianças tenham mais roupas, mais brinquedos, mais acessórios e, também, mais produtos de higiene e de beleza, alguns há bem pouco tempo inimagináveis como colônia para os cabelos, lenços umedecidos, gel pós-sol e spray para os cabelos.

Outro aspecto que merece ser considerado é a expansão do turismo internacional ao longo das seis últimas décadas. Em 1950, foram registradas 25 milhões de chegadas de turistas internacionais (visitantes que pernoitam) e, desde então, esse número vem crescendo, atingindo 1.133 milhões em 2014. ${ }^{3334}$ As Américas registraram o maior crescimento em relação às demais regiões do mundo em 2014, com destaques para a América do Norte, responsável por dois terços das chegadas internacionais no continente Americano, e para os Estados Unidos, principal destino da região e segundo maior do mundo, atrás apenas da França.

Quanto às viagens internacionais, a Europa é a região que mais emite turistas para outras localidades. Vale salientar, entretanto, que, com o aumento dos níveis de renda, diversas economias emergentes experimentaram um crescimento elevado no setor nos últimos anos. O Brasil, sem dúvidas, representa uma dessas economias, tendo em vista ocupar a décima posição no ranking mundial de países cujos viajantes mais gastam com turismo internacional.

Ainda nessa perspectiva, o Ministério do Turismo informa que os Estados Unidos são o destino internacional favorito dos brasileiros. Há grande destaque para Orlando e Miami, cidades que mais receberam brasileiros em 2014, e que são tradicionais pelos centros de compras e pelos parques temáticos. ${ }^{35}$ Nesse contexto, cabe mencionar o crescimento do número de

\footnotetext{
${ }^{33}$ Esses números são definidos em âmbito internacional, de forma que não se destacam países de modo individual. No caso das chegadas, por exemplo, os números expressam a quantidade de pessoas provenientes de quaisquer lugares do mundo que pernoitam em quaisquer outros lugares. O exemplo apresentado não revela a realidade de um único país, mas do mundo.

${ }^{34}$ Os dados relacionados ao turismo internacional foram obtidos no Panorama OMT del turismo internacional, edición 2015. Disponível em: <http://www.eunwto.org/doi/pdf/10.18111/9789284416875>; Acesso em: 11 dez. 2015.

${ }^{35}$ EUA são o destino favorito de turistas brasileiros. Portal Brasil. Turismo. Disponível em: $<$ http://www.brasil.gov.br/turismo/2015/06/eua-sao-o-destino-favorito-de-turistas-brasileiros>; Acesso em: 11 dez. 2015.
} 
brasileiros que vão a essas cidades montar os enxovais de seus filhos em busca de ampla variedade de modelos e marcas (GOLDENBERG, 2014).

Os Estados Unidos, por sua vez, são o segundo país que mais emite turistas ao Brasil $^{36}$. Em 2014, devido principalmente à Copa do Mundo, 656 mil turistas norte-americanos visitaram o país. Nessa dinâmica de emissão e de recepção de turistas entre Brasil e Estados Unidos, quantas trocas culturais e comerciais não são estabelecidas?

De maneira objetiva, quando eu visito o país do outro, levo comigo diversos itens, inclusive cosméticos e produtos de higiene pessoal, mas também trago a nova fragrância que conheci no estrangeiro, o hidratante ainda não desenvolvido em meu país e a linha de maquiagem de uma marca desconhecida, que encontrei na viagem. O outro, por sua vez, ao visitar meu país, também traz consigo os seus produtos da mesma natureza e leva outros por variadas razões.

Revelam-se, portanto, novos contatos e, como consequência, outras possibilidades e experiências. Diante de um mercado em potencial, que agora tem acesso a novos produtos e a novas marcas, as indústrias do setor têm se preocupado em lançar produtos dos mais variados tipos, enquanto outras buscam ingressar no mercado de cosméticos infantis.

Nesse cenário de trocas entre diferentes países, o comércio eletrônico (e-commerce) é destaque. Hoje, por meio de poucos cliques, compram-se produtos de algum lugar do outro lado do mundo. Ou será do mesmo lado do mundo? $\mathrm{Na}$ era do e-commerce não se sabe exatamente onde estão as mercadorias que são adquiridas. O AliExpress, por exemplo, está presente em 190 países conectando compradores e vendedores em uma loja que não possui estoque.

\subsection{DA MERCEARIA À INTERNET: O BOOM DO E-COMMERCE}

O que leva o consumidor a eleger um produto diante de tantas outras opções? O nome? A marca? O fabricante? O preço? O país de origem?

\footnotetext{
${ }^{36}$ Destinos turísticos brasileiros são divulgados nos EUA. Turismo. Portal do Brasil. Turismo. Disponível em: <http://www.brasil.gov.br/turismo/2015/12/destinos-turisticosbrasileiros-sao-divulgados-nos-eua>; Acesso em: $11 \mathrm{dez} .2015$.
} 
Diferentes estudos nas áreas de comunicação, marketing, economia e outros campos do conhecimento já se dedicaram e ainda se dedicam às respostas para essas perguntas. De certo, o somatório desses e de outros aspectos determinam 0 ato da compra. Assim, nessa cadeia de produção, cada elemento desempenha papel fundamental no produto final, que é a venda.

A embalagem, em conjunto com o rótulo, se tornou o vendedor silencioso. Ela pode levar um produto a ser escolhido em um universo de diversos outros, na medida em que o diferencia dos demais e que, quando bem apresentada, tem o poder de despertar o impulso da compra. Ao ser atraído pelo visual da embalagem, o consumidor toma o produto em suas mãos, confere o seu rótulo e decide pela aquisição ou não.

De acordo com pesquisa realizada pela Associação Brasileira de Embalagem (ABRE), um produto concorre com cerca de 30 mil outros itens em um supermercado. Nesse cenário de ampla concorrência e de bombardeio de informações, a participação da embalagem no processo de decisão sobre a aquisição de um produto é crucial:

é a embalagem que deve transmitir, em apenas 3 segundos, a qualidade do produto, os seus diferenciais e cativar o consumidor para pegá-lo em sua mão e colocá-lo em seu carrinho de compras. ${ }^{37}$

Diferentes grupos de consumidores, entretanto, são influenciados por mecanismos e estratégias diversas, de forma que devem ser abordados de maneiras distintas:

os homens levam em consideração, prioritariamente, elementos racionais como quantidade, preço, forma de uso do produto. Já as mulheres são mais sucessíveis aos apelos emocionais, onde faz-se necessário trabalhar apelos subjetivos no design da embalagem. O público infantil é atraído por cores e elementos lúdicos, enquanto que idosos buscam facilidade de leitura e de abertura ou manuseio. ${ }^{38}$

\footnotetext{
${ }^{37}$ PELLEGRINO, L. A embalagem. Disponível em: <http://www.abre.org.br/setor/apresentacaodo-setor/a-embalagem/>. Acesso em: 30 abr. 2015.

${ }^{38}$ loc. cit.
} 
Assim como esses estratos são levados à aquisição de um produto por razões diversas, cada país também tem seus padrões, que devem ser observados, por exemplo, no momento da exportação. Pellegrino destaca que "a linguagem subliminar de uma embalagem é altamente influenciada por aspectos regionais e culturais, sendo essencial entender estes aspectos e trabalhá-los, por meio de seu design, nas embalagens". ${ }^{39}$

Ainda de acordo com Pellegrino, "a embalagem é considerada o reflexo de uma sociedade, de sua cultura, hábitos, e do seu estágio de desenvolvimento econômico, social e ambiental". ${ }^{40} \mathrm{Um}$ exemplo disso é o critério de funcionalidade, referente aos ideais de conveniência no preparo, no manuseio e na segurança de produtos. Esse quesito caracteriza, essencialmente, países desenvolvidos, na medida em que a sociedade os apresenta bem estabelecidos.

A embalagem, no entanto, nem sempre apresentou esse caráter decisivo no momento da compra, tendo em vista que surgiu como mero recipiente para bens de consumo. O papel da embalagem foi, por bastante tempo, apenas proteger o conteúdo. Impulsionados pela Segunda Grande Guerra, os supermercados deram origem ao autosserviço e o consumidor, a partir de então, passou a ter autonomia para escolher produtos nas prateleiras.

A partir desse momento, as embalagens tiveram de ser reinventadas, e passaram a ser qualificadas pelos rótulos, visto que o caráter meramente recipiente foi substituído pelo informativo. Os rótulos, por sua vez, assumiram a tarefa de comercializar mercadorias em âmbitos nacional e internacional (ROSCOE-BESSA; AQUINO; BORGES, 2014, p. 11).

Embalagens e rótulos assumiram, então, o papel do vendedor, que presta informações úteis a respeito dos produtos e, ao mesmo tempo, persuade sobre a compra. Tornaram-se, portanto, fundamentais para a vida moderna, por desempenharem importante papel na economia e no comportamento da sociedade de consumo.

\footnotetext{
${ }^{39}$ loc. cit.

${ }^{40}$ loc. cit.
} 
As mudanças na maneira de consumir e de se informar sobre o que consumir, porém, não pararam por aí. Quanto ao modo, há até bem pouco tempo, o consumidor se satisfazia buscando um ponto de venda (aquele de sua confiança ou preferência), onde conhecia as mercadorias por meio do vendedor, ou até mesmo do rótulo, e dirigia-se ao caixa para efetuar o pagamento; assim, realizava sua compra.

Essa realidade, entretanto, vem mudando desde 1987, quando o uso comercial da internet foi liberado nos Estados Unidos (DOMENICI, 2014), e o acesso à rede passou a permitir a realização de compras, que hoje prescindem da interação humana como antes concebida. Passados alguns anos e respeitado o tempo necessário para que o comércio eletrônico aqui se estabelecesse e se consolidasse, é possível dizer que a internet modificou 0 perfil de consumo também no Brasil, aumentando em 250\% o hábito de compras online nos últimos 5 anos.

De acordo com o Serviço Brasileiro de Apoio às Micro e Pequenas Empresas (SEBRAE), nos últimos 13 anos, o número de consumidores do ecommerce passou de um milhão em 2001 para 61,5 milhões em 2014, sendo que hoje há mais de 100 milhões de internautas. ${ }^{41}$ Ainda de acordo com o SEBRAE, os produtos mais buscados pelos consumidores digitais brasileiros são as roupas e os acessórios, seguidos dos cosméticos.

Esse incremento deve-se, essencialmente, à inclusão digital das classes $C, D$ e $E$, acompanhada do crescimento do acesso à banda larga (popularização da internet); à facilidade de acesso aos cartões de crédito, ao crescimento do poder de consumo e, ainda, ao aumento na venda de smartphones, notebooks e tablets. No ranking do comércio eletrônico, o Brasil, com $4,3 \%$ de participação no mercado mundial, lidera as compras na América Latina e há expectativa de que, em 2015, tenha ultrapassado a França, o Reino Unido e a Alemanha, chegando a ocupar a $4^{\underline{a}}$ posição no cenário global. ${ }^{42}$

\footnotetext{
${ }^{41}$ SERVIÇO BRASILEIRO DE APOIO ÀS MICRO E PEQUENAS EMPRESAS. O que você precisa saber sobre o comércio eletrônico. Disponível em: http://www.sebrae.com.br/sites/PortalSebrae/sebraeaz/O-que-voc\%C3\%AA-precisa-sabersobre-com\%C3\%A9rcio-eletr\%C3\%B4nico. Acesso em: 14 dez. 2015.

${ }^{42}$ loc. cit.
} 
Sobre a maneira de se informar a respeito do que consumir, pode-se afirmar que também houve reinvenção. Antes de comprar um produto, os consumidores digitais querem mais informações a respeito do que estão prestes a adquirir. Assim, eles pesquisam o produto na própria rede, tanto em sites especializados quanto no endereço, agora eletrônico, do próprio fabricante.

Ademais, a internet proporciona aos consumidores a troca de experiências e a busca de opiniões de outras pessoas sobre aquele mesmo produto em blogs, em chats e, ainda, em redes sociais. Estudo da Mintel, agência de inteligência de mercado no mundo, revela que o consumidor brasileiro apresenta elevado grau de envolvimento com as redes sociais. De acordo com essa mesma pesquisa, quase 3 em cada 10 pessoas ( $\cong 28 \%$ ) disseram que visitam sites de varejistas motivadas por anúncios no Facebook, tendência que vem crescendo entre os consumidores mais jovens.

Nesse cenário, os consumidores digitais comparam, tanto em âmbito nacional quanto internacional, produtos, ofertas, preços e variedade daquilo que buscam consumir. Compara-se, por exemplo, o preço de uma camisa entre São Paulo e Brasília, o que pode ser decisivo para a aquisição do produto em uma das cidades ou, simplesmente, para a não aquisição. Da mesma maneira, conhece-se um novo produto, ainda não fabricado no Brasil, via internet e, agora, é possível adquiri-lo.

Assim, à medida que mais pessoas se conectam à internet todos os dias para buscar e compartilhar informações sobre produtos e serviços com outros consumidores espalhados pelo mundo, é possível afirmar que surge uma nova maneira de se informar sobre o que se consome. Dentro dessa nova realidade, cada consumidor se torna um vendedor virtual, na medida em que tece elogios, críticas, sugestões, reclamações e comentários que podem ser decisivos sobre o bem que se pretende adquirir ou sobre o serviço que se deseja contratar. 
Dessa maneira, assim como a embalagem teve de ser reinventada para substituir o vendedor, muitos fabricantes e comerciantes tiveram de reinventar suas lojas, que passaram a ser virtuais, e, nessa perspectiva, também tiveram necessidade de encontrar mecanismos que lhes permitam ter voz nas informações que são prestadas sobre os produtos comercializados, visto que, no ambiente de comércio virtual, a embalagem não é mais tocável e nem o rótulo é legível.

Nesse novo espaço de consumo, as informações prestadas devem ser semelhantes àquelas encontradas pelos consumidores quando vão, por exemplo, ao supermercado e manuseiam um produto em busca de suas características antes de adquiri-lo. Isso porque o consumidor precisa se certificar de que se trata do mesmo produto com o qual já está acostumado, tendo em vista os transtornos que a compra equivocada pode gerar, inclusive custos adicionais referentes ao frete e à troca de mercadorias.

É igualmente importante que o tipo de caracterização feita do produto nos rótulos físicos seja preservado na área destinada à sua oferta na internet. Assim, no caso de produtos desconhecidos, o consumidor poderá se informar sobre as características que considera elementares antes de adquiri-los pela internet e experimentá-los, ideia que será mais bem explorada no próximo capítulo. 


\section{POR UMA NOVA DEFINIÇÃO DE RÓTULOS}

O capítulo anterior dedicou-se a apresentar dados sobre o mercado de cosméticos infantis, em potencial desenvolvimento no Brasil, e sobre o comércio eletrônico, focos desta pesquisa. Foi visto que, em era de expansão do e-commerce, não são mais as embalagens dos produtos que decidem a compra, na medida em que se tornaram intangíveis, assim como os rótulos, por estarem sempre a elas fixados.

$\mathrm{Na}$ loja virtual, o consumidor passou a obter resenhas de outros consumidores, que se tornaram vendedores digitais ou "contra vendedores" em muitos casos. Entretanto, não se pode concluir que nesse ambiente de compra e venda os consumidores prescindem de informações consideradas essenciais pelos órgãos reguladores e que só podem ser fornecidas pelos fabricantes e pelos importadores.

Nesse sentido, destacou-se que fabricantes e comerciantes devem cuidar para que seus espaços virtuais subsidiem os consumidores com informações similares àquelas encontradas nos rótulos físicos dos produtos, a serem mais exploradas no próximo capítulo. Assim, esta pesquisa se preocupa com esse aspecto e tem como foco as informações prestadas sobre os cosméticos infantis nas lojas virtuais.

Considerou-se pertinente refletir, neste capítulo, a respeito da definição de rótulo. Acredita-se que a importância dele para a segurança do consumidor já é amplamente reconhecida. Entretanto, a concepção de rótulo considerada senso comum não satisfaz esta pesquisa, que busca estender o conceito de rótulos para o ambiente virtual, na medida em que o comércio eletrônico cresce exponencialmente, e que os rótulos físicos não são mais a principal fonte de informação dos consumidores. Diante dessa nova realidade, novos mecanismos de oferta, de publicidade e de informações sobre os produtos precisam ser desenvolvidos, regulados e traduzidos. 


\subsection{BREVE INTRODUÇÃO}

O homem sempre encontrou mecanismos para identificar o conteúdo dos frascos de produtos acondicionados. A princípio, os rótulos eram manuscritos e passaram a ser impressos - como os concebemos hoje somente com o advento da imprensa no século XV.

Por volta de 1798, na Bavária, Alois Senefelder criou o princípio da litografia, o que possibilitou a impressão em cores e conferiu aos rótulos alto grau de sedução chamando a atenção dos consumidores. Essa técnica foi utilizada no século XIX de maneira extensiva para imprimir diversos tipos de documentos, inclusive rótulos, e foi substituída pela impressão offset no século $\mathrm{XX}$.

Por meio dessa sucinta introdução, percebe-se que, embora os rótulos tenham sido, de início, manuscritos, e tenham se modificado do ponto de vista das tecnologias de impressão ao longo da história, eles sempre foram afixados nos frascos. A concepção que se criou de rótulo, portanto, é de um material físico, tangível e, muitas vezes, destacável da embalagem.

Como visto no capítulo 3, a mudança de paradigma da comercialização via balcão para o autosserviço impactou de forma direta a embalagem e a rotulagem, proporcionando ao rótulo posição de destaque na venda. Assim, é possível afirmar que novas formas de comercializar produtos modificam 0 modo de ofertá-los, de prestar informações sobre eles, de identificá-los e de manifestar valores culturais, ou seja, modificam os rótulos, que realizam todas essas funções, como será visto no próximo capítulo.

\subsection{DEFINIÇÃO DE RÓTULOS}

A ANVISA destaca o caráter físico da rotulagem, abordado na seção anterior, ao definir rótulo como:

Identificação impressa ou litografada, bem como dizeres pintados ou gravados, decalco sob pressão, aplicados diretamente sobre 
recipientes, vasilhames, invólucros, envoltórios ou qualquer outro protetor das embalagens (Anvisa, RDC n.ำ79/2000, grifos meus).

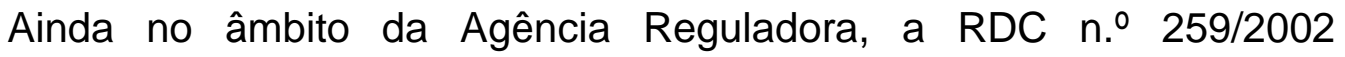
apresenta o seguinte conceito de rotulagem:

É toda inscrição, legenda, imagem ou toda matéria descritiva ou gráfica, escrita, impressa, estampada, gravada, gravada em relevo ou litografada ou colada sobre a embalagem [...] (grifo meu).

De certo, esse aspecto destacado pela Agência é de suma importância. $\mathrm{Na}$ medida em que rótulos são elementos essenciais e obrigatórios para a comercialização de produtos no país, o Órgão estabelece o que é considerado rótulo do ponto de vista material.

Entretanto, restringem-se as acepções de rótulo e de rotulagem a elementos, essencialmente dizeres e imagens que, independente do método ou do material, vêm na própria embalagem dos produtos, principalmente para identificá-los. O rótulo é, portanto, parte integrante do recipiente que contém o produto, é um elemento palpável.

A questão se torna delicada quando, diante do crescimento do comércio eletrônico, rótulos permanecem sendo considerados apenas identificações impressas ou litografadas em recipientes. Se o rótulo é um vendedor exclusivo, se ele é o principal, senão o único, canal de comunicação entre fabricante e consumidor, onde está o rótulo na era em que se compra online? Ao mesmo tempo, se, para a venda de produtos importados no país, é necessária a etiqueta de tradução, também física, onde colá-la na loja virtual?

Além dos questionamentos levantados acima, ambas as definições não levam em consideração o que é dito sobre os produtos e nem a maneira de dizê-lo, o que é feito pela Anvisa por meio de resoluções esparsas e pelo Código de Defesa do Consumidor, o que dificulta o trabalho dos atores envolvidos nos processos de comercialização de produtos no país, tradutores de rótulos inclusive. Ademais, a Agência ignora o aspecto sociocultural dos rótulos. 
Essa dimensão é apresentada por Martins e Borghi (2007), que não se atêm aos aspectos materiais do rótulo, mas à importância e à legitimidade deles como elementos que apresentam características históricas, culturais e sociais ao defini-los como:

registros históricos, que representam a cultura, os valores e os ideais de uma sociedade, numa determinada época, revelando os gostos, os costumes e as tendências de consumo, evidenciados, pelo padrão artístico utilizado e pelos apelos de consumo momentâneos (p.9).

Para os autores, portanto, o rótulo é mais do que simples matéria descritiva colada sobre a embalagem. Ele é visto como um canal de compartilhamento da história, da cultura, dos valores e dos ideais de uma sociedade de consumo em espaço e tempo determinados. Mais detalhes sobre como o conteúdo dos rótulos corrobora a definição de Martins e Borghi serão apresentados no próximo capítulo.

A partir da análise das três definições acima, conclui-se que é premente propor um novo conceito para rótulo, que reúna tanto a dimensão material quanto a imaterial dos rótulos. Esse novo conceito deve contemplar, também, o ambiente virtual, local onde os consumidores passam a buscar informações sobre os produtos que desejam adquirir, pois - diante dessa nova realidade em discussão - não é mais possível tomar os produtos em suas mãos e analisar seus rótulos.

Nesse sentido, a definição proposta por esta pesquisa, que vai ao encontro das necessidades elencadas acima, é:

rótulos são registros, sistematizados segundo determinados critérios e condicionados por aspectos socioculturais, de itens que identificam - conteúdo das embalagens, informam os consumidores e comercializam produtos, assegurando que o consumidor decida sobre sua compra e faça uso adequado do produto durante toda sua vida útil, e que estão disponíveis ao consumidor em meio físico e/ou virtual.

Essa definição aqui proposta incorpora pontos importantes, quais sejam:

(a) A predeterminação dos registros: os elementos registrados nos rótulos são predefinidos, regulados e fiscalizados pela Anvisa. Vale 
ressaltar que essa característica prevalece nos rótulos físicos. Entretanto, embora não seja a Anvisa responsável pela fiscalização dos produtos vendidos na internet, é possível afirmar que as informações disponíveis nas lojas virtuais também são selecionadas de acordo com critérios previamente estabelecidos;

(b) Os condicionantes socioculturais dos registros: embora grande parte das informações disponíveis seja técnica, é perceptível a existência de história, de cultura e de valores sociais nos rótulos dos produtos comercializados, o que vai ao encontro da definição apresentada por Martins e Borghi (2007).

(c) A decisão do consumidor e o uso adequado do produto: no ato da compra, o papel principal da rotulagem é fornecer ao consumidor informações suficientes, de maneira evidente, para que ele decida sobre a aquisição de um produto de maneira segura. Nesse sentido, o Código de Defesa do Consumidor preconiza que:

\begin{abstract}
a oferta e apresentação de produtos ou serviços devem assegurar informações corretas, claras, precisas, ostensivas e em língua portuguesa sobre suas características, qualidades, quantidade, composição, preço, garantia, prazos de validade e origem, entre outros dados, bem como sobre os riscos que apresentam à saúde e segurança dos consumidores (CDC, Art. 31, 1990).
\end{abstract}

Ademais, é necessário destacar que informações sobre o uso de um produto, sua composição, sua data de fabricação e seu prazo de validade, bem como advertências sobre acondicionamento e manuseio devem estar sempre disponíveis ao consumidor via rotulagem até o produto ser descartado, a fim de garantir o uso adequado dentro de seu prazo de validade e/ou ao longo de sua vida útil ${ }^{43}$.

(d) A apresentação em meio físico ou virtual: a definição sugerida possibilita que os rótulos sejam físicos, impressos ou litografados, e

\footnotetext{
${ }^{43}$ A diferença entre prazo de validade e vida útil será abordada no capítulo 5 .
} 
afixados nos recipientes; ou virtuais, disponibilizados nas lojas virtuais, com a mesma função de subsidiar as compras.

\title{
4.3. ROTULAGEM NA ERA DIGITAL: OS RÓTULOS VIRTUAIS
}

Na seção anterior, foi proposta uma definição para rótulos com vistas a reunir elementos materiais e imateriais e, ainda, a abranger o conteúdo disponibilizado sobre os produtos cuja oferta ocorre em ambiente virtual. Considera-se necessário, entretanto, que mais informações sejam fornecidas a fim de caracterizar o que será chamado, de agora em diante, de rótulo virtual (Figura 1). Assim, de forma mais específica:

\begin{abstract}
Rótulos virtuais são quaisquer informações disponibilizadas por fabricantes e/ou comerciantes online, diretamente em seus sites oficiais e/ou em suas lojas virtuais, cuja finalidade seja identificar 0 conteúdo das embalagens, informar o consumidor a respeito das principais características do produto e ajudá-lo a decidir sobre a compra.
\end{abstract}

Figura 1 - Exemplo de rótulo virtual de cosmético infantil

JOHNSON'S ${ }^{\circledR}$ baby HIGIAPELE ${ }^{\circledR}$ Glicerinado

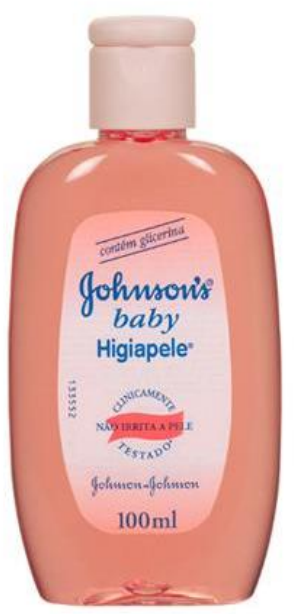

VISĀO GERAL DO PRODUTO

COMO E ONDE USAR

INGREDIENTES

SEGURANÇA

Como e Onde Usar

Embeba um chumaço de algodão com JOHNSON'S ${ }^{\circledR}$ baby

HIGIAPELE ${ }^{\circledR}$ com glicerina e passe suavemente na pele do bebê até limpá-la completamente. Não é necessário diluir, nem enxaguar após o uso. Atenção: Manter fora do alcance das crianças. Somente para uso externo. Conservar em local fresco e seco.

Indicação: uso infantil e adulto.

Fonte: www.johnsonsbaby.com.br

Destaquem-se aqui os "fabricantes e/ou comerciantes online". Há casos em que não é possível finalizar a venda nos sites oficiais dos fabricantes. Não há como incluir produtos no carrinho ou na cesta virtuais, e nem como efetuar o pagamento online, ou seja, a finalidade do site não é a venda direta. 
É o caso da Johnson \& Johnson no Brasil, cujo site www.johnsonsbaby.com.br não permite realizar compras. Entretanto, esta pesquisa parte do princípio de que o objetivo final desses fabricantes é a venda de seus produtos, mesmo que em uma loja virtual ou, até mesmo, em uma loja física e reconhece que, lato sensu, fabricantes são comerciantes online, porém, os diferencia para fins didáticos.

Em outros casos, o fabricante vende o produto em seu site oficial. Paradoxalmente, é o caso da Johnson \& Johnson nos Estados Unidos. Por meio do endereço eletrônico www.johnsonsbaby.com é possível, além de se informar de maneira oficial sobre o produto, adquiri-lo. Nesses casos, o fabricante é um comerciante online stricto sensu.

Há, ainda, as lojas virtuais multimarcas. Nesse caso, a principal finalidade da loja é a venda direta: "lojas virtuais são sites de e-commerce, em que o cliente visualiza e escolhe seu produto, coloca no carrinho de compras e passa no caixa para realizar o pagamento, em um processo totalmente online" (SEBRAE, 2011). Os comerciantes online aos quais se refere a definição de rótulo virtual acima enquadram-se nesta categoria.

Por fim, há usuários das redes sociais e de aplicativos de troca de mensagens que utilizam seus perfis para comercializar produtos online ou acabam criando perfis com essa finalidade. Embora alguns aspectos dessas transações possam diferir daquelas realizadas diretamente em lojas virtuais, o comércio via Facebook, Instagram e Whatsapp pode ser considerado uma modalidade de e-commerce (Figura 2). 
Figura 2 - Exemplo de rótulo virtual de cosmético infantil em rede social (Instagram)

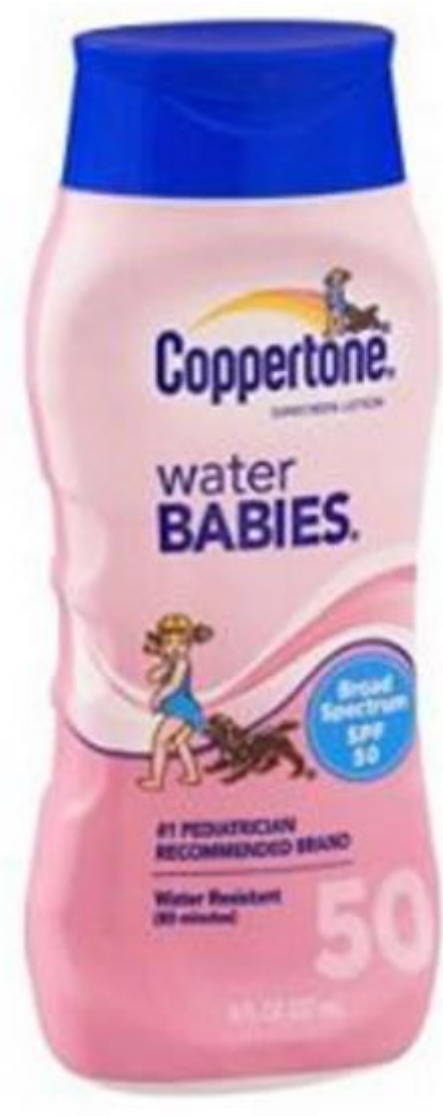

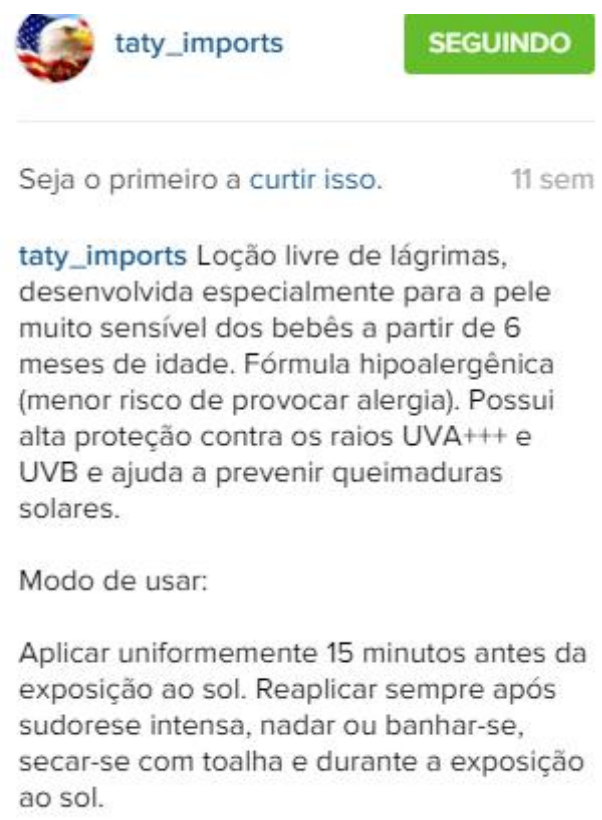

Adicione um comentário..

Fonte: www.instagram.com.br/taty_imports

Cabe esclarecer que as "informações disponibilizadas por fabricantes e/ou comerciantes online" não se restringem àquelas por eles elaboradas. Dessa maneira, o rótulo virtual inclui as resenhas ${ }^{44}$ dos compradores que compartilham sua experiência na web, tanto com relação ao serviço prestado pela loja virtual quanto ao produto adquirido em si. Mais detalhes sobre elementos dos rótulos virtuais serão vistos no capítulo 6, na seção destinada à análise dos rótulos virtuais.

4.4 RÓTULOS VIRTUAIS: A INOVAÇÃO TECNOLÓGICA E O SURGIMENTO DE UM NOVO GÊNERO TEXTUAL

No capítulo 3, foi visto que a possibilidade de uso da internet para fins comerciais e o amplo acesso à rede revolucionaram os processos de compra e

\footnotetext{
${ }^{44}$ Também conhecidas como avaliações ou comentários.
} 
venda de maneira incontestável e irreversível. Mudou-se a maneira de consumir e, ainda, de se informar sobre o que se consome; mudou-se a maneira de interagir com o fabricante, com o vendedor e com o próprio produto; mudou-se a forma de ofertar um produto, de pagá-lo e, por fim, de recebê-lo.

Esse espaço digital revolucionou, então, o contexto comunicativo das relações sociais de compra e de venda; o ser humano, por sua vez, teve necessidade de novos mecanismos de interação social, que passou a ocorrer em um ciberespaço. Foi justamente nesse contexto que o rótulo virtual se desenvolveu, por demanda da sociedade de consumo moderna, sobretudo, diante da inovação tecnológica.

Vale salientar que - nesse cenário de transformações - pode ser evidenciado, à contramão do apresentado no parágrafo anterior, o desaparecimento de gêneros textuais, que podem cair em desuso e serem substituídos por outros gêneros. O foco desta pesquisa, entretanto, é o surgimento de um gênero textual - o rótulo virtual - que passou a existir em concomitância com aquele a partir do qual surgiu - o rótulo físico. Ambos servem para que os falantes atinjam os mesmos objetivos, ou objetivos similares.

O fato é que, embora continuem existindo, os rótulos físicos não mais servem às relações sociais de compra e venda que o comércio eletrônico estabeleceu na internet. Daí, então, a necessidade de perceber o rótulo virtual como um novo gênero e sobre ele refletir, sempre lançando olhares sobre os rótulos físicos, pois conforme Marcuschi:

Nem sempre temos algo essencialmente novo, mas derivado como, por exemplo, os chats surgindo como uma forma de conversação por meios eletrônicos, ou os blogs surgindo dos diários de bordo. Este estado de coisas mostra a dinamicidade dos gêneros e sua facilidade de adaptação inclusive na materialidade linguística. Assim, hoje se reconhece que não é apenas a forma stricto sensu que resolve a questão do gênero e sim sua funcionalidade e organicidade. (2005, p. 23, grifos do autor) 
O novo gênero, então, traz consigo características daquele a partir do qual se desenvolveu, na medida em que servem a propósitos similares e se organizam de maneira semelhante, fazendo prevalecer as funções de informar, de identificar e de comercializar produtos, essenciais aos rótulos. Ainda nesse sentido, Marcuschi (2005) observa que o surgimento de novos gêneros textuais no ambiente virtual não passa de uma adaptação dos já existentes, que foram incorporados às tecnologias encontradas atualmente pela sociedade.

Assim como as interações sociais não são estanques e imutáveis, mas dinâmicas e sujeitas a variações constantes, podemos reconhecer que os gêneros também variam, adaptam-se, renovam-se e multiplicam-se, de forma que não são inovações absolutas (MARCUSCHI, 2005, p. 18). Os rótulos, antes necessariamente físicos e afixados às embalagens, agora estão, também, em um site, um ambiente virtual, mantendo sua identidade funcional, porém com características peculiares, inovando-se do ponto de vista organizacional, como visto na seção 2.3.

Os rótulos virtuais constituem, portanto, um gênero textual que emerge no contexto da tecnologia digital em meio a um conjunto de outros gêneros que, embora não sejam muitos, e estejam ancorados em outros gêneros já existentes, eles - antes mesmo de se consolidarem - "[...] provocam polêmicas quanto à natureza e à proporção de seu impacto na linguagem e na vida social. Isso porque o ambiente virtual é extremamente versátil e hoje compete, em importância, nas atividades comunicativas, ao lado do papel e do som". (MARCUSCHI, 2004, p. 1)

Diante do surgimento de um novo gênero textual, é essencial que seja conhecida a forma pela qual seus objetivos específicos se realizam. Sabe-se que a própria característica dinâmica do gênero textual impede seu domínio completo por parte dos falantes, dos usuários e, no caso desta pesquisa, dos tradutores. É comum, portanto, haver aspectos novos, desconhecidos e inexplorados. Entretanto, é possível afirmar que haja um conjunto de informações que permita ao falante reconhecer um gênero e diferenciá-lo dos demais. Caso contrário, grande parte das tentativas de trabalho com gêneros textuais se tornaria inviável. 
A tarefa, porém, não é tão simples. Marcuschi salienta, por exemplo, que "um gênero pode não ter uma determinada propriedade e ainda continuar sendo aquele gênero". (2002, p. 11) Assim, os gêneros não podem ser definidos de maneira estanque, restritos à presença ou não de um determinado elemento. No escopo desta pesquisa, nem todos os rótulos - físicos ou virtuais - apresentarão os mesmos elementos, mas compartilham de uma função comum: fornecer informações sobre produtos e comercializá-los, evidenciando o predomínio da função sobre a forma na determinação do gênero.

De toda forma, não é possível elencar propriedades necessárias e nem suficientes para definir um texto como pertencente a certo gênero textual. Nesse sentido, Marcuschi destaca que:

[...] pode-se dizer que os gêneros possuem elementos discursivos marcantes que os caracterizam e diferenciam uns dos outros, ao mesmo tempo em que estão carregados de dinamicidade e flexibilidade podendo sofrer modificações consoante as necessidades comunicativas inseridas num determinado contexto sócio histórico. (2005, p. 15)

De certo, esses elementos discursivos marcantes permitem a um falante reconhecer o gênero textual utilizado por outro, na medida em que os usuários da língua moldam sua fala aos gêneros e - em uma relação dialética - também os moldam à sua fala. Para Marcuschi (2005), é o conhecimento e o domínio que o falante - ainda que de forma inconsciente - tem dos gêneros que Ihe possibilita a comunicação verbal.

Os gêneros textuais, portanto, são de construção coletiva. Embora eles possam ser modificados, fundidos e adaptados, esses processos não são decisões individuais, nem são facilmente manipuláveis. Os gêneros textuais refletem características socialmente aceitas no âmbito da comunicação de uma comunidade, o que os leva a operarem, ainda do ponto de vista da comunicação verbal, como "geradores de expectativas de compreensão mútua" (2002, p. 15). 
É possível afirmar, ainda, que os aspectos socioculturais marcadores de um gênero textual corroboram com a construção de diferentes concepções de um mesmo gênero textual em diferentes comunidades. Assim, as informações que são esperadas em um rótulo de cosmético infantil no Brasil podem não ser consideradas usuais em outra comunidade.

A impossibilidade de se estabelecer uma receita que preencha todas as lacunas para a confecção de um rótulo e, nesse caso, para a sua tradução, não impede o pesquisador de buscar esses elementos discursivos marcantes que contribuem com a caracterização de um punhado de textos como rótulos virtuais. Pelo contrário, a mutabilidade e a reinvenção dos gêneros textuais os tornam objetos constantes de pesquisa, e revelam um infinito de possibilidades.

A consolidação de dados em ambiente tão volátil quanto o virtual tornase vital à tradução desse gênero textual, visto que contribui para o encontro do núcleo comum de informações esperadas pelo leitor-consumidor, considerando que as diferentes situações comunicativas apresentam componentes de previsibilidade. Evita-se, assim, a quebra do convencional e, portanto, ruídos na comunicação - não desejáveis na tradução desse gênero textual - cuja tradução requer uma relação de transparência com o consumidor.

Ademais, a tentativa de reunir informações e características que permitam a análise de um gênero textual em especial propicia elementos para a compreensão e para a interpretação de outros gêneros e, por conseguinte, melhor relação com textos diversos. Do ponto de vista da tradução, a mera compreensão de como funciona um texto de gênero tão específico é de grande valia, na medida em que os tradutores podem agir de maneira eficaz diante de textos antes inexplorados ou ainda não percebidos como objeto de tradução. 
5. RÓTULO: FONTE DE INFORMAÇÃO, IDENTIDADE DO PRODUTO E DIFUSÃO DE VALORES CULTURAIS.

O rótulo é um vendedor exclusivo. Em tempos de autosserviço, ele fornece informações, personaliza produtos, identifica suas principais propriedades e confere-lhes destaque diante de tantas cores, formatos e tamanhos expostos ao consumidor nas prateleiras. Nesse contexto, podem ser revelados valores culturais das sociedades em que os produtos são comercializados. Este capítulo é dedicado a explorar os papéis do rótulo como fonte de informação, como identidade do produto e como difusor de valores culturais.

\subsection{RÓTULO COMO FONTE DE INFORMAÇÃO}

O surgimento do autosserviço proporcionou ao consumidor autonomia para escolher mercadorias nas prateleiras e levá-las diretamente ao caixa. A ausência do balcão de atendimento fez surgir a principal responsabilidade do rótulo: fornecer informações necessárias para que o consumidor decida sobre a compra de produtos com segurança. Os rótulos assumiram, então, papel crucial na venda dos produtos, auxiliando o consumidor, que passou a interagir com o produto por meio do rótulo, e não mais do vendedor.

A despeito de quaisquer outras funções desempenhadas pelos rótulos, deve-se destacar que eles são, essencialmente, veículos de informações sobre o conteúdo das embalagens. Por ser o principal meio de comunicação entre o fabricante e o consumidor, o rótulo deve ser claro, preciso e objetivo para facilitar o entendimento das informações pelo consumidor e orientar a escolha adequada de produtos.

À medida que os rótulos foram assumindo esse papel, novas exigências surgiram com relação a eles, grande parte delas no sentido de padronizar as informações, os formatos e a própria linguagem empregada nesses textos. A rotulagem passou a ser parte integrante do produto, tornandose instrumento de informação não apenas para o consumidor, mas também para o sistema de vigilância sanitária. No Brasil, a ANVISA é o órgão responsável pela regulação da rotulagem de cosméticos e estabelece esses 
padrões, sempre visando à garantia da qualidade do produto e, portanto, à saúde do consumidor.

De maneira geral, os cosméticos são produtos de livre comercialização. Diante da possibilidade de serem comprados em diversos estabelecimentos, físicos e virtuais, a qualquer tempo e sem qualquer orientação profissional, eles demandam cuidados especiais em seus rótulos para que sejam adquiridos e usados da maneira correta. Para tanto, é de suma importância que as informações rotuladas nas embalagens estejam de acordo com o estabelecido na legislação, que busca zelar pela saúde e pela satisfação do consumidor.

Cosméticos possuem especificações: o fator de proteção solar, o tipo de cabelo para o qual um shampoo é indicado, a ausência de um ingrediente considerado maléfico à saúde ou a presença de um composto cujos estudos recentes comprovam benefícios ao usuário. Cosméticos infantis, por sua vez, se caracterizam, por exemplo, como "hipoalergênicos", "sem lágrimas", "dermatologicamente testados" e "neutros". São os rótulos que estampam essas e outras características, além de apresentarem informações sobre fabricação, origem, modo e restrições de uso de cosméticos.

São esses parâmetros que, grande parte das vezes, definem a aquisição dos produtos. Para o brasileiro, por exemplo, as datas de fabricação e/ou de validade são essenciais, de forma que a ausência delas pode fazê-lo desistir da compra. Ainda nessa linha, a alergia a determinada substância ou a simples preferência por um ingrediente em detrimento de outro também podem ser decisivas no momento da escolha, de forma que o item de rotulagem "composição" torna-se fundamental para o consumidor.

Ao levar um produto para casa e antes de fazer uso dele, é fundamental que o consumidor se atente para o modo de uso e para as advertências e precauções/instruções quanto ao armazenamento do produto. Dessa maneira, os produtos tendem a ser manuseados de maneira adequada e acidentes de consumo podem ser evitados, embora nem todos os acidentes de consumo sejam ocasionados por mau uso dos produtos. 
Em 13 de janeiro deste ano, a Revista Veja ${ }^{45}$ publicou matéria a respeito de consumidores que desenvolveram bolhas, erupções, rachaduras e sangramentos ao redor da boca após fazerem uso de um popular protetor labial vendido livremente em farmácias e supermercados nos Estados Unidos. O produto era amplamente divulgado por celebridades e blogueiras daquele país, além de ser bastante popular entre os brasileiros, tornando-se uma das marcas mais importantes do mercado.

É importante esclarecer que o consumidor - a menos que já tenha conhecimento prévio - nunca saberá quando um produto poderá causar danos à sua saúde. O fato é que o consumidor está exposto a riscos diariamente. Portanto, nas relações de consumo, ele é considerado parte vulnerável, podendo fazer jus à indenização e à publicidade corretiva, como ocorreu no caso citado no parágrafo anterior. Assim, diante de circunstâncias de risco e de vulnerabilidade, é de suma importância que as orientações do fabricante sejam acessadas e seguidas. Para tanto, elas devem estar à disposição do consumidor em sua língua.

Embora não seja o seu principal foco, esta pesquisa reconhece 0 direito dos consumidores de acesso a quaisquer informações que subsidiem sua escolha no momento da compra na língua do país onde o produto está sendo comercializado. Portanto, acredita-se que os rótulos precisam cumprir o papel de prestar aos consumidores informações sobre os produtos que consomem, não só com o intuito de prevenir acidentes, mas também de escolher entre essências, texturas, efeitos, fragrâncias entre outros elementos que estão relacionados aos próprios gostos e desejos do consumidor.

Rótulos podem ser omissos em diversos aspectos de interesse do consumidor. Nem sempre as informações prestadas são suficientes para evitar problemas relacionados ao consumo ou insatisfação do consumidor por informações não necessariamente vinculadas a acidentes e a desastres, mas a um simples desejo de consumo. Ademais, é comum rótulos que apontam

\footnotetext{
${ }^{45}$ Famosa marca de protetor labial é processada após provocar feridas na boca dos clientes. Disponível em: http://vejasp.abril.com.br/blogs/pop/2016/01/13/eos-protetor-labialrocesso/?utm_source=redesabril_vejasp\&utm_medium=facebook\&utm_campaign=vejasp. Acesso em: $1 \overline{3}$ jan. 2016.
} 
qualidades que não podem ser comprovadas sobre os produtos, o que pode gerar frustração no consumidor ao não conseguir observar em si o resultado prometido pelo produto. Por fim, não há garantia de que todas as informações veiculadas pelos rótulos são verdadeiras, embora o registro na Anvisa seja um mecanismo que busca a certificação prévia dessas informações.

Em 2010, Caneschi et al. realizaram uma pesquisa com o intuito de analisar rótulos de fotoprotetores quanto ao cumprimento das legislações vigentes no Brasil. Das 26 marcas avaliadas (22 destinadas ao público adulto e 4 ao infantil), nenhuma continha nos rótulos informações suficientes e/ou adequadas para orientar o consumidor de modo a obter a proteção solar ideal ao seu tipo de pele e evitar danos como queimaduras, envelhecimento precoce e câncer de pele. Nesse sentido, os autores salientam que:

\begin{abstract}
ao deixar margem para a utilização incorreta deste cosmético [o fotoprotetor] pela população, permite-se que a mesma não atinja 0 benefício esperado, ampliando a possibilidade dos usuários sofrerem danos a curto, médio e longo prazo" (Caneschi et al., 2011, p. 210).
\end{abstract}

Os autores salientam que a utilização incorreta desses produtos por parte da população se deve, em grande parte, às informações incompletas ou omissas nos rótulos. Esses deveriam conter informações mais detalhadas ${ }^{46} \mathrm{e}$ de fácil compreensão para os consumidores, tendo em vista que thes foi transferida a responsabilidade sobre a escolha, a aquisição e a utilização corretas.

Outro aspecto que torna nebulosa a comunicação entre rótulo e consumidor e que, por conseguinte, pode levar a acidentes de consumo é o emprego da Nomenclatura Internacional de Ingredientes Cosméticos (INCI), em detrimento da língua portuguesa, para descrever ingredientes cosméticos de produtos comercializados no Brasil. Caso o consumidor deseje verificar a lista de ingredientes de um cosmético, certamente precisará de ajuda para relacionar nomes de ingredientes no $\mathrm{INCl}$ aos ingredientes que conhece com nome em Português. Destaque-se, entretanto, que a referida nomenclatura já

\footnotetext{
${ }^{46}$ Por exemplo, resistência do produto à água e intervalo de reaplicação do produto.
} 
foi objeto de estudo ${ }^{47}$ desenvolvido por esta pesquisadora, e consiste do capítulo IV da obra "O local e o universal na tradução de produtos cosméticos e comestíveis $^{48 ",}$ portanto não consiste em foco desta pesquisa.

Apesar dos aspectos destacados anteriormente, é necessário esclarecer que não cabe a esta pesquisa, assim como não cabe ao tradutor, a certificação das informações constantes dos rótulos. Os dados observados, analisados e aqui apresentados restringem-se àqueles aos quais esta pesquisadora/tradutora teve acesso na qualidade de consumidora, exposta aos mesmos riscos que os demais indivíduos, e sem poder para verificar tais informações.

Averiguar a eficácia, a qualidade e as características dos produtos não é, e não poderia ser, objeto desta pesquisa. Da mesma forma, essa investigação não é trabalho do tradutor, que deve operar com as informações que Ihe são disponibilizadas, embora seja um pesquisador nato. Deve-se partir do princípio de que a informação disponibilizada é verídica, tendo em vista a própria natureza do rótulo e o "dever ser" da rotulagem.

Do ponto de vista da tradução, é possível afirmar que os rótulos ainda devem muito aos consumidores. Estudos anteriores (ROSCOE-BESSA, 2000; BORGES, 2010 e AQUINO, 2011) evidenciaram o quão falho é o processo de confecção de etiquetas de tradução, que deixa diversas lacunas para 0 consumidor, e muitas vezes não é realizado por tradutor profissional. Assim, no que concerne à tradução, os rótulos estão longe de serem considerados ideais como fontes de informação.

\subsection{RÓtULO COMO IDENTIDADE DO PRODUTO}

Vive-se uma época de proliferação das marcas e das necessidades de consumo, à medida que diariamente surgem novos produtos, fabricantes e conceitos relacionados à beleza, aos cuidados com o corpo e com a higiene pessoal. Se houve um momento, por exemplo, no qual apenas um shampoo

\footnotetext{
${ }^{47}$ BORGES, R. B. de O. Glocali(s/z)ation: o local e o universal na tradução de rótulos de cosméticos. Julho, 2010. Universidade de Brasília.

${ }^{48}$ ROSCOE-BESSA, C; AQUINO, J. S. de; BORGES, R. B. de O. O local e o universal na

tradução de produtos cosméticos e comestíveis. Rio de Janeiro: 7 Letras, 2014.
} 
era suficiente para que os cabelos fossem considerados limpos e bem cuidados, hoje o condicionador, a máscara hidratante, o creme para pentear, o reparador de pontas e o spray finalizador são produtos básicos para muitos consumidores.

Os produtos, expostos nas prateleiras em meio a tantos outros itens, passaram a ser distinguidos pelas marcas de seus fabricantes e pelas mensagens transmitidas por seus rótulos. Esses, em conjunto com as embalagens, personalizam os produtos, identificam as suas principais propriedades e conferem-Ihes destaque.

Essa realidade exigiu que os fabricantes reinventassem os tamanhos, os formatos e as cores das embalagens e dos rótulos, a fim de gerar diferenciais competitivos, visando à divulgação e à venda dos produtos. Nesse cenário, é perceptível que a indústria cosmética é uma das que mais buscam diferenciais em seus rótulos. Por meio de embalagens e rótulos cada vez mais sofisticados, os fabricantes procuram agregar valor e beleza equivalente aos seus produtos:

As empresas desse segmento sabem que uma boa aparência, efeitos perolizados, chamativo com brilho, tátil com textura e apelos sensoriais, por exemplo, quando aplicados aos rótulos agregam muito valor e podem fazer com que os consumidores definam a compra por este ou aquele produto (MENDONÇA, 2013, s/p).

Nesse mesmo sentido, Fabiana Rossi ${ }^{49}$ declara que: "Com certeza o consumidor compra o produto também pela decoração e embalagem hoje. Eles procuram por características inovadoras e com os rótulos adesivos tudo isso é possível."50

Ademais, não fossem as variedades de design das embalagens e dos rótulos, as prateleiras pareceriam exibir diversas unidades do mesmo produto, tendo em vista a padronização das necessidades de consumo e, consequentemente, dos produtos consumidos. Scatolim destaca que "o diferencial é um dos pontos positivos para o produto, em meio àqueles, que,

\footnotetext{
${ }^{49}$ Gerente de marketing da empresa Mack Color, gráfica especializada em rótulos e etiquetas autoadesivas.

${ }^{50} \mathrm{http}: / /$ www.cosmeticanews.com.br/leitura.php?n=rotulos-e-etiquetas-atracao-visual-esensorial\&id=4429
} 
em todas as categorias, não passam de plágio do produto que é ícone, em determinado segmento" (2008, p.3).

Rótulos não apenas identificam produtos, mas têm a capacidade de eternizá-los, pois contêm elementos que provocam sensações no consumidor a partir do uso de texturas, de cores, de formas, de sabores, de cheiros, de sons e de movimentos. De acordo com Scatolim:

o produto passa a ter valor simbólico, estimulando todas as sensações humanas como: a visão, a audição, o tato, o paladar e o olfato. Geralmente é um simples rótulo que tem a função de transferir todas essas informações, visuais ou verbais $(2008$, p. 4).

Nesse contexto, a identidade dos produtos se relaciona diretamente com o nome, com a marca, com o slogan e com os claims ${ }^{51}$, que são apresentados ao consumidor por intermédio dos rótulos. Eles têm papel fundamental no processo que leva o consumidor a fazer escolhas de acordo com suas necessidades e com seus desejos. Em certos casos, a marca ou o nome do produto se tornam sinônimo do tipo de produto. Assim, o consumidor passa a reconhecer e a se referir aos produtos como "Cotonetes", "Bom Bril", "Leite Ninho", "Bubbaloo", "Band-Aid”, "Gillette”, “Leite Moça”, “Isopor”, “Durex”, "Hipoglós", "Maisena" e "Xerox".

\subsection{RÓtULO COMO DIFUSOR DE VALORES CULTURAIS}

A agência americana que regulamenta alimentos e medicamentos (Food and Drug Administration - FDA) apresentou uma proposta de mudança

\footnotetext{
${ }^{51}$ Claims são ferramentas de marketing que transmitem informações, destacam funções, características, benefícios e diferenciais de produtos e serviços. Eles estão presentes, entre outras formas de comunicação, em rótulos dos produtos, anúncios promocionais, campanhas publicitárias e slogans. Em todos os setores de mercado, os claims são utilizados para informar tanto os atributos que destacam um segmento ou uma categoria - como nos rótulos de alimentos apresentados como "diet", "light" e "livre de gorduras trans" - quanto para ressaltar a superioridade ou inovação frente à concorrência. Uma empresa pode alegar que é diferente e melhor do que as demais sob diversos aspectos: nós e nossos produtos e serviços somos mais rápidos, mais seguros, mais baratos, mais convenientes, mais duráveis, mais amigáveis, de melhor qualidade, de maior valor, e assim por diante. As alegações feitas pelas empresas precisam estar em conformidade com a legislação - no que diz respeito às normas específicas para cada segmento e ao que preconiza o Código de Defesa do Consumidor e a Anvisa - e em concordância com os estudos e testes que o fundamentam. Fonte:

http://www.abisa.com.br/noticias/claims-em-produtos\#.VqjNOvkrLIU. Acesso em: 27 jan. 2015.
} 
nos rótulos nutricionais de alimentos embalados. O Órgão alega que os rótulos ainda têm como referência hábitos alimentares e nutricionais dos anos $1970 \mathrm{e}$ 1980, não condizentes mais com a realidade daquele país, tendo em vista o aumento do tamanho das porções de alimentos. As autoridades de saúde argumentam que as mudanças são necessárias para colocar os rótulos em sintonia com a realidade da dieta moderna americana (TEIXEIRA, 2014).

Outro aspecto abrangido pela proposta é a inclusão de uma linha separada para os açúcares adicionados aos alimentos, tendo em vista que muitos especialistas em saúde pública atribuem a esse ingrediente o aumento da obesidade naquele país. Revela-se, portanto, uma mudança de paradigma com relação aos alimentos que causam danos à saúde: as gorduras agora podem e devem ser consumidas; o açúcar, por sua vez, se tornou o grande vilão.

A partir dessa necessidade de elaboração de um novo modelo de rotulagem, verifica-se que o conteúdo dos rótulos varia de acordo com a época em que uma sociedade vive e revela seus costumes, embora momentâneos. Rótulos podem, portanto, ser considerados registros históricos dos hábitos de consumo de uma sociedade em determinada época.

No Brasil, apesar de o conceito de alimentos dietéticos constar da legislação nacional desde 1969, somente em 1988 os produtos diet e light foram enquadrados pelo Ministério da Saúde na categoria de alimentos especiais. Até então, os produtos dietéticos eram considerados medicamentos, tendo em vista serem desenvolvidos para pessoas que apresentavam uma condição médica específica e, por isso, necessitavam de alimentação especial.

Foi a partir de 1980 que o mercado brasileiro de alimentos dietéticos evoluiu, acompanhando uma tendência internacional, embora os adoçantes já fossem liberados no país desde 1965. Propagou-se pelo Brasil, então, uma fartura de produtos dietéticos, antes escondidos em farmácias e lojas especializadas. Hoje, diet, light e "zero" se tornaram sobrenome de diversos alimentos e as vendas desses produtos crescem mais do que as dos segmentos tradicionais. 
Vieira e Cornélio (2007) associam a abundância de produtos dessa categoria à evidente preocupação com a estética e com a manutenção de hábitos alimentares saudáveis no país:

\begin{abstract}
No Brasil, país da proliferação das cirurgias plásticas, clínicas de estética, academias de ginástica e das poções milagrosas para emagrecimento, não poderia ser diferente. Refrigerantes, refrescos em pó, sobremesas, pães, sopas, pratos prontos congelados e até 0 cafezinho com baixas calorias tornaram-se itens obrigatórios na dispensa de muitos brasileiros.
\end{abstract}

A mudança de perspectiva sobre os produtos dietéticos, antes remédios, agora alimentos, bem como a nova tendência de consumi-los, muitas vezes de preferi-los aos tradicionais, define os padrões de embalagem e de rotulagem no que concerne às cores, aos tamanhos, à fonte das palavras light, diet e zero, aos ingredientes destacáveis, aos claims e, certamente, às informações essenciais aos comestíveis.

O apelo ao consumo de produtos menos prejudiciais à saúde retratam valores e ideais da sociedade brasileira na atualidade, mas que variam no tempo e no espaço e estão associados a diversos outros elementos. Diferentes povos, em diferentes momentos, nem sempre compartilham dos mesmos valores, o que torna irrefutável a ideia de que os rótulos, e os próprios produtos em si, estão diretamente relacionados a aspectos sociais e culturais.

Com relação aos cosméticos, os claims também invadiram os rótulos, atentando os consumidores para novos cuidados relacionados aos produtos que consomem e despertando novas maneiras de consultar os rótulos e de adquirir produtos de beleza e higiene pessoal. Assim, hoje se buscam produtos "livres de parabenos", "sem sal", "sem corantes", "hipoalergênicos", e assim por diante. Entretanto, embora a preocupação pareça comum, é possível afirmar que diferentes sociedades conferem tratamentos diversos quanto a essa questão.

Como exemplo, vale destacar o caso dos orgânicos. A eco consciência dos brasileiros ainda é pouco conhecida e divulgada entre os fabricantes de cosméticos, porém, no Brasil, mais da metade dos consumidores considera o 
impacto ambiental dos cosméticos no momento da compra (BOAVENTURA, 2014).

Apesar de a brasileira Natura ser reconhecida como a empresa de beleza mais sustentável do mundo, o Brasil está longe de ser considerado um grande consumidor/fabricante de produtos orgânicos, embora tenha forte potencial em função de sua biodiversidade. O principal entrave está na falta de regulamentação sobre o tema no país, que impede a certificação dos produtos (BOAVENTURA, 2014). Nesse sentido, a Anvisa suspendeu o debate sobre a regulamentação de orgânicos no país por entender que cosméticos não podem ser orgânicos, já que seu processo de fabricação requer, necessariamente, reações químicas (FREITAS, 2014).

Cosméticos orgânicos no Brasil ainda são considerados produtos coadjuvantes, de elevado custo, mais difíceis de serem encontrados, e costumam ser associados aos hábitos de consumo de uma parcela restrita da população. Portanto, as empresas brasileiras ainda estão focadas em produzir e em comercializar cosméticos considerados tradicionais, mas que sejam seguros, ou seja, que não apresentem substâncias que podem fazer mal à saúde, estampando essas vantagens em seus rótulos.

Entretanto, para a ANVISA, as fórmulas tradicionais comercializadas no país estão sob controle, de forma que grande parte dos claims da indústria cosmética não é essencial na rotulagem, visto que a lista de ingredientes é obrigatória e é o item de rotulagem responsável por tais informações. Por outro lado, esses claims podem ser considerados mais valiosos para a população norte-americana, que começa a se engajar em um movimento que tolera menos o uso de componentes químicos e defende a maior presença de ingredientes orgânicos e naturais nas fórmulas dos cosméticos: a Campaign for Safe Cosmetics.

O último aspecto a ser considerado nesta seção é a presença das datas de fabricação e de validade nos rótulos de cosméticos. Produtos comercializados nos Estados Unidos não costumam apresentar essas datas impressas em seus rótulos, pois, além de não ser obrigatória, essa informação não é recomendada pelo FDA. Portanto, os consumidores: 
[...] devem estar cientes de que a data de validade é uma simples estimativa, e que a segurança de um produto pode expirar bem antes de sua validade caso ele não seja armazenado devidamente. Cosméticos expostos a condições inadequadas, por exemplo, elevadas temperaturas, luz solar, ou ainda, abertos e conferidos antes da finalização da venda, podem se deteriorar muito antes do prazo de validade. Por outro lado, se armazenados sob condições ideias, os cosméticos podem ser considerados seguros por um longo período de tempo após atingida a data de validade (FDA, 2002, tradução minha ${ }^{52}$ ).

A partir dessa manifestação do FDA, pode-se afirmar que, para a população dos EUA, a data de validade pode transmitir uma falsa sensação de segurança ao consumidor ou fazer com que produtos ainda seguros sejam descartados sem necessidade. Essa mesma lógica é seguida pelo Canadá, pelo Japão e por alguns países da União Europeia.

Dessa forma, incentivar o consumidor a observar mudanças nas texturas, nas cores e nos cheiros tornou-se mais importante do que determinar dia, mês e ano de vencimento dos cosméticos. Informa-se, ainda, a vida útil dos produtos de beleza, de forma que o consumidor possa avaliar por si próprio a segurança dos produtos de que faz uso.

A vida útil dos cosméticos é apresentada nas embalagens e/ou nos rótulos por meio do desenho de um frasco aberto, com um número e uma letra (M, de month ou $\mathrm{Y}$, de year) (conforme figura 3). Esse símbolo informa que a vida útil do produto passa a contar a partir do momento que ele foi aberto ou que sua vedação foi removida.

Figura 3 - Símbolo representativo da vida útil dos produtos cosméticos

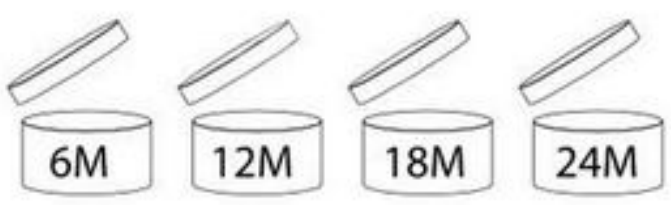

\footnotetext{
52 'Consumers should be aware that expiration dates are simply 'rules of thumb, and that a product's safety may expire long before the expiration date if the product has not been properly stored. Cosmetics that have been improperly stored - for example, exposed to high temperatures or sunlight, or opened and examined by consumers prior to final sale - may deteriorate substantially before the expiration date. On the other hand, products stored under ideal conditions may be acceptable long after the expiration date has been reached".
} 
No caso do primeiro frasco da figura 3 , a vida útil do cosmético é de 6 meses após abertura ou remoção de sua vedação.

Por outro lado, no Brasil, a Resolução n.ำ77/2000 da ANVISA elenca o prazo de validade no rol dos itens da rotulagem obrigatória, ou seja, é considerado informação indispensável à utilização adequada de cosméticos. Os rótulos dos produtos comercializados no país até podem trazer a vida útil como apresentado acima, mas não prescindem da data de validade determinada no formato "dia/mês/ano".

No Brasil, o prazo de validade dita o comportamento social do consumidor, que tem o hábito de verificá-lo antes da compra para se certificar de que o produto prestes a ser adquirido não está vencido ou de que será consumido antes que o prazo expire. O prazo de validade, portanto, tornou-se referência de segurança e de qualidade para o brasileiro e influencia a compra de tal maneira que é bastante comum encontrar promoções de produtos cujo prazo de validade está prestes a expirar.

Diferentes perspectivas com relação à segurança do consumidor podem ser, então, observadas. No Brasil, no que concerne ao prazo de validade, o que determina a compra de um produto é a possibilidade de ele ser usado em sua totalidade até a data pré-determinada em seu rótulo. Em outras culturas, a aquisição do mesmo tipo de produto é determinada pela possibilidade de ele ser consumido em certo número de meses ou anos, porém após ser aberto. 


\section{ANÁLISE E APLICAÇÃO}

Este capítulo se ocupa, em primeiro lugar, da análise de rótulos virtuais de cosméticos infantis fabricados no Brasil e aqui comercializados via lojas virtuais. Com essa análise, pretende-se descrever os principais elementos constituintes e linguísticos dessa nova rotulagem, a fim de subsidiar a produção de traduções de rótulos virtuais de cosméticos infantis, porém fabricados no exterior e comercializados em lojas virtuais brasileiras.

A partir da observação de rótulos virtuais autênticos, mencionada no parágrafo anterior, pretende-se propor traduções que, de fato, subsidiem os consumidores online. Buscar-se-á o delineamento de requisitos mínimos para a rotulagem virtual, pois se sabe que nem sempre os tradutores dispõem de todas as informações que julgariam essenciais para o consumidor, seu público final.

De certo, nas etapas de análise e de aplicação, serão sempre lançados olhares sobre os rótulos físicos, visto que, como apresentado no capítulo anterior, esse novo gênero textual em estudo traz consigo características daquele, a partir do qual se desenvolveu. Ademais, todo o amparo legal que direciona a tradução de rótulos é fundamentado na rotulagem física.

\subsection{INDÚSTRIA E E-COMMERCE BRASILEIROS}

Como mencionado anteriormente, esta primeira seção é dedicada à análise de rótulos virtuais de cosméticos infantis fabricados no Brasil e aqui comercializados via lojas virtuais. Nesse sentido, as seções 6.1.1, 6.1.2, e 6.1.3 dedicam-se a detalhar as escolhas dos sites, das marcas e dos produtos objetos de análise no contexto nacional.

\subsubsection{Sites}

Existem diversos sites que comercializam cosméticos infantis no Brasil, sejam farmácias (e.g. www.ultrafarma.com.br), supermercados (e.g. 
www.paodeacucar.com.br), lojas de departamento (e.g. www.americanas.com) ou lojas especializadas em artigos infantis (e.g. www.bebestore.com.br). A seleção dos rótulos para esta etapa da análise, porém, foi feita a partir dos sites oficiais de fabricantes de cosméticos, embora muitos não vendam seus produtos em suas páginas na internet.

Poder-se-ia argumentar que sites de venda online seriam os meios ideais para a coleta dos rótulos virtuais, visto que um dos papeis primordiais desse gênero textual é a venda, e que ele estaria mais bem representado por sites especializados nessa função. Entretanto, esta pesquisa considera que, no que concernem aos esclarecimentos sobre os cosméticos, os sites oficiais dos fabricantes são a melhor fonte, pois parte-se do princípio de que as informações ali dispostas são seguras e verdadeiras, na medida em que pode haver responsabilização do fabricante por informações equivocadas, confusas ou que induzam o consumidor ao erro. Acredita-se, ainda, que sites dessa natureza apresentam os produtos e as suas características com o objetivo final de vendê-los, mesmo que muitos não efetivem a compra. O processo de venda de um produto pode, portanto, ser iniciado no site do fabricante, que apenas não efetua as operações de pagamento e de entrega, como visto no capítulo 4 .

O corpus de produtos fabricados pela indústria brasileira e comercializados pela internet neste país que foi selecionado para esta análise é composto, portanto, apenas por rótulos virtuais obtidos nos sites oficiais das marcas selecionadas segundo critérios detalhados na próxima seção.

\subsubsection{Marcas}

O levantamento das marcas partiu do conhecimento prévio desta pesquisadora e da observação de rótulos em lojas físicas e virtuais. Buscou-se, no primeiro momento, reunir uma ampla variedade de fabricantes, de marcas, de linhas e de tipos de produtos, de forma que se pudesse apresentar uma proposta de perfil dos rótulos virtuais no mercado eletrônico brasileiro.

As marcas selecionadas a priori foram organizadas em uma planilha que contém, também, os tipos de produtos por elas fabricados (vide apêndice 
A, p. 140). Foram destacadas, então, as seguintes marcas, em ordem alfabética: Baruel ${ }^{53}$, Biotropic Cosmética ${ }^{54}$, Cheirinho de Bebê ${ }^{55}$, Cremer (Hypermarcas) $^{56}$, Dermacyd ${ }^{57}$, Dove (Unilever) ${ }^{58}$, Fofo ${ }^{59}$, Granado ${ }^{60}$, Huggies Turma da Mônica (Kimberly-Clark) ${ }^{61}$, Johnson \& Johnson ${ }^{62}$, Natura ${ }^{63}$, Nazca ${ }^{64}$, Nivea $^{65}$, O Boticário ${ }^{66}$, Palmolive ${ }^{67}$, Phisalia ${ }^{68}$ e Pom Pom (Hypermarcas) ${ }^{69}$.

A fabricante P\&G, embora seja uma das líderes do mercado de produtos para cuidados com bebês, foi excluída da análise, pois a Pampers, sua marca de produtos infantis, é dedicada exclusivamente a fraldas descartáveis, que não são consideradas produtos cosméticos pela Anvisa.

\subsubsection{Produtos}

A indústria de cosméticos infantis vem se desenvolvendo e se diversificando em ritmo acelerado, de forma que o universo de produtos disponíveis é bastante amplo. A oferta varia desde o sabonete básico até itens mais sofisticados como colônias para os cabelos e umidificadores de cachos, passando pelo inusitado polvilho - protetor contra assaduras e irritações, que se diferencia do talco por sua textura fina. Diante de tanta variedade, foi preciso delimitar quais tipos de produtos seriam analisados.

Com esse propósito, a princípio, foram percorridos os sites das marcas escolhidas e listados todos os produtos encontrados, conforme nomenclatura do fabricante (vide apêndice A, p.140). Optou-se por eleger os tipos de

\footnotetext{
${ }^{53}$ www.baruel.com.br

${ }^{54}$ www.biotropic.com.br

${ }^{55}$ www.cheirinhodebebe.com.br

${ }^{56}$ www.cremerinfantil.com.br

${ }^{57}$ www.dermacyd.com.br

${ }^{58}$ www.dove.com.br/pt

${ }^{59}$ www.unilever.com.br

${ }^{60}$ www.granado.com.br

${ }^{61}$ www.huggiesturmadamonica.com.br

${ }^{62}$ www.johnsonsbaby.com.br

${ }^{63}$ www.natura.com.br

${ }^{64}$ www.nazca.com.br

65 www.nivea.com.br

${ }^{66}$ www.boticario.com.br

${ }^{67}$ www.colgate.com.br/app/Palmolive

${ }^{68}$ www.phisalia.com.br/

${ }^{69}$ www.pompom.com.br
} 
produtos que fossem comercializados pela maioria das marcas selecionadas, quais sejam: shampoo, condicionador, água de colônia/colônia, sabonete líquido e sabonete em barra. Acredita-se que, a partir dos produtos de uso comum de grande parte dos brasileiros, é possível propor um perfil dos rótulos virtuais no Brasil.

\subsubsection{Rótulos virtuais}

Esta seção é destinada a apresentar os rótulos virtuais em si, e a descrevê-los para melhor caracterizá-los e subsidiar tanto outras discussões desta pesquisa quanto a tradução de rótulos virtuais. Os elementos aqui incluídos são de observação desta pesquisadora e, quando comuns aos rótulos físicos, são associados a estudos prévios e à legislação vigente no Brasil.

No primeiro momento, caracterizar-se-ão os elementos físicos (6.1.4.1) e, em seguida, serão abordados os elementos linguísticos (6.1.4.2). Ao final de cada uma dessas abordagens, há considerações finais sobre esses elementos, com o objetivo de sintetizar as informações observadas e de tornar o texto mais didático e a leitura mais proveitosa, diante de tantas novas informações. Ademais, essas seções (6.1.4.1.6 e 6.1.4.2.7) possibilitarão comentários extras desta pesquisadora.

\subsubsection{Elementos constituintes}

Como abordado no capítulo 4, rótulos virtuais constituem informações que são disponibilizadas em um ambiente virtual de compra e venda cujas principais finalidades sejam a prestação de informações sobre produtos e a comercialização deles. Do ponto de vista do conteúdo disposto em um site de e-commerce, observaram-se, de modo geral, os seguintes elementos constituintes desses rótulos: nome do produto e grupo/tipo a que pertence, imagem do produto, descrição do produto, resenhas e outros elementos.

Esses elementos serão apresentados a seguir, sendo reservada uma seção para cada. 
6.1.4.1.1 Nome do produto e grupo/tipo a que pertence

O espaço da página da web dedicado à oferta de um produto apresenta, usualmente, o nome do produto e/ou grupo/tipo a que ele pertence, no caso de não estar implícito no nome. Nome, grupo e tipo são designações do produto que objetivam "distingui-lo de outros, ainda que da mesma empresa ou fabricante, da mesma espécie, qualidade ou natureza" (Anvisa, RDC n. ${ }^{\circ} 4$, 2014).

No produto destacado na figura 1 (p. 28), JOHNSON'S ${ }^{\circledR}$ baby HIGIAPELE $^{\circledR}$ é o nome do produto. No caso da oferta apresentada para o protetor solar da figura 2 (p. 30), a marca Coppertone se tornou o destaque, tendo em vista que não é possível observar, por meio da imagem, o nome do produto e nem o grupo/tipo a que pertence. Vale ressaltar que, no texto, também não há menção aos elementos em questão.

\subsection{Imagem do produto}

Muitos sites apostam na disponibilização de imagens dos cosméticos. Assim, propicia-se o primeiro contato visual do consumidor com o produto, embora de forma limitada. Por meio da imagem, é possível se certificar, por exemplo, de que o produto do outro lado da tela é aquele com o qual o consumidor já está familiarizado. Ademais, alguns sites permitem a visualização detalhada das imagens e das informações por meio do recurso zoom.

Grande parte das vezes, essa visualização é parcial, restringindo-se ao painel principal ${ }^{70}$ da embalagem. O painel secundário ${ }^{71}$, por sua vez, não costuma ser disponibilizado ao consumidor para visualização. Algumas das informações constantes desse painel podem ser repassadas ao consumidor por meio do texto do rótulo virtual, que será visto mais adiante.

\footnotetext{
${ }^{70}$ De acordo com o item 2.13 da Resolução n. ${ }^{\circ} 259$ da Anvisa, painel principal "é a parte da rotulagem onde se apresenta, de forma mais relevante, a denominação de venda e marca ou o logotipo, caso existam".

${ }^{71}$ De acordo com o item 2.19 da Portaria n.. 42, de 14 de janeiro de 1998, do Ministério da Saúde, painel secundário "é a parte do rótulo, não habitualmente visível ao comprador, nas condições comuns de exposição à venda, onde deverão estar expressas as informações facultativas ou obrigatórias, a critério da autoridade competente, bem como as etiquetas ou outras informações escritas que constam da embalagem".
} 


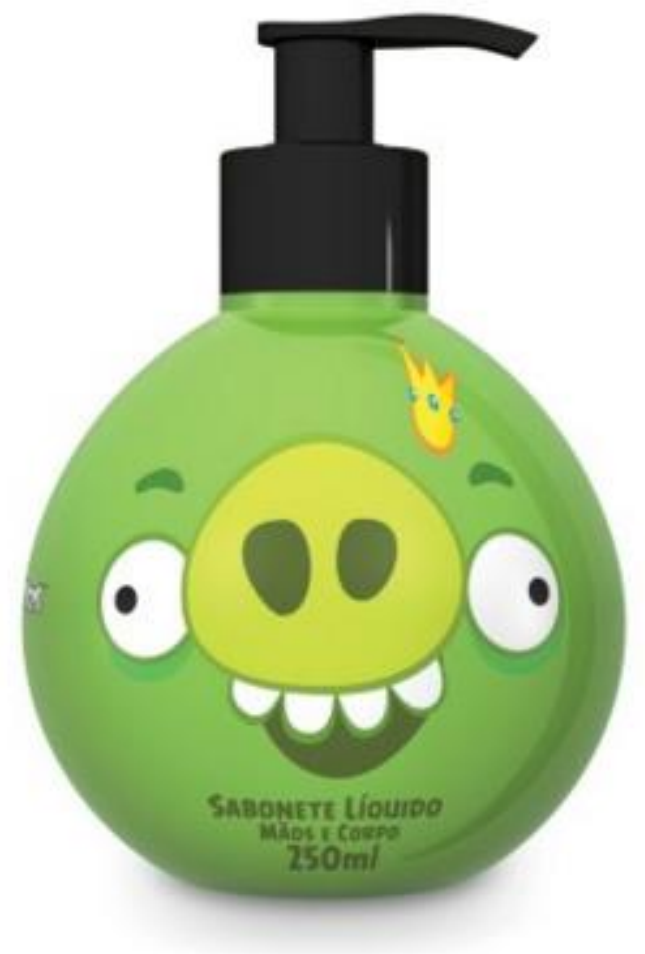

Fonte: www.biotropic.com.br/produtos/infantil/angry-birds

\subsection{Descrição do produto}

Próximo à imagem, abaixo ou ao lado, costuma vir a descrição do produto, um espaço dedicado à apresentação de um texto que contém as suas principais características. É comum que esse texto seja dividido em itens de rotulagem, de maneira bastante similar aos textos dos painéis primário e secundário dos rótulos físicos, quais sejam: conteúdo líquido, modo de uso, composição, advertências e restrições de uso e dados do fabricante. Um item de rotulagem de presença obrigatória nos rótulos físicos, mas que não constituem os rótulos virtuais é o prazo de validade.

Alguns fabricantes e/ou comerciantes online optam por postar textos que se assemelham a uma cópia do rótulo físico no que concerne à estrutura e ao conteúdo do texto em si. Por outro lado, há casos em que os rótulos virtuais 
são apresentados de maneira distinta, com informações reduzidas em relação ao rótulo afixado à embalagem do produto (vide apêndice D, p. 147).

Dessa forma, parece não haver um padrão para a descrição dos produtos em ambiente virtual. Entretanto, entende-se que a sistematização das informações disponibilizadas ao consumidor na internet é essencial nesse momento de euforia com o comércio online, na medida em que, pelo menos no momento da compra, o rótulo virtual substitui o físico e, portanto, entende-se que aquele deva conter informações que subsidiem a escolha do consumidor. Buscar-se-á uma proposta para a referida sistematização no próximo capítulo, que também se ocupará dos aspectos linguísticos deste elemento do rótulo virtual.

Nesse sentido, os rótulos virtuais não precisam conter, rigorosamente, as mesmas informações que os rótulos físicos, entretanto, entende-se que, como ambos possuem funções similares, ao menos os itens de rotulagem básicos, exigidos pela ANVISA devem ser, de igual maneira, requeridos nas lojas virtuais.

\subsection{Resenhas}

As resenhas são avaliações/comentários postados nas lojas virtuais pelos próprios clientes a respeito dos produtos adquiridos online, do serviço prestado e da experiência de compra em si. Esse elemento foi criado pela Amazon.com, maior loja de e-commerce do mundo, de forma inovadora, pois seu fundador acreditava que, se sua loja tivesse mais avaliações feitas pelos próprios compradores do que qualquer outro site, isso thes daria grande vantagem, visto que os clientes ficariam menos propensos a usar outra loja virtual.

Por meio delas, ajudam-se outros consumidores a decidir sobre a compra, de forma que os próprios compradores online fazem papel de vendedores ao apontarem as principais vantagens e os benefícios do produto escolhido. Bezos, fundador da Amazon.com, idealizou as resenhas por acreditar que "não ganhamos dinheiro quando vendemos coisas. Ganhamos dinheiro quando ajudamos os clientes a decidir o que comprar" (STONE, 2014, p. 16). 
Ao mesmo tempo, os feedbacks negativos também colaboram com esse processo na medida em que contribuem com a imagem de transparência da loja virtual e propiciam ao fabricante/vendedor espaço para argumentar com o cliente e gerar uma impressão melhor sobre a marca.

\subsection{Outros elementos}

O comércio eletrônico está em constante desenvolvimento, de forma que diariamente surgem inovações que proporcionam aos consumidores comodidade, transparência e credibilidade em suas compras. Um desses elementos é a personalização do site de forma que, a partir da primeira compra, é disponibilizada ao consumidor uma lista de produtos que possam interessá-lo ou uma lista de produtos que foram adquiridos por outros clientes com interesses comuns.

Ademais, em diversas lojas virtuais há espaço reservado para a apresentação de produtos relacionados àquele que se pesquisa. Assim, caso o consumidor esteja pesquisando um shampoo, é provável que um condicionador e/ou um creme para pentear da mesma linha apareçam no final da página em "produtos relacionados" ou "você também pode gostar de:". Ainda nesse sentido, caso o consumidor esteja pesquisando um produto de uma linha específica, é comum serem-Ihe apresentados todos os demais produtos dessa mesma linha.

No âmbito da Amazon.com, Stone narra que esse recurso de personalização, chamado de Similarities, permitiu que a loja colocasse à disposição de seus clientes livros que poderiam nunca ter sido encontrados senão por ele. Ademais, Bezos acreditava que essa seria uma das vantagens insuperáveis das lojas virtuais sobre as físicas, pois:

Grandes comerciantes nunca tiveram a oportunidade de entender seus consumidores de forma verdadeiramente individualizada. [...]. $\mathrm{O}$ comércio eletrônico vai possibilitar isso. (STONE, 2014, pp. 45; 46)

\subsection{Considerações finais sobre os elementos físicos dos rótulos virtuais}

A partir da breve descrição de alguns elementos da rotulagem virtual destacados a partir da oferta de produtos em ambientes virtuais apresentados nas subseções precedentes, é possível fazer algumas considerações: 
(a) Embora muitos sites de fabricantes e de lojas virtuais sejam ambientes similares e os comerciantes façam uso das mesmas ferramentas para ofertar, vender e entregar seus produtos, sempre há possibilidade de novos recursos serem desenvolvidos e, portanto, de surgirem novos elementos caracterizados dos rótulos virtuais. Ainda nesse sentido, não é possível afirmar que todos os rótulos virtuais apresentarão todos esses elementos de rotulagem física. Dessa forma, os aspectos elencados e destacados aqui são dinâmicos, assim como o próprio comércio eletrônico;

(b) É possível afirmar, a partir da análise apresentada neste capítulo, que o comércio eletrônico representa uma nova revolução na maneira de comprar e, portanto, tem gerado alterações na oferta, na informação e na identificação dos produtos, que agora passam a ser consumidos a partir de rótulos virtuais;

(c) É necessário ter em mente que produtos adquiridos pela internet, quando recebidos, não prescindem do rótulo físico, que cumprirá o papel de assegurar que o consumidor faça uso adequado do produto durante toda sua vida útil. Entretanto, no ato da compra online, prevalecem as informações disponibilizadas pelos rótulos virtuais;

(d) Esses rótulos virtuais têm a mesma função de subsidiar as compras que os rótulos físicos. Por meio do espaço na internet disponibilizado para a oferta do produto, há informações sobre as principais funções do produto, sua imagem é apresentada, e ainda há interação com outros consumidores e, por diversas vezes, com o próprio fabricante.

Nesse sentido, é possível afirmar que há diversas similaridades entre rótulos virtuais e físicos, na medida em que exercem a mesma função, embora cada um com suas peculiaridades. 


\subsubsection{Elementos linguísticos}

Assim como para os elementos físicos, as informações disponíveis nos rótulos virtuais podem ser descritas e, portanto, caracterizadas do ponto de vista da linguagem empregada nesse ambiente de compra e de venda online, 0 que será buscado nessa seção a partir dos seguintes elementos: imperativo, pronomes pessoais e possessivos de segunda pessoa, orações reduzidas de gerúndio, diminutivo, vocabulário e claims.

Entre os elementos listados acima, Roscoe-Bessa (2000), em seu estudo inaugural sobre a tradução de rótulos, verificou - entre as marcas linguísticas mais frequentes desse gênero textual - o emprego de verbos no modo imperativo, de pronomes possesivos, e de pronomes pessoais e verbos na segunda pessoa. A autora ponderou, ainda, que, embora alguns estudos enumerassem os vocativos, as palavras dêiticas, os pronomes de tratamento $\mathrm{e}$ os pronomes interrogativos como recursos característicos da persuasão ${ }^{72}$, eles não eram comuns aos rótulos físicos.

\subsection{Imperativo}

Ao observar o rótulo virtual do Shampoo e Condicionador 2 em 1 Huggies ${ }^{\circledR}$ Extra Suave, pode-se verificar que o modo imperativo é empregado somente nas instruções de uso: "1. Aplique o shampoo nos cabelos molhados massageando-os suavemente até obter espuma. 2. Enxágue em seguida" (grifos meus). Outrossim, no rótulo do Johnson's ${ }^{\circledR}$ baby Shampoo Hora do Sono, há presença do modo imperativo para orientar o consumidor sobre o uso do produto: "Durante o banho do bebê, molhe os cabelos, aplique o shampoo e massageie até obter espuma abundante. Em seguida, enxague bem com água" (sic.) (grifos meus). Esse fabricante faz uso do modo em questão, ainda, nas dicas de segurança sobre o cosmético: "mantenha fora do alcance das crianças" (grifo meu). O item de rotulagem "como usar" do Sabonete em Barra Vegetal Mamãe e Bebê (Natura) faz uso do modo imperativo, seguindo a tendência dos dois produtos analisados anteriormente:

\footnotetext{
${ }^{72}$ SANDMANN, 1997 apud ROSCOE-BESSA, 2000.
} 
Aplique o sabonete em suas mãos umedecidas até formar espuma. Espalhe a espuma sobre o corpinho úmido do bebê, com movimentos delicados. Enxágue até a remoção completa do produto.

Contrariando a tendência acima, o rótulo da Colônia Infantil Hidratação Enriquecida (Dove) apresenta uso do modo imperativo na descrição do produto: "O cheirinho do seu bebê reflete o seu carinho por ele, mas saiba que a pele dele também precisa de um cuidado extra" (grifo meu). A observação dos rótulos de outros produtos Dove permite concluir que marca faz uso do modo imperativo de forma predominante em seus cosméticos infantis. Além desse exemplo, tem-se o rótulo do Desodorante Colônia Petit Sophie Fantasy (O Boticário), que faz uso do modo indicativo nas advertências: "Descontinuar o uso em caso de sensibilização; evitar o contato com os olhos; manter fora do alcance de crianças; manter o produto ao abrigo da luz e calor". (grifos meus)

A partir dos dados apresentados acima, é possível concluir que, nos rótulos analisados, o uso do modo imperativo é reservado, de maneira predominante, às orientações quanto ao modo de uso do produto - sobre o qual o fabricante tem autoridade para aconselhar o consumidor - embora esse recurso apresente alto poder de persuasão e Roscoe-Bessa (2000) tenha observado que a linguagem apelativa dos rótulos seja "caracterizada por uma forte presença de períodos no modo imperativo (p. 69)".

\subsection{Pronomes pessoais e possessivos de segunda pessoa}

O rótulo virtual do Shampoo e Condicionador 2 em 1 Huggies ${ }^{\circledR}$ Extra Suave não apresenta uso de pronomes pessoais e possessivos de segunda pessoa direcionados ao consumidor. $\mathrm{O}$ uso do pronome possessivo adjetivo "sua" em "Sua exclusiva fórmula..." tem como referente o próprio produto. $O$ mesmo padrão é seguido pelo Sabonete Líquido Glicerinado Lavandita (Cheirinho de Bebê), in verbis:

Limpa sem ressecar a pele do bebê por conter GLICERINA VEGETAL, ingrediente essencial para o cuidado com a pele dos recém-nascidos, como também para adultos de todas as idades. 
Testado e aprovado dermatologicamente, sua fórmula HIPOALERGÊNICA desenvolvida com pH fisiológico, mantém o equilíbrio natural da pele evitando seu ressecamento. (DESTAQUES DO FABRICANTE) (grifo meu)

Os pronomes em questão também não são empregados na descrição do Sabonete Pom Pom Leite e Mel:

O Sabonete Pom Pom Leite e Mel é enriquecido com vitaminas e proteínas do leite e do mel, que auxiliam na nutrição e proteção da pele delicada do bebê, além de deixá-la limpa e suavemente perfumada.

No mesmo sentido, a detalhada descrição da linha shampoo, condicionador e creme para desembaraçar da Palmolive Natural Kids, bem como do modo de usar dos produtos da marca também não recorrem ao recurso em análise:

Chega de lágrimas na hora do banho. Com fórmula dermatologicamente testada, desenvolvida especialmente par crianças a partir de 4 anos, a linha de Shampoo, Condicionador e Creme para Desembaraçar Palmolive Naturals Kids para todos os tipos de cabelo é a solução que os pais buscavam para proporcionar aos filhos um banho divertido e deixar seus cabelos lindos, cheirosos, macios e sem nós. A fórmula da linha Palmolive Naturals Kids contém ingredientes que não irritam a pele nem os olhos das crianças, conforme demonstram testes feitos por dermatologistas e oftalmologistas.

Além desses benefícios, a linha Palmolive Naturals Kids para todos os tipos de cabelo conta com a abelhinha Bee em sua embalagem e oferece jogos e passatempos para que a criança possa brincar e se divertir na hora do banho.

Modo de usar:

\section{Shampoo Palmolive Naturals Kids 350ml}

Aplique o shampoo Palmolive Natural Kids no cabelo molhado, massageie suavemente, enxágue e repita a operação, se desejar.

\section{Condicionador Palmolive Naturals Kids 350ml}

Depois passe 0 condicionador Palmolive Naturals Kids principalmente nas pontas, e massageie com suavidade, para deixar o cabelo mais hidratado e macio.

Creme para desembaraçar Palmolive Naturals Kids 150ml 
Para um resultado ainda melhor, aplique o creme para desembaraçar Palmolive Naturals Kids no cabelo úmido ou seco, espalhe bem, penteie e não enxágue. (grifos do fabricante)

Constata-se, portanto, a não predominância de pronomes - pessoais e possesivos - na segunda pessoa do discurso. Essa característica dos rótulos virtuais pode indicar uma tentativa de persuasão do consumidor por meio da ênfase no produto e na sua fórmula, ou seja, nas suas qualidades - embora possa haver puffing $^{73}$ - e não no apelo às necessidades e ao perfil do consumidor, ao contrário do observado por Roscoe-Bessa (2000).

\title{
6.1.4.2.3 Orações reduzidas de gerúndio
}

Observa-se o emprego de orações reduzidas de gerúndio no Shampoo e Condicionador 2 em 1 Huggies ${ }^{\circledR}$ Extra Suave: "Não irrita os olhos nem a pele, garantindo limpeza e desembaraço" e "Aplique o shampoo nos cabelos molhados massageando-os suavemente até obter espuma" (sic.). O mesmo recurso é utilizado, ainda, no rótulo virtual do Johnson's ${ }^{\circledR}$ baby Shampoo Gotas de Brilho " "[...] traz uma fórmula inovadora, com óleo de argan e proteínas da seda, proporcionando brilho e maciez [...], e "[...] o shampoo é suave para o couro cabeludo e limpa os fios [...], trazendo uma sensação de cabelos macios [...]". Outro exemplo é o rótulo do Condicionador Bebê Lavanda (Granado): "Sua fórmula suave desembaraça os fios dos cabelos, facilitando o penteado". O uso de orações reduzidas de gerúndio pode ser verificado, ainda, no rótulo do Desodorante Colônia Petit Sophie Jeans (O Boticário):

\begin{abstract}
Meninas cheias de estilo gostam de estar sempre bonitas e cheirosas e a linha Petit Sophie foi feita especialmente para cuidar do bem estar delas, com magia e encanto, transformando-as em verdadeiras princesas! (grifos do fabricante)
\end{abstract}

\subsection{Diminutivo}

O grau diminutivo é empregado com frequência nos rótulos virtuais dos cosméticos infantis. Sampaio (2000) destaca que o diminutivo tende a

\footnotetext{
${ }^{73}$ Puffing é o "elogio exagerado às qualidades de um produto, ocorre com freqüência, embora seja uma prática condenável” (Roscoe-Bessa, 2000).
} 
realçar uma terminologia mais familiar à criança do que ao adulto. Este, porém, termina incorporando esse recurso à sua fala quando o assunto é a criança.

Esteves et al. (2012) relacionam, entre as hipóteses de uso do diminutivo, a manifestação de ternura e de afetividade. No caso em questão, pode-se inferir que sufixos diminutivos nos rótulos retomam a afetividade entre mães e filhos, na medida em que é comum mulheres fazerem uso de palavras nesse grau ao se dirigirem a seus filhos e quando a eles se referem.

No contexto dos rótulos de produtos infantis, o diminutivo pode ser relacionado, de forma direta, à intencionalidade, por detrás do enunciado, de criar uma sintonia entre o consumidor e o produto (ou a marca). Ao construir uma imagem maternal da marca, o fabricante apresenta maiores chances de convencer a mãe sobre a aquisição de um produto.

Observa-se o uso em demasia desse recurso no rótulo dos produtos da linha Boti Baby (O Boticário): "[...] use em conjunto com Boti Baby Água de Colônia, o Boti Baby Shampoo Suave, para deixar os cabelos do pequenino bem limpinhos e sem o risco de arder os olhinhos dele [...]". A linha "Shampoo, condicionador e shampoo 2 em 1 Tutti-Frutti (Nazca) também apresenta diminutivo em sua descrição: "A versão Tutti Frutti deixa os cabelos do seu filho limpinhos e com um delicioso cheirinho de Tutti Frutti". Da mesma maneira, o rótulo do perfume Bela Colônia Spray para Meninas (Avon) apresenta uso do grau diminutivo na descrição do produto: "O Bela Colônia Spray para Meninas é um perfume com cheirinho que encanta [...]", assim como a descrição da Colônia Avon Baby Calming sem Álcool: "Combinação de citrus moderno e a delicadeza das flores de camomila e copo de leite cremoso. Pode ser utilizado nas roupinhas e lencinhos do bebê".

\subsection{Vocabulário}

A análise detalhada dos rótulos virtuais abrangidos pelo escopo desta pesquisa permitiu observar a repetição de algumas palavras no universo dos cosméticos infantis. Algumas delas foram compiladas na tabela abaixo, que 
também apresenta o nome do produto e a transcrição de trechos dos rótulos virtuais nos quais as palavras em destaque aparecem.

\begin{tabular}{|c|c|c|}
\hline & $\begin{array}{c}\text { JOHNSON'S }^{\circledR} \text { baby } \\
\text { Shampoo Hora do } \\
\text { Sono }\end{array}$ & 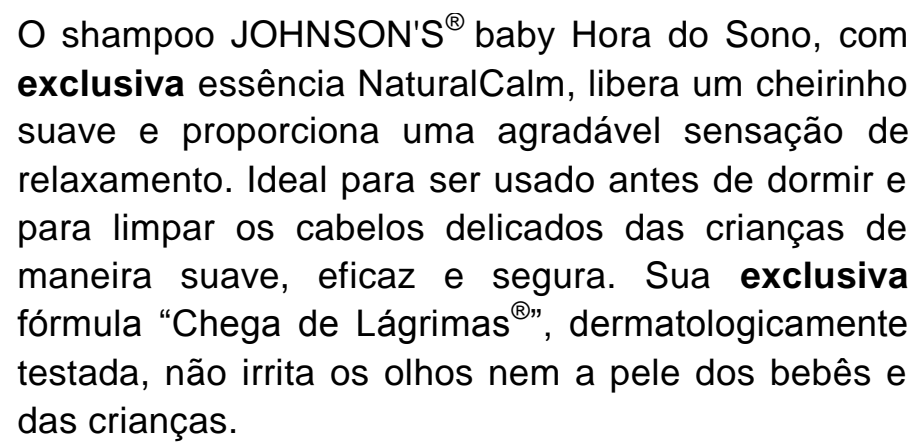 \\
\hline o(a) & $\begin{array}{c}\text { Shampoo Huggies } \\
\text { Cacheados }\end{array}$ & $\begin{array}{l}\text { O Shampoo Huggies Cacheados foi especialmente } \\
\text { desenvolvido para limpar delicadamente os cachinhos } \\
\text { do bebê. Sua exclusiva Fórmula com tecnologia } \\
\text { Huggies, dermatológica e oftalmogicamente testada, } \\
\text { possui ingredientes que ajudam a controlas e definir } \\
\text { os cachinhos, possibilitando hidratação intensa. (sic.) }\end{array}$ \\
\hline
\end{tabular}

Sua fórmula exclusiva, sem corante, com $\mathrm{pH}$ balanceado, não contém álcool. Traz extrato vegetal Sabonete Suave TRÁ de Lavanda e extrato vegetal de Physalis, deliciosos LÁ LÁ BABY Lavanda calmantes. Desenvolvido para limpar suavemente a pele do bebê, sem ressecá-la.

A linha Spulókis traz produtos divertidos e coloridos, Linha Spulókis - O Boticário ideais para fazer do momento de higiene uma das horas divertidas do dia a dia do seu filho. O perfume exclusivo para os meninos tem 0 Theo como representante.

\begin{tabular}{|c|c|c|}
\hline & $\begin{array}{l}\text { Colônia PATATI } \\
\text { PATATÁ Splash de } \\
\text { Alegria }\end{array}$ & $\begin{array}{l}\text { A Colônia PATATI PATATÁ Splash de Alegria possui } \\
\text { fragrância especialmente desenvolvida com } \\
\text { ingredientes suaves que perfumam delicadamente } \\
\text { deixando as meninas prontas para a brincadeira. }\end{array}$ \\
\hline $\begin{array}{l}\text { delicado }(\mathrm{a}) / \\
\text { elicadamente } € \\
\quad \text { suave/ }\end{array}$ & $\begin{array}{l}\text { Sabonete Espuma } \\
\text { Glicerinado da Cabeça } \\
\text { aos Pés Pom Pom }\end{array}$ & $\begin{array}{l}\text { O novo Sabonete Espuma glicerinado da cabeça aos } \\
\text { pés Pom Pom limpa o corpo e os cabelos do bebê de } \\
\text { a forma prática e delicada, deixando-os macios e } \\
\text { perfumados. Testado oftalmo e dermatologicamente. } \\
\text { Mais suave para a pele do bebê. }\end{array}$ \\
\hline $\begin{array}{l}\text { suavemente/ } \\
\text { suavidade }\end{array}$ & $\begin{array}{c}\text { Sabonete Pom Pom } \\
\text { Leite e Mel }\end{array}$ & $\begin{array}{l}\text { O Sabonete Pom Pom Leite e Mel é enriquecido com } \\
\text { vitaminas e proteínas do leite e do mel, que auxiliam } \\
\text { na nutrição e proteção da pele delicada do bebê, } \\
\text { além de deixá-la limpa e suavemente perfumada. }\end{array}$ \\
\hline & $\begin{array}{l}\text { Sabonete Rosa } \\
\text { Cheirinho de Bebê }\end{array}$ & $\begin{array}{l}\text { Sua espuma cremosa e delicada limpa e suaviza } \\
\text { todo o tipo de pele, deixando-a macia e com um } \\
\text { suave perfume. Dermatologicamente testado e } \\
\text { formulado especialmente para minimizar o risco de }\end{array}$ \\
\hline
\end{tabular}


Shampoo e Condicionador 2 em 1 molhados massageando-os suavemente ate obter (a) Sua exclusiva fórmula com tecnologia Huggies ${ }^{\circledR}$ Extra Suave Huggies ${ }^{\circledR}$, dermatológica e oftalmológica testada, possui ingredientes suaves, sem a presença de corantes.

Praticidade na hora do banho - Suavidade para peles e cabelos - Todos os tipos de cabelo e pele. O shampoo Cabelo e Corpo Cheirinho de Bebê possui uma fórmula suave que limpa Shampoo Cabelo e Corpo Cheirinho de Bebê delicadamente, ajudando a preservar a hidratação natural da pele e proporcionando suavidade aos cabelos. Hipoalergênico - especialmente formulado para minimizar 0 risco de reações alérgicas. Testado dermatologicamente. Uso diário.

Shampoo Suave Pom O novo Shampoo Suave Pom Pom foi desenvolvido Pom para limpar delicadamente os cabelos do bebê, sem agredir as raízes e o couro cabeludo.

A Lavanda JOHNSON'S ${ }^{\oplus}$ baby foi especialmente JOHNSON'S ${ }^{\circledR}$ baby desenvolvida para perfumar a pele, proporcionado Lavanda uma gostosa sensação de frescor. Sua fórmula clinicamente testada, tem um Parfum suave $e$ delicado. (sic.) Pode ser usada também para perfumar as roupinhas e o bercinho do bebê.

Condicionador Granado Baby Lavanda

Especialmente desenvolvido para proteger e cuidar dos cabelos delicados do bebê. Sua fórmula suave desembaraça os fios dos cabelos, facilitando o penteado.

O Sabonete Infantil Frozen foi especialmente Sabonete em Barra desenvolvido para a delicada pele da criança. Sua Infantil Frozen fórmula suave limpa e perfuma sem agredir e mantém a hidratação natural da pele.

Avon Baby Calming Colônia sem Álcool

Avon Baby Calming Colônia sem álcool possui suave e deliciosa fragrância que deixa o bebê relaxado e com a sensação de calma e conforto.

suave/

Sabonete em Barra Desenvolvido com Extrato de Lavanda e Manteiga Lavanda do Campo Bebê de Karité, limpa com suavidade, hidrata e deixa a suavidade/ Natureza pele do bebê macia e protegida.

suavemente JOHNSON'S ${ }^{\circledR}$ baby Sabonete Barra Toque Fresquinho
A Tripla Proteção do Bebê é o compromisso de JOHNSON'S $\AA$ baby com uma proteção segura, suave e eficaz, com todo o carinho que o seu bebê merece.

O sabonete JOHNSON'S ${ }^{8}$ baby TOQUE FRESQUINHO ${ }^{\mathrm{TM}}$ contém a tecnologia FRESH 
SENSE ${ }^{\mathrm{TM}}$, composta de agente refrescante $\mathrm{e}$ cheirinho de hortelã e lavanda, ajudando a manter o seu bebê fresquinho por mais tempo, proporcionando bem-estar.

O perfume do Des. Colônia Jeans tem a suavidade Desodorante Colônia Petit necessária para uma perfumação leve e duradoura, Spohie Jeans proporcionando uma deliciosa sensação de conforto, frescor e leveza e ressaltando a jovialidade de toda garota.

Combina a suavidade do JOHNSON'S ${ }^{(\circledast)}$ baby

JOHNSON'S ${ }^{\circledR}$ baby Shampoo Proteção UV

Shampoo TRÁ LÁ LÁ KIDS Musical Sem

Embaraço

Condicionador

Phisalia Jacques Janine Hidratação

Shampoo Transformers

tecnologia Shampoo com ingredientes naturais como a henna, que ajuda a proteger a cor e dar mais brilho aos Proteção UV do bebê, e a melanina, que é reconhecida como um protetor solar natural. Foi especialmente desenvolvido para limpar os cabelos, deixando-os suaves e fáceis de pentear.

Em embalagem familiar de $480 \mathrm{ml}$. Com fórmula suave e $\mathrm{pH}$ adequado é indicado para todos os tipos de cabelos infantis. Limpa e perfuma suavemente dando brilho e maciez aos cabelos. Dermatologicamente testado.

Rico em D Panthenol, Ômega 6 e 9, Queratina e Silicones com $\mathrm{pH}$ balanceado e aliada à tecnologia GIRLS HAIR TECH® Condicionador Phisalia Jacques Janine Hidratação sela as cutículas e promove a hidratação, maciez e revitalização dos fios proporcionando cabelos sem nós, hidratados, com vida e brilho.

Sua fórmula de alta tecnologia, limpa e restaura a força dos cabelos após um dia cheio de ação. Com o $\mathrm{pH}$ adequado para a criança, é indicado para uso diário e pode ser usado em todos os tipos de cabelos. O Sabonete Huggies Toque de Amendôas foi especialmente desenvolvido para limpar Sabonete Huggies delicadamente a pele do bebê. Sua exclusiva Fórmula Amêndoas com tecnologia Huggies, dermatologicamente testada, não irrita a pele, proporcionando uma limpeza segura.

JOHNSON'S ${ }^{\circledR}$ baby Sabonete Líquido Toque Fresquinho $\begin{array}{lll}O & \text { sabonete líquido } & \text { JOHNSON'S } \\ \text { baby TOQUE FRESQUINHO } & \text { TM } \\ \text { contém a }\end{array}$ tecnologia FRESH SENSE ${ }^{\mathrm{TM}}$, composta de agente refrescante e cheirinho de hortelã e lavanda, ajudando a manter o seu bebê fresquinho por mais tempo, proporcionando bem-estar. 
Por meio da leitura dos trechos destacados acima, é possível perceber a repetição de outras palavras além das citadas. Ademais, por meio da tabela é possível verificar mais exemplos de elementos linguísticos explorados nas seções anteriores, embora eles não sejam aqui o foco.

Por fim, é inevitável que os dados também levem o leitor à percepção de características não exploradas neste estudo, tendo em vista a riqueza dos textos e a variedade de tipos de produtos, de marcas e de fabricantes com os quais se trabalha. De certo, um estudo mais detalhado e com metodologia diversa permitiria verificar mais aspectos concernentes ao vocabulário dos rótulos virtuais que muito útil seria aos tradutores.

\subsection{Claims}

Outra característica que merece destaque é o emprego dos claims (cf. p. 46). No Shampoo e Condicionador 2 em 1 Huggies ${ }^{\circledR}$ Extra Suave observam-se os claims "sem corantes" e "livre de lágrimas", a princípio destacados em "Benefícios" e também no espaço destinado à descrição do produto. Porém, neste último, os claims são desenvolvidos em períodos, por exemplo: "possui ingredientes suaves, sem a presença de corantes" (grifos meus) e "Não irrita os olhos nem a pele, garantindo limpeza e desembaraço" (grifos meus). Por outro lado, os claims "exclusiva fórmula com tecnologia Huggies ${ }^{\circledR}$ " e "dermatológica e oftalmológica testada" (sic.) não constam da lista de benefícios do produto, embora apareçam diluídos em um período do texto que descreve o produto: "Sua exclusiva fórmula com tecnologia Huggies ${ }^{\circledR}$, dermatológica e oftalmológica testada, possui ingredientes suaves, sem a presença de corantes".

Os claims são elementos de persuasão: costumam ser curtos (para obter a memorização do leitor), apontam qualidades dos produtos e podem ser facilmente acessados pelo consumidor nos rótulos (vêm destacados no painel principal das embalagens). Dessa forma, eles desempenham importante papel no momento da venda. Os benefícios que os claims destacam costumam ter certificações prévias da Anvisa, configurando-se, portanto, como informações verdadeiras, claras, objetivas e transparentes sobre o produto, como preconiza 
- Código de Defesa do Consumidor. São exemplos desses claims: "hipoalergênico"; "não comedogênico"; "sem lágrimas"; "dermatologicamente testado"; "oftalmologicamente testado"; "com pH balanceado"; "com pH neutro"; "neutro"; "livre de parabenos"; "não contém álcool" e "sem sal”, entre inúmeros outros.

Muitas vezes, os claims podem ser usados em excesso na oferta dos produtos. No caso do Shampoo e Condicionador 2 em 1 Huggies Extra Suave, por exemplo, o texto que descreve o produto é formado por uma sequência de claims em cadeia: "Sua exclusiva fórmula com tecnologia Huggies ${ }^{\circledR}$, dermatológica e oftalmológica testada, possui ingredientes suaves, sem a presença de corantes". Observa-se que claims encadeados são comuns na rotulagem virtual:

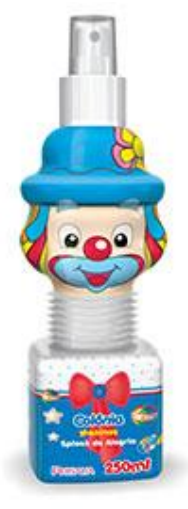

Colônia Patati Patatá Splash de Alegria (Biotropic Cosmética)

A Colônia PATATI PATATÁ Splash de Alegria possui fragrância especialmente desenvolvida com ingredientes suaves que perfumam delicadamente deixando as meninas prontas para a brincadeira. Testada dermatologicamente e de pH balanceado, não contém álcool.

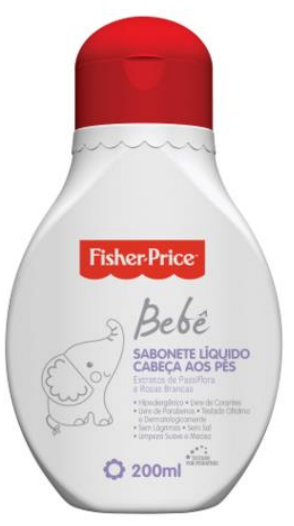

Sabonete Líquido Cabeça aos Pés Fisher Price (Phisalia)

Desenvolvido com a qualidade Biotropic, o sabonete líquido Fisher-Price ${ }^{(\mathrm{R})} \mathrm{Da}$ Cabeça aos Pés higieniza o corpo dos bebês por completo, tornando o banho uma experiência ainda mais agradável. O produto é testado por pediatras, oftalmologistas e dermatologistas, tem fórmula hipoalergênica, sem sal, livre de parabenos e corantes, que não arde os olhos das crianças. Além disso, ainda é livre do conservante Quaternium-15, trazendo ainda mais tranquilidade para os pais. 
Creme contra Assaduras (Granado)

GRANADO

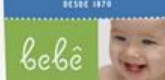

CREME CONT
ASSADUR

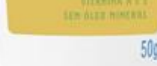

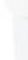

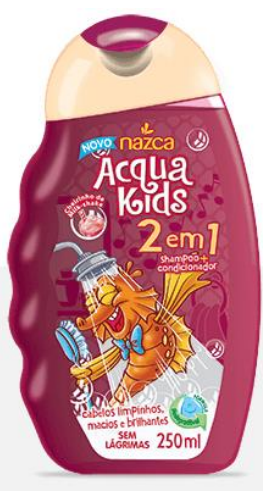

Fórmula à base de cera de soja, que impermeabiliza a pele sem fechar os poros. Produto com alto poder de hidratação, ótima espalhabilidade e remoção. Contém Óxido de Zinco, que forma uma cobertura protetora e facilita o processo de cicatrização. Enriquecido com glicerina vegetal, e Vitaminas A e E. Livre de óleo mineral e parabenos. Hipoalergênico. Dermatologicamente testado.

Shampoo Acqua Kids 2 em 1 Milk Shake

O Shampoo Acqua Kids 2 em 1 é o produto ideal para cuidar dos cabelos da garotada com praticidade, pois reúne duas funções em um só produto. A fórmula é

suave, balanceada e foi testada oftalmo e dermatologicamente, portanto, não irrita os olhos e a pele do couro cabeludo. Cuida da saúde do seu filho e ainda preserva a natureza, porque é biodegradável. A versão Shampoo 2 em 1 deixa os cabelos do seu filho limpinhos, macios, brilhantes e cheios de vida, além do exclusivo cheirinho de Milk-shake.

É preciso atentar-se para o uso de claims que indicam características imprecisas sobre o produto ou até incompreensíveis para o consumidor como: "Sua exclusiva fórmula com tecnologia Huggies $\AA$, dermatológica e oftalmológica testada, possui ingredientes suaves, sem a presença de corantes" (grifo meu). O que é a "tecnologia Huggies ${ }^{\circledR}$ ? Que benefícios ela proporciona ao consumidor? Em que aspectos ela difere das demais fórmulas, tendo em vista que grande parte dos cosméticos infantis apresenta como características testes dermatológicos e oftalmológicos e ausência de corantes? Outro exemplo está no rótulo da Colônia Delicado Cheirinho de Bebê (Baruel Turma da Xuxinha):

Contém exclusivo complexo Pró Milk ${ }^{\circledR}$ (proteína de trigo hidrolisada), que mantém a hidratação natural da pele. Dermatologicamente Testado. Fórmula sem álcool. Fórmula hipoalergênica. (grifo meu)

O que é proteína de trigo hidrolisada? Quais benefícios exclusivos ela traz? É provável que esse claim não remeta o consumidor a ideia alguma de 
exclusividade, e que a grande parte dos consumidores desconheça o complexo Pró Milk ${ }^{\circledR}$ e a proteína de trigo hidrolisada. Entretanto, é possível que o encadeamento de claims possa induzir o consumidor a comprar o produto por associá-lo a boa qualidade.

A Johnson \& Johnson ${ }^{\circledR}$ faz uso de claim semelhante nos rótulos virtuais de seus produtos para banho: "Exclusiva fórmula CHEGA DE LÁGRIMAS ${ }^{\circledR}$ (grifo do autor)". Entretanto, nos próprios textos que descrevem os produtos, o fabricante esclarece o que seja essa fórmula: "Sua exclusiva fórmula "Chega de Lágrimas ${ }^{\circledR}$, , dermatologicamente testada, não irrita os olhos nem a pele dos bebês e das crianças" (grifo meu). Assim, além de explicar de maneira sucinta qual benefício a fórmula traz ao consumidor, esse toma conhecimento de que tal vantagem é comprovada por médicos dermatologistas.

Outrossim, a expressão "CHEGA DE LÁGRIMAS ${ }^{\Theta^{\otimes}}$ é um hiperlink que remete o leitor-consumidor a um novo texto (hipertexto), que apresenta detalhada explicação sobre a fórmula do produto, incluindo os estágios de testes aos quais ele é submetido antes de poder ser usado em uma criança, o que contribui para a credibilidade do consumidor com relação ao produto (vide anexo B, p. 138). O claim "exclusiva essência Natural Calm ${ }^{\mathrm{TM}}$, de forma similar, é detalhado na descrição do produto: "libera um cheirinho suave e proporciona uma agradável sensação de relaxamento".

Como visto nos parágrafos anteriores, os claims são primordiais no processo de venda, na medida em que contribuem para o convencimento do consumidor sobre a compra de um produto a partir de claims que evocam as qualidades que o fabricante deseja destacar em um produto. Pode-se afirmar que, embora a natureza dos claims seja majoritariamente publicitária, eles também são fontes de valiosas informações sobre os produtos.

Entretanto, nem sempre as informações transmitidas pelos claims em um mercado consumidor são autorizadas pela legislação de outro. Assim, no caso da comercialização de produtos importados, é necessário verificar quais aspectos podem e devem, de fato, ser retransmitidos entre diferentes 
comunidades a fim de que sejam evitados problemas com as autoridades sanitárias locais sem, entretanto, privar o consumidor de informações que possam ajudá-lo a decidir sobre a compra.

Os Estados Unidos, por exemplo, se preocupam com o uso de claims que atribuem propriedades medicamentosas aos cosméticos ${ }^{74}$. Alguns casos concernem ao tratamento de caspa e à restauração capilar, enquanto outros prometem o aumento da produção de colágeno e de elastina, o que resulta em uma pele mais elástica e firme, com menos rugas. Há, ainda, casos de cosméticos que melhoram inflamações, regeneram células, previnem contrações dos músculos faciais, além de tratarem acne, rosácea, eczema e psoríase.

Por outro lado, um cosmético comercializado nos Estados Unidos pode "Enhances beauty", "Promotes attractiveness" e "alters appearance". No Brasil, entretanto, esses claims podem ser considerados subjetivos e imprecisos e ir de encontro ao Código de Defesa do Consumidor, que preza pela concisão, pela clareza e pela precisão das informações disponibilizadas na oferta e na apresentação dos produtos, visando a prevenir a publicidade enganosa, que possa culminar em acidentes de consumo e/ou na insatisfação do consumidor.

Dessa forma, é possível constatar que a conjuntura é bastante complexa. Outro exemplo recai sobre a hipoalergenia, característica destacada, por meio de claims, pela maior parte dos rótulos de cosméticos infantis analisados por esta pesquisa. O claim "hipoalergênico" pode ser atribuído aos produtos cujo baixo potencial alergênico seja reconhecido e comprovadamente reduzido em relação a produtos do mesmo tipo e que possuam função similar. No Brasil, fabricantes de produtos cujos rótulos mencionem essa característica são obrigados a apresentar testes clínicos de sensibilização cutânea e fotoalergia, de acordo com metodologia reconhecida, que atestem a baixa incidência de reações adversas de sensibilização e fotoalergia. Ademais, a rotulagem de produtos cosméticos deverá apresentar os seguintes dizeres:

\footnotetext{
${ }^{74}$ U.S Food and Drug Administration. Are Some Cosmetics Promising Too Much? Disponível em: http://www.fda.gov/ForConsumers/ConsumerUpdates/ucm439270.htm. Acesso em: 16 fev. 2016.
} 
"Este produto foi formulado de maneira a minimizar possível surgimento de alergia"75.

No caso dos Estados Unidos, não há normas federais que regulam o uso do termo "hipoalergênico". De acordo com o FDA, o termo significa "o que quer que determinado fabricante deseje"76. Ao contrário do que ocorre no Brasil, não há necessidade de comprovação da hipoalergenia por parte dos fabricantes de cosméticos. Para a Agência, o termo pode ter um papel considerável na promoção dos cosméticos, mas os dermatologistas afirmam que, do ponto de vista técnico, ele significa muito pouco ${ }^{77}$.

\subsection{Considerações finais sobre os elementos linguísticos dos rótulos virtuais}

A partir da observação de elementos linguísticos dos rótulos virtuais destacados na seção anterior, é possível fazer algumas considerações:

(a) Embora os elementos destacados por Roscoe-Bessa (2000) como caracterizadores da linguagem apelativa dos rótulos tenham sido observados na análise anterior, não é possível afirmar que eles sejam predominantes neste estudo. O emprego de verbos no modo imperativo, por exemplo, foi observado com maior frequência nos itens de rotulagem "modo de uso" e "advertências". Com relação aos pronomes de segunda pessoa, observou-se o uso do possessivo adjetivo "sua" e "seu", porém o referente, na maior parte dos casos, é o próprio produto e não o consumidor. Entre as hipóteses que possam justificar o observado, tem-se: o tempo transcorrido desde aquele estudo, na medida em que as ciências avançam diariamente. De certo, novas estratégias de marketing foram desenvolvidas nos últimos anos e outras propriedades dos compostos químicos foram descobertas. É

\footnotetext{
${ }^{75}$ Parecer Técnico no 5 da Câmara Técnica de Cosméticos - CATEC/Anvisa, de 28 de setembro de 2001. Uso do termo "hipoalergênico" em produtos de higiene pessoal, cosméticos e perfumes. Disponível em:

<http://www.anvisa.gov.br/cosmeticos/informa/parecer_hipo.htm>. Acesso em: 16 fev. 2016.

${ }_{77}^{76}$ Tradução minha para: "The term means whatever a particular company wants it to mean".

${ }^{77}$ U.S Food and Drug Administration. "Hypoallergenic" Cosmetics. Disponível em: <http://www.fda.gov/Cosmetics/Labeling/Claims/ucm2005203.htm>. Acesso em: 16 fev. 2016.
} 
possível que o consumidor tenha se tornado mais consciente sobre seus direitos no decorrer desse tempo e, de certo, os órgãos de fiscalização e de regulação elaboraram novos mecanismos para avaliação das fórmulas cosméticas e novas exigências concernentes à rotulagem, concomitante à mudança da legislação. Outra hipótese é a própria divergência de gêneros textuais como esta pesquisa defende. Entretanto, como observado no capítulo 4, há casos em que o rótulo virtual contém as informações do rótulo físico quase que em sua totalidade, mostrando o quão próximos ambos podem ser, embora constituam gêneros textuais distintos. Por outro lado, há casos em que para um mesmo produto são usados textos bastante distintos em rótulos físicos e virtuais. A última hipótese é a de que a análise realizada na pesquisa de Roscoe-Bessa (2000) recorreu a textos traduzidos, enquanto a análise desta pesquisa é fundamentada em textos autênticos. Entretanto, vale salientar que aquela pesquisadora também fez uso de textos autênticos, não apenas de traduções.

(b) Rótulos virtuais, assim como os físicos, são textos que visam à comercialização de produtos e, portanto, são persuasivos. Observou-se que, nos rótulos analisados, a tentativa de convencimento do consumidor sobre a compra é feita principalmente a partir de informações que requerem comprovação técnica, consideradas relevantes para o produto, e que apresentam diferencial competitivo, do que essencialmente com o uso das marcas linguísticas mencionadas no item anterior. Essas informações são transmitidas ao consumidor por meio da descrição do produto e recorrem aos claims como um dos principais recursos.

(c) Conclui-se que os claims constituem hoje um dos principais mecanismos de persuasão da rotulagem virtual, e que eles também são fontes de informações rápidas sobre o produto. Portanto, considera-se primordial o uso desse recurso na tradução de rótulos 
virtuais. Entretanto, é necessário ter cautela com relação às diferenças entre o uso de claims em diferentes países, com o emprego excessivo deles e com os critérios de clareza, precisão e veracidade.

\subsection{APLICAÇÃO}

A seção 6.1 dedicou-se à análise de cosméticos infantis fabricados e comercializados no Brasil. Para tanto, buscou-se caracterizar os rótulos virtuais desses produtos a partir de elementos físicos (nome do produto e grupo/tipo a que pertence, imagem do produto, descrição do produto, resenhas e outros elementos) e linguísticos (imperativo, pronomes pessoais e possessivos de $2^{\text {a }}$ pessoa, orações reduzidas de gerúndio, diminutivo, vocabulário e claims).

Esta seção ocupar-se-á da tradução de rótulos virtuais de produtos importados, ambiente em que a tradução se faz necessária, tendo em vista a importância de que a oferta de produtos a compradores brasileiros esteja em língua portuguesa. Com relação aos tipos de produtos, serão abordados os mesmos tipos de produtos analisados na seção anterior, quais sejam: shampoos, condicionadores, sabonetes e colônias.

\subsubsection{Breve introdução}

$\mathrm{Na}$ loja virtual walmart.com.br, na seção "bebês e crianças", foi encontrada a "Água de Colônia Spray para Bebê 100ml - Musti Eau de Soin Mustela". O item de rotulagem "nome do produto e grupo/tipo a que pertence" permite ao consumidor conhecer: o tipo de produto (água de colônia para bebê), o nome (Musti Eau de Soin), a marca (Mustela) e o conteúdo líquido $(100 \mathrm{ml})$. A loja virtual apresenta a imagem do produto, porém não dispõe do recurso zoom. Na descrição do produto, há os dizeres: "Imagem Meramente llustrativa", o que impede o consumidor de saber quais aspectos da imagem não correspondem ao produto real: cor, tamanho, formato e outros.

O rótulo virtual traz os seguintes dizeres no espaço destinado à descrição do produto: 
Água de colônia spray para bebês de $100 \mathrm{ml}$. Hipoalergênica e sem álcool a Musti associa aroma tenro e delicado de flores e frutos, e extrato de plantas reconhecida por suas virtudes suavizantes. Indicado o uso após o banho para deixar o bebe ainda mais perfumado, contém ingredientes com propriedades calmantes (Sic.).

O primeiro aspecto observado no texto acima é o mau uso da Língua Portuguesa: a ambiguidade da primeira frase, que traz a identificação do produto, permite a indagação: e os bebês que não são de $100 \mathrm{ml}$ ? Além disso, há erros de concordância, de pontuação e de acentuação. Embora a verificação desses erros não seja o foco desta pesquisa, eles não podem passar sem serem mencionados em uma pesquisa que busca meios de aperfeiçoamento da tradução desse gênero textual.

Observa-se no texto uma preocupação com a descrição da fragrância da água de colônia, o que ocupa grande parte do espaço destinado, no site, à apresentação do produto. Assim como observado na análise dos produtos da indústria nacional (seção 4.1), há uso de claims: "Hipoalergênica e sem álcool".

Outro aspecto observado é a ausência de dicas de segurança e de instruções sobre o uso do produto, fundamentais para a comercialização de cosméticos no Brasil. Ademais, não há informações sobre os ingredientes do produto, além daquelas associadas ao aroma que, por sua vez, são imprecisas: "[...] flores e frutos, e extrato de plantas reconhecida por suas virtudes suavizantes".

A partir desta breve análise introdutória, percebe-se a necessidade de propor traduções que se aproximem dos modelos mais usuais ao público brasileiro, e que forneçam dados claros, corretos e em língua portuguesa para assegurarem a compra e a saúde do consumidor. No momento atual, não se acredita que a disponibilização de informações com a rigidez requerida pela ANVISA será realidade nos ambientes virtuais de compras, e tem-se consciência de que o tradutor é apenas mais um agente nessa cadeia que envolve diversos outros interesses. 
Entretanto, acredita-se que o tradutor, desde que disponha de informações elementares para o consumo seguro e consciente, deve optar pela prestação dessas informações ao consumidor de modo objetivo e preciso. Nesse cenário, ele deve se atentar a todas as nuanças que emolduram a tradução desse gênero textual em tela, de forma a produzir um texto que seja capaz de melhorar as relações de consumo na internet, atuando como agente de transformação dos ambientes virtuais.

Diante das observações feitas até aqui, como propor uma tradução que, de fato, subsidie o consumidor online? Como escrever um rótulo virtual que, no momento da compra forneça as informações mínimas para que ela seja segura? De certo, as respostas para esses questionamentos perpassam todo o arcabouço teórico e legal, assim como o conjunto de informações dispostas, associações e análises feitas até aqui.

Como mencionado em oportunidades anteriores ao longo desta pesquisa, não há obrigatoriedade de lojas virtuais disponibilizarem informações sobre os produtos que comercializam com o mesmo rigor que a rotulagem física requer. Porém, há como propor, a partir da observação dos rótulos analisados na seção 6.1 e das informações prestadas de modo oficial pelos fabricantes, traduções que contribuam com a decisão do consumidor de maneira mais eficaz. Vale salientar que o que se propõe como resultado é um texto traduzido, não um site traduzido, portanto, não há preocupações com formatação e com informações relacionadas aos procedimentos de compra. 


\subsubsection{Produto 1.}

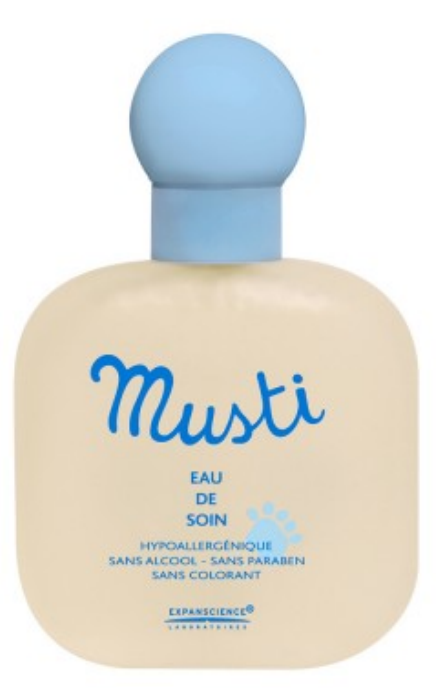

Q Hover over image to zoom

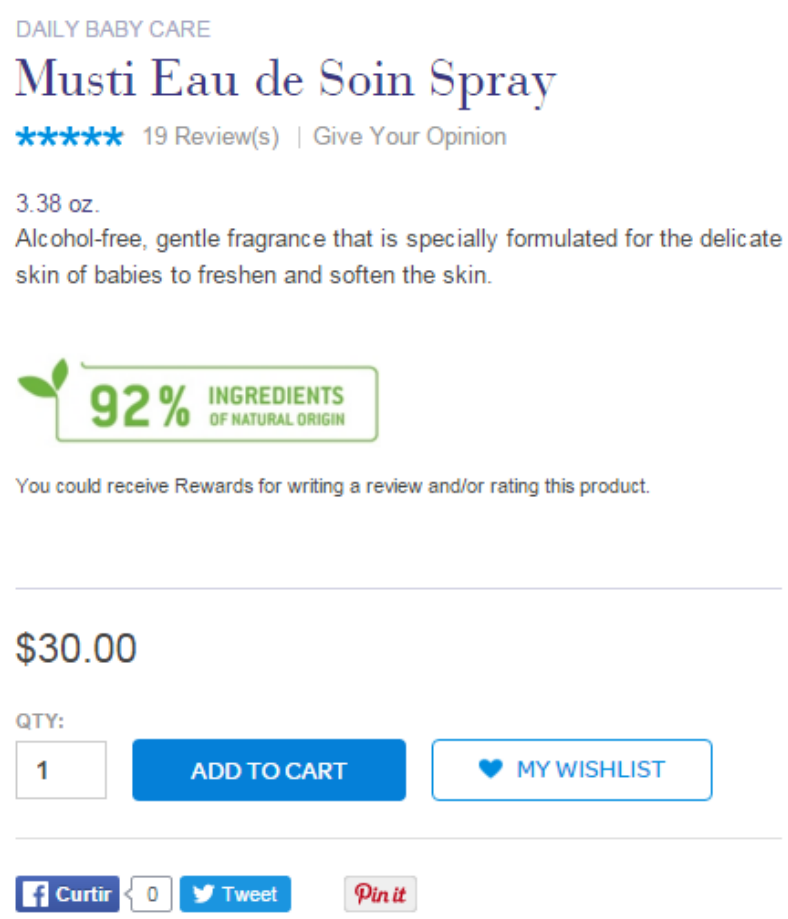

DAILY BABY CARE

Musti Eau de Soin Spray

***** 19 Review(s) | Give Your Opinion

$3.38 \mathrm{oz}$

Alcohol-free, gentle fragrance that is specially formulated for the delicate skin of babies to freshen and soften the skin

\section{f Curtir 0 Tweet Pin it}

PRODUCTINFORMATION:

Alcohol-free, gentle fragrance that is specially formulated for the delic ate skin of babies to freshen and soften the skin.

- May also be used to perfume linens and the nursery.

- Composed of $91 \%$ of ingredients of natural origin and can be used from birth on.

- Paraben, phthalate and phenoxyethanol-free.

- Hypoallergenic and specially formulated to minimize the risk of allergic reactions.

- Tested under dermatological and pediatric control.

DIRECTIONS FOR USE:

Apply Mueti behind the oare, on the nock or on the wriete. Mueti can aleo be ueod to gontly porfume baby'e nureory or linene. Mueti can be ueod from the day your baby is bom.

INGREDIENTS \& NATURALNESS:

AQUA, PEG-40 HYDROGENATED CASTOR OIL, PARFUM, GLYCERIN, SODIUM BENZOATE, BUTYLENE GLYCOL, 1,2-HEXANEDIOL, CAPRYLYL GLYCOL, TARTARIC ACID, CHAMOMILLA RECUTITA FLOWER EXTRACT, MEL EXTRACT

Fonte: http://www.mustelausa.com/shop/musti-eau-de-soin-spray.html 


\subsubsection{Tradução}

Água de Colônia Musti Spray - 100ml

\section{Descrição do produto}

A Água de Colônia Musti Spray foi especialmente desenvolvida para a pele delicada dos bebês. Sua fragrância suave e refrescante não contém álcool.

(a) Pode ser usada para perfumar os lençóis e o berço do bebê.

(b) Mais de $90 \%$ de seus ingredientes são de origem natural.

(c) Sem parabenos.

(d) Hipoalergênico. Este produto foi formulado de maneira a minimizar possível surgimento de alergia.

(e) Testado por dermatologistas e pediatras.

\section{Modo de uso}

Aplique a Água de Colônia Musti Spray atrás dos lóbulos das orelhas, no pescoço e nos pulsos. Pode ser usado a partir do primeiro dia de vida do bebê.

\section{Advertências}

Deve ser aplicado por adulto ou com supervisão de adulto. Não usar na pele irritada ou lesionada. Este produto foi formulado de maneira a minimizar possível surgimento de alergia, em caso de irritação, suspenda o uso e procure um médico.

\section{Composição (INCI)}

AQUA, PEG-40 HYDROGENATED CASTOR OIL, PARFUM, GLYCERIN, SODIUM BENZOATE, BUTYLENE GLYCOL, 1,2-HEXANEDIOL, CAPRYLYL GLYCOL, TARTARIC ACID, CHAMOMILLA RECUTITA FLOWER EXTRACT, MEL EXTRACT. 


\subsubsection{Observações sobre a tradução}

O primeiro aspecto que merece destaque é o nome do produto. É bastante comum cosméticos importados serem comercializados no Brasil mantendo o nome do tipo de produto em língua estrangeira. Assim, uma opção para o elemento de rotulagem nome do produto e grupo/tipo a que pertence seria "Água de Colônia Musti Eau de Soin Spray" ou "Musti Água de Colônia Eau de Soin Spray". Entretanto, optou-se por "Água de Colônia Musti Spray".

É necessário converter o conteúdo líquido da água de colônia de ounces (oz.) para mililitros (ml.). Assim, $3.380 z$ correspondem a $100 \mathrm{ml}$, informação incluída junto ao elemento "nome do produto e grupo/tipo a que pertence", como de costume nos rótulos virtuais brasileiros.

Com relação à porcentagem de ingredientes naturais, há um desencontro de informações no rótulo virtual: há a informação "92\% ingredientes of natural origin" e na seção "product information" há: "Composed of $91 \%$ of ingredients of natural origin and can be used from birth on". Optou-se, então, por "mais de $90 \%$ de seus ingredientes são de origem natural". Com relação à possibilidade de uso do produto a partir do nascimento, considerouse mais pertinente fornecer essa informação no modo de uso do produto.

Com relação ao claim "Paraben, phthalate and phenoxyethanol-free", optou-se simplesmente por "sem parabenos" pelas razões expostas a seguir. A primeira observação importante a ser feita é que não há, no Brasil, qualquer recomendação da Anvisa no sentido de restringir o uso das substâncias em questão por não haver malefícios comprovados. Dessa maneira, a tradução do rótulo virtual poderia simplesmente excluir essas informações, visto que não são essenciais à saúde do consumidor e a ausência delas garante o consumo seguro do produto.

Entretanto, há médicos e estudos que contraindicam o uso dessas substâncias. Pesquisas associam os parabenos a casos de câncer de mama, e há estudos que relacionam os ftalatos à disfunção hormonal e à diminuição da 
fertilidade masculina. Na Europa, inclusive, o uso de ftalatos em cosméticos é proibido.

No Brasil, o uso de produtos que contenham essas substâncias em suas fórmulas ainda é uma decisão pessoal do consumidor, que pode preferir comprar produtos sem nenhuma delas, ou para quem a presença delas é indiferente. Já é comum entre brasileiros a procura por cosméticos sem parabenos, e essa informação consta da oferta de alguns produtos, como pode ser verificado nos exemplos da seção 6.1.4.2.6 sobre claims. De maneira contrária, não foi encontrada, nos rótulos virtuais observados para esta pesquisa, qualquer menção a ftalatos e a fenoxietanol. Deparou-se uma única vez com "sem adição de ftalatos" no rótulo físico do Johnson's baby Shampoo Hora do Sono.

Assim, optou-se por incluir apenas a informação que já é mais familiar aos brasileiros: "sem parabenos". De toda forma, acredita-se que, desde que 0 rótulo apresente a composição, os consumidores podem identificar a presença ou a ausência de ftalatos e de fenoxietanol nos cosméticos. Caso a opção de tradução fosse pela omissão dos ingredientes, provavelmente recomendar-seia a inclusão do claim "sem parabenos, ftalatos e fenoxietanol". De fato, quando se trata da segurança do consumidor, o excesso de informações é melhor do que a falta delas, entretanto, acredita-se que a opção por não incluir "ftalatos" e "fenoxietanol" nos claims não consiste em falta de informação, como argumentado anteriormente. De toda forma, considera-se a tradução "sem parabenos, ftalatos e fenoxietanol" possível. Ela apenas não é a opção desta pesquisadora enquanto tradutora. É possível, ainda, a tradução "livre de parabenos" ao invés de "sem parabenos".

Poderia ser incluído o claim "sem corantes". Embora esta informação não esteja presente na descrição do produto, é possível percebê-la na imagem do produto. Com relação à hipoalergenia, o tradutor deve acrescentar os dizeres "Este produto foi formulado de maneira a minimizar possível surgimento de alergia", sempre que disser que um produto contém essa característica, como visto anteriormente. 
O item "advertências" merece a atenção dos tradutores, tendo em vista que é obrigatório, ao menos para os rótulos físicos, sem os quais os produtos não podem ser comercializados no país. O rótulo virtual de referência não contém nenhum alerta de segurança com relação ao uso e ao manuseio do produto. Entretanto, de acordo com o Anexo II, da Resolução n. ${ }^{\circ}$ 15/2015 da ANVISA, os perfumes e as águas de colônia infantis devem apresentar as seguintes advertências de rotulagem:
a) Deve ser aplicado por adulto ou com supervisão de adulto.
b) Para os produtos contendo álcool: Inflamável
c) Não usar na pele irritada ou lesionada.
d) Em caso de irritação, suspenda o uso e procurar um médico.

Dessa forma, foram acrescentadas as advertências pertinentes na proposta de tradução.

A composição do produto é apresentada na nomenclatura $\mathrm{INCl}$, extraída do rótulo virtual de referência, é item obrigatório na rotulagem física e, no caso da virtual, contribui para a visualização de ingredientes cosméticos que possam gerar tanto benefícios quanto malefícios ao consumidor, inclusive em casos particulares de alergias e reações adversas. $O$ fato de os ingredientes não serem apresentados em língua portuguesa foi objeto de estudo e de publicação em $2014^{78}$.

Por fim, ressalte-se que diferentes partes do texto em questão poderiam ser suprimidas na tradução. Poder-se-ia, por exemplo, apostar apenas no uso dos claims de modo topicalizado ou encadeados em poucos períodos, como visto na seção 4.1. Assim, outra opção de tradução seria:

"A Água de Colônia Musti Spray $100 \mathrm{ml}$, testada por dermatologistas e pediatras, possui fórmula suave, hipoalergênica, sem parabenos, sem álcool e

\footnotetext{
${ }^{78}$ ROSCOE-BESSA, AQUINO \& BORGES, 2014.
} 
sem corantes. Este produto foi formulado de maneira a minimizar possível surgimento de alergia."

Esta opção é interessante por ser mais abreviada e, portanto, assimilarse aos contrarrótulos de produtos cosméticos físicos. É uma opção que foi explorada apenas na análise deste primeiro produto, mas que poderia ser empregada para todos os exemplos apresentados adiante.

Por fim, vale ressaltar que o objetivo não é traduzir a página da internet onde o produto está apresentado, mas os elementos que constituem, nos termos desta pesquisa, o rótulo virtual, produzindo um texto que exerça as funções de informar e de comercializar produtos cosméticos infantis na comunidade para a qual se dirige. 


\subsubsection{Produto 2}

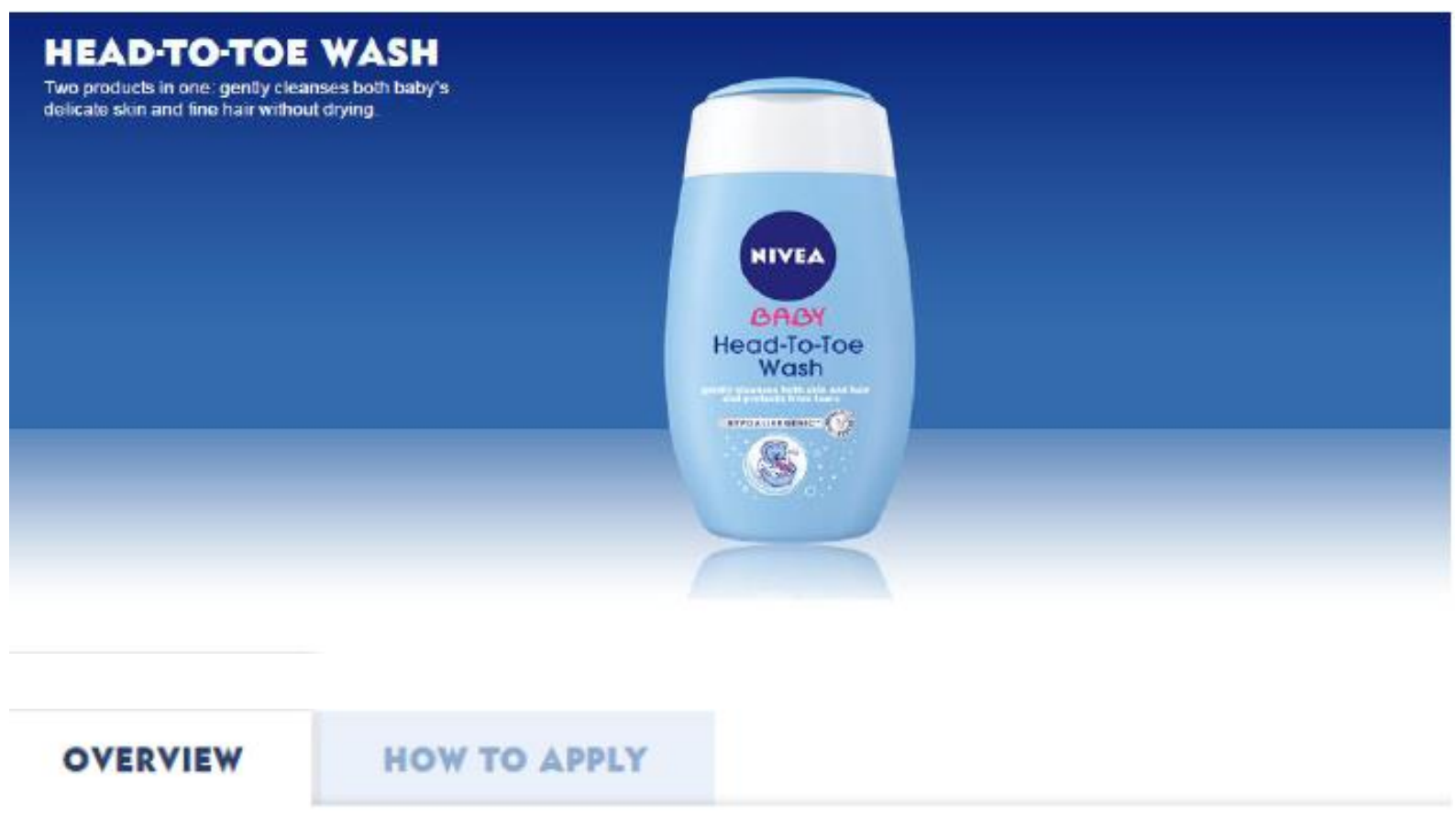

The formula with chamomile strengthens the skin and gently cleanses to prevent skin and hair from drying. Leaves skin and hair feeling clean, soft and smooth.

Gently cleanses both skin and hair and protects from tears.

Hypoallergenic and especially skin-friendly ingredients reduce risk of allergies.

Skin compatibility clinically and dermatologically approved.

$0 \%$ parabens, alcohol and colorants. Skin-friendly $\mathrm{pH}$ value.

\section{HOW IT WORKS}

The formula with chamomile strengthens the skin and gently cleanses to prevent skin and hair from drying. Leaves skin and hair feeling clean, soft and smooth.

\section{OVERVIEW}

\section{HOW TO APPLY}

Add 2-3 squirts of NIVEA Baby Gentle Shampoo \& Bath to bath water and wash hair and skin with a soft and wet washcloth. Rinse with warm plain water. 


\subsubsection{Tradução}

\section{Nivea Baby Sabonete Líquido Suave da Cabeça aos Pés}

\section{Visão geral}

O Nivea Baby Sabonete Líquido Suave da Cabeça aos Pés limpa suavemente a pele delicada e os cabelos finos do bebê, impedindo o ressecamento. Sua fórmula com camomila fortalece a pele do bebê e proporciona leveza e maciez à pele e aos cabelos.

(a) Limpa os cabelos e a pele suavemente. Não arde os olhos.

(a) Hipoalergênico. Este produto foi formulado de maneira a minimizar possível surgimento de alergia.

(b) Aprovado por dermatologistas.

(c) Livre de parabenos, álcool e corantes.

(d) $\mathrm{pH}$ ideal para a pele do bebê.

\section{Modo de uso:}

Aplique uma pequena quantidade do Nivea Baby Sabonete Líquido Suave da Cabeça aos Pés diretamente na água do banho. Lave o corpo do bebê com uma esponja macia e umedecida, massageando os cabelos com as pontas dos dedos. Enxágue com água morna corrente.

\section{Advertências:}

Este produto deve ser aplicado por adulto ou sob sua supervisão. Não usar se o couro cabeludo estiver ferido ou irritado. Em caso de irritação, suspender o uso e procurar um médico. Caso o produto entre em contato com os olhos, lavar com água corrente em abundância e procurar um médico. 


\subsubsection{Observações sobre a tradução}

Outra possibilidade de nome para o produto, como visto no produto 1 , seria Nivea Baby Sabonete Líquido - Head-to-toe wash, optando-se pela manutenção do nome do produto em língua estrangeira, antecedido do tipo de produto "Sabonete Líquido" de maneira evidente para os não falantes de língua inglesa.

Observou-se nos rótulos em língua inglesa, assim como em língua portuguesa, a repetição de palavras. Entre elas, podem-se citar: clean, delicate, gentle, gently, soft e smooth. Ademais, essa repetição não se restringe ao vocabulário, mas também às ideias, de forma que muitos rótulos empregam as mesmas palavras para se referir tanto à ação do produto, quanto à pele do bebê, por exemplo. Observe o seguinte trecho do rótulo virtual do produto em análise: "The formula [...] gently cleanses [...]" e "Leaves skin and hair feeling clean, soft and smooth".

Deve-se atentar para que a tradução não se torne muito repetitiva. Embora a repetição seja uma característica desse gênero texto, do ponto de vista da tradução procura-se mais objetividade, tendo em vista que, em grande parte dos casos, o espaço destinado à tradução é limitado, e que a proposta é informar o consumidor sobre as qualidades e propriedades dos produtos de forma concisa e clara.

$\mathrm{Na}$ tradução proposta, é comum observar trechos em que há fusão de informações similares em um único período, a fim de consolidá-las. Nos trechos destacados a seguir, é possível observar que as descrições do produto e da fórmula são similares: "Two products in one: gently cleanses both baby's delicate skin and fine hair without drying" (produto) e "The formula with chamomile strengthens the skin and gently cleanses to prevent skin and hair from drying" (formula). A opção de tradução foi:

O Nivea Baby Sabonete Líquido Suave da Cabeça aos Pés limpa suavemente a pele delicada e os cabelos finos do bebê, impedindo o ressecamento. Sua fórmula com camomila fortalece a pele do bebê e proporciona leveza e maciez à pele e aos cabelos. 
Em português, é comum os textos das descrições começarem com o nome do produto e, em seguida, serem incluídas informações sobre a fórmula, como visto na seção 4.1. Procedeu-se dessa forma no trecho traduzido acima. As informações sobre a fórmula foram consolidadas no segundo período da descrição.

O elemento "how it works" foi excluído da tradução, pois é uma repetição de um trecho já empregado na descrição do produto, qual seja: "The formula with chamomile strengthens the skin and gently cleanses to prevent skin and hair from drying. Leaves skin and hair feeling clean, soft and smooth".

Com relação ao modo de uso, a tradução escolhida para "2-3 squirts" foi "uma pequena quantidade", por considerá-la mais usual ao brasileiro. Poder-se-ia optar, ainda, por "um pouco". Observou-se a comum recomendação de uso de toalhinhas (washcloth) para o banho dos bebês. Entretanto, considerou-se mais comum recomendar o uso de uma esponja, no caso macia e umedecida. Ainda nesse sentido, a opção por "massageando com as pontas dos dedos" se deve ao fato de que a esponja, no caso, servirá apenas para lavar o corpo e não os cabelos, ao passo que a toalhinha poderia ser usada para lavar ambas as partes do corpo do bebê.

No rótulo virtual de referência, não há dados sobre o conteúdo líquido e nem sobre a composição do produto. Assim, os claims tornam-se fundamentais por serem a única informação sobre a composição: "Livre de parabenos, álcool e corantes".

Assim como procedido no Produto 1 (Seção 4.2.1), acrescentaram-se as advertências sobre o uso do produto conforme indicadas ela ANVISA e, sem as quais, produtos não podem ser comercializados no Brasil em lojas físicas:

Este produto deve ser aplicado por adulto ou sob sua supervisão. Não usar se o couro cabeludo estiver ferido ou irritado. Em caso de irritação, suspender o uso e procurar um médico. Caso o produto entre em contato com os olhos, lavar com água corrente em abundância e procurar um médico. 


\subsubsection{Produto 3}

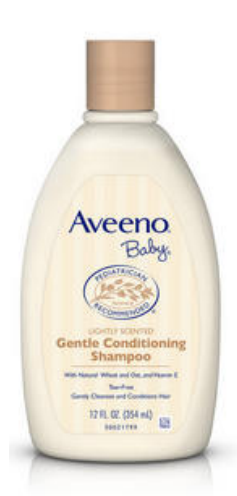

\section{AVEENO ${ }^{\circledR}$ BABY GENTLE CONDITIONING SHAMPOO}

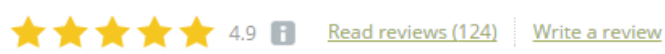

Cleanse, condition, and nourish your

baby's hair.

AVEENO ${ }^{\circledR}$ Baby Gentle Conditioning Shampoo blends natural wheat, oat and vitamin E to gently cleanse and condition hair. Specially formulated for your baby's delicate hair, this unique conditioning formula leaves hair soft, smooth, and easy to manage with a fresh, light fragrance. The allergy-tested formula is gentle enough for babies' sensitive skin. It's tear free, soap free and paraben free.

$12 \mathrm{fl} \mathrm{oz} \quad$ MSRP $\$ 8.99 \quad$ Find in Stores

FIND ONLINE:

amazon.com $\quad$ OTARGET $\quad$ drugstore $\cdot$

INGREDIENTS

ACTIVE NATURALS ${ }^{\otimes}$ OAT EXTRACT

Carefully extracted from the oat kernel, ACTIVE NATURALS ${ }^{\oplus}$ Oat Extract provides a soothing effect while gently nourishing delicate skin.

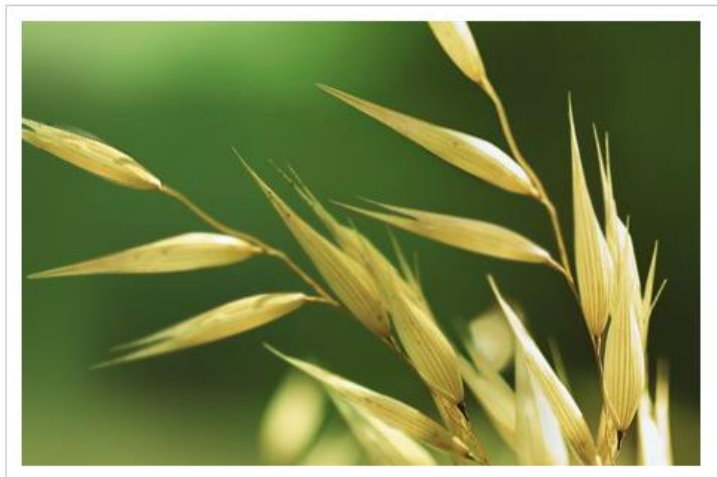

\section{REVIEWS}

We love Aveeno baby shampoo

February 1, 2014

This is the best shampoo ever. I use it daily to wash my baby's hair. It keeps my baby's hair clean and silky.

I recommend this product.

\section{Great product}

February 1, 2014

Absolutely a great product. Love it for my little one. Works wonderfully. A must have!!!!

\section{I recommend this product.}




\subsubsection{Tradução}

Aveeno ${ }^{\circledR}$ Baby Shampoo Suave

Deixa os cabelos do bebê limpos, macios e hidratados.

O Aveeno ${ }^{\circledR}$ Baby Shampoo Suave foi especialmente desenvolvido para a pele sensível dos bebês. Sua fórmula exclusiva com trigo, aveia e vitamina $E$ limpa os cabelos delicados dos bebês, deixando-os macios e fáceis de pentear, com uma fragrância fresquinha e suave. Livre de lágrimas, de sabão e de parabenos. Hipoalergênico. Este produto foi formulado de maneira a minimizar possível surgimento de alergia.

Ingredientes:

Fórmula com extrato de aveia ACTIVE NATURALS ${ }^{\circledR}$

Extraído cuidadosamente a partir do grão, o extrato de aveia ACTIVE NATURALS ${ }^{\circledR}$ proporciona uma sensação de maciez enquanto hidrata a pele delicada do bebê.

Advertências:

Este produto deve ser aplicado por adulto ou sob sua supervisão. Não usar se o couro cabeludo estiver ferido ou irritado. Em caso de irritação, suspender o uso e procurar um médico. Caso o produto entre em contato com os olhos, lavar com água corrente em abundância e procurar um médico.

Conteúdo líquido: 354ml

Resenhas

Amamos o Aveeno ${ }^{\circledR}$ Baby Shampoo Suave

$1^{\circ}$ de fevereiro de 2014 
Melhor shampoo do mundo. Lavo o cabelo do meu filho todo dia com ele. Fica limpo e sedoso.

Ótimo produto

$1^{\circ}$ de fevereiro de 2014

Com certeza um ótimo produto. Amo lavar o cabelo do meu filho com ele. Funciona perfeitamente bem. Tem que ter!!!!! 


\subsubsection{Observações sobre a tradução}

Assim como destacado no produto anterior, o primeiro período do texto que contém a descrição do produto foi reservado, na tradução, à característica mais genérica do produto, qual seja: "foi especialmente desenvolvido para a pele sensível dos bebês" ("Specially formulated for your baby's delicate skin"). Ressalte-se que, como observado na seção 6.1, optou-se por não utilizar o pronome possessivo de segunda pessoa (seu bebê).

O segundo período do texto traduzido é dedicado à fórmula do produto. Optou-se por reunir, em um único período, todas as características da fórmula: seus ingredientes especiais "trigo, aveia e vitamina E"; sua ação, que é deixar os cabelos macios e fáceis de pentear; e sua fragrância, fresquinha e suave. No caso de "fresquinha", fez-se uso do diminutivo, recurso comum nos rótulos de produtos infantis como visto anteriormente na seção 4.1, mas que deve ser usado com cautela. Acredita-se que seja a melhor opção para fresh.

"Recomendado por pediatras" é um claim que não está no texto de descrição do produto, mas poderia ser acrescentado, já que é possível visualizá-lo por meio da imagem do shampoo. Caso essa fosse a opção, a informação poderia ser acrescentada junto aos demais claims: "Livre de parabenos, de sabão e de corantes, o produto é recomendado por pediatras". Ainda sobre os claims, "the allergy-tested formula" foi traduzido por "hipoalergênico", seguido pelo dizer: "este produto foi formulado de maneira a minimizar possível surgimento de alergia".

Não há informações sobre o modo de uso do produto. Com relação aos ingredientes, o rótulo virtual não apresenta a composição completa com os ingredientes na nomenclatura $\mathrm{INCl}$, apenas destaca o ingrediente extrato de aveia ACTIVE NATURALS ${ }^{\circledR}$, informação que poderia ser suprimida da tradução, que não geraria prejuízos à segurança do consumidor.

O último elemento de rotulagem são as duas resenhas. Como visto na seção 6.1.4.1.4, elas são elementos de rotulagem virtual e ajudam outros 
consumidores a decidir sobre a compra a partir da opinião de compradores que adquiriram o produto previamente. Nesse cenário, os consumidores digitais fazem as vezes de vendedor, ao destacarem as principais vantagens do produto em avaliação. É provável que não haja resenhas elaboradas por consumidores estrangeiros e publicadas em sites de comércio eletrônico no Brasil em português. É mais comum que se espere a publicação de resenhas diretamente em português, em sites de compras nacionais.

Entretanto, resenhas que prestam informações sobre os produtos podem e devem ser traduzidas, a fim de que experiências sobre o produto entre compradores de diferentes locais do mundo, em diferentes momentos, sejam trocadas, e a experiência da compra seja enriquecida.

No caso do rótulo virtual do Aveeno ${ }^{\circledR}$ Baby Shampoo Suave, foram traduzidas duas resenhas. Deve-se observar o hibridismo entre a escrita e a oralidade nas resenhas, na medida em que o consumidor, ao postá-las, faz uso de elementos da fala, porém de maneira escrita. Assim, as resenhas - inseridas no contexto dos gêneros textuais digitais - disponibilizam situações de comunicação instantânea, embora não sejam necessariamente apagadas e nem respondidas por outros internautas.

Nesse sentido, faz-se crucial buscar o uso de uma linguagem menos formal e mais próxima à fala para a tradução das resenhas. Entre os exemplos, tem-se: "I use it daily to wash my baby's hair", traduzido por: "Lavo o cabelo do meu filho todo dia com ele" e "A must have!!!!!", traduzido por: "Tem que ter!!!!". 


\subsubsection{Produto 4}

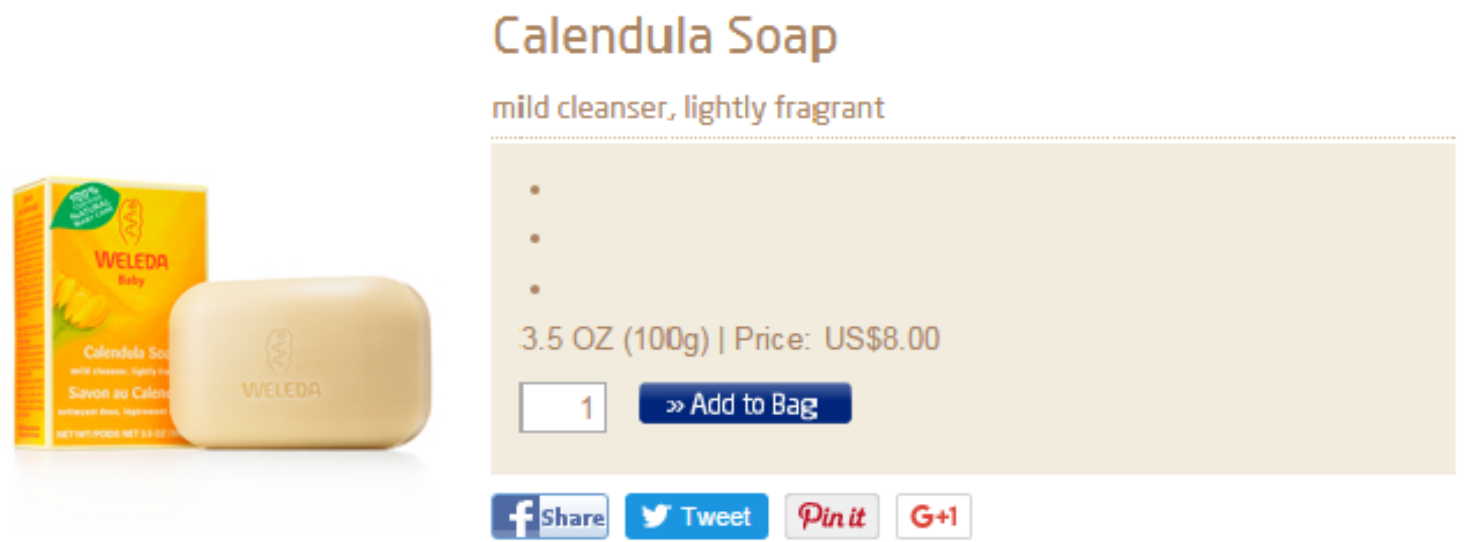

Description Customer Reviews Key Ingredients Ingredients In The Press

mild cleanser, lightly fragrant

Weleda Calendula Soap

Weleda Calendula Soap is a gentle bar cleanser for baby's bathtime

Baby's delicate skin gets mild cleansing with this all natural baby bath soap. Our Weleda Calendula Soap is a liehtly fragrant, moisture-balancing bar that's perfect for your baby's sensitive skin.

This all natural baby bath soap with extracts from nature to soothe and moisturize.

Weleda Calendula Soap is formulated with organic calendula flower extract and arganic chamomile flower extract to soothe your baby's skin and render it soft and supple. Organic iris root extract in this all natural baby bath soap balances the essential moisture of your baby's delicate skin. Your baby feels supple and soft to the touch after bathing with Weleda Calendula Soap, with balanced moisture that makes all the difference. Because moisture is not samething you want to come cut in the wash

\section{How to use}

Apply Calendula Soap to your wet hands or a wash cloth. Wash your baby's hands and/or body and rinse with clean water.

\section{Description Customer Reviews Key Ingredients Ingredients In The Press}

Description Customer Reviews Key Ingredients Ingredients In The Press

\footnotetext{
»Submit your product review!

Trenton W.

Posted: January 03, 2016

With all of the positive benefits that Calendula offers to the skin, one should think that Weleda would promote this soap for adult use as well. It actually is much better than their other cleansing products for the face. I've since dropped the facial milk and toner for this bar soap and face cream. The baby care range is not just for children, but for adults as well. Miss by far the best skin care range from Weleda, and that says a lot!
} 


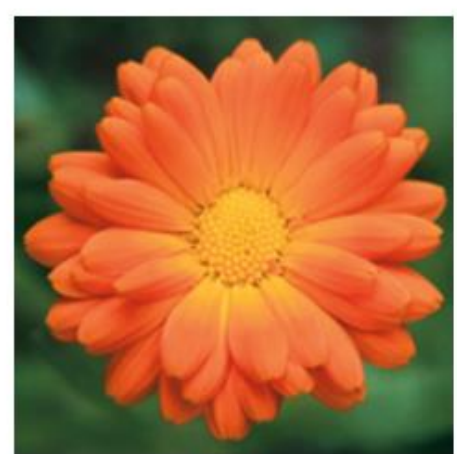

Calendula (Calendula Officinalis) Flower Extract

Commonly referred to as Marigold, this annual herb is from the Family Asteraceae, the Sunflower Family. The plant is native to central, eastern and southern Europe. It is made up of single, yellow to bright orange colored flowers that capture the strength and heat of the sun as it rises in the morning. The Calendula plant is comprised of carotenoids, flavonoids and essential oils. This gentle and nourishing botanical possesses powerful healing and antiinflammatory properties.

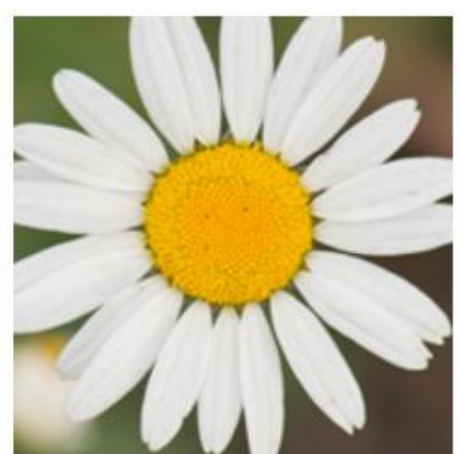

Chamomile (Chamomilla Recutita Matricaria) Flower Extract

This annual herb, also known as German Chamomile or Wild Chamomile, blooms small white flowers between May and August. It is found throughout Europe, except in the extreme north, and throughout northern Asia. The flowers of this plant possess gentle, healing and anti-inflammatory properties.

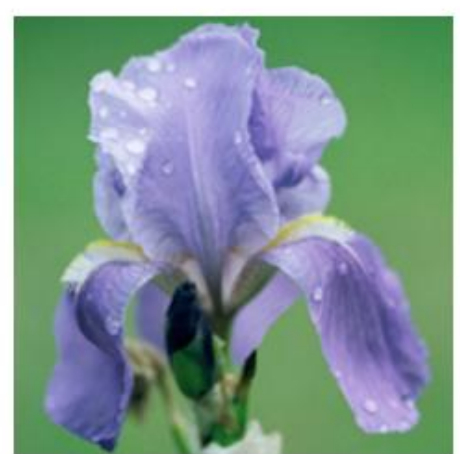

Iris (Iris Germanica) Root Extract

The resilient Iris plant is made up of a strong root system and stately flowers, generally of a violet hue. This plant possesses the unique ability to adapt to extreme environmental conditions, surviving in both desert and wetland areas. It is made up of special layers that protect it from drying, and each leaf has its own microclimate. The extract from the root, or rhizome, of the Iris stimulates the active layers of the skin and brings moisture and balance to the outer epidermal layers. It helps the skin look and feel healthy, soft and supple.

Ingredients (INCI)

Sodium Palmate, Sodium Cocoate, Water (Aqua), Sodium Olivate, Glycerin, Fragrance (Parfum)*, Limonene*, Linalool*, Citronellol*, Geraniol*, Calendula Officinalis Flower Extract, Chamomilla Recutita Matricaria (Chamomile) Extract, Iris Cermanica Root Extract, Viola Tricolor (Pansy) Extract, Oryza Sativa (Rice) Extract, Malt Extract, Sodium Chloride (Salt)

* from natural essential oils

Fonte: http://usa.weleda.com/our-products/shop/calendula-soap.aspx 


\subsubsection{Tradução}

Weleda Baby Sabonete de Calêndula

Limpeza suave, perfume leve.

O Weleda Baby Sabonete de Calêndula é um sabonete natural em barra, ideal para a hora do banho do bebê. Sua fórmula delicada contém extratos orgânicos de flor de calêndula e de flor de camomila, que promovem relaxamento, maciez e suavidade, além de extrato orgânico de raiz de íris, que equilibra a hidratação da pele delicada do bebê, afinal, hidratação é a última coisa que você quer que seja lavada durante o banho!

(a) Fragrância suave.

(b) Hidratação balanceada, ideal para a pele sensível dos bebês.

(c) Contém extratos orgânicos de flor de camomila e de calêndula, que têm efeito calmante e hidratam a pele do bebê.

Modo de uso:

Passe o Weleda Baby Sabonete de Calêndula nas mãos molhadas ou em uma esponja. Lave as mãos e/ou o corpo do bebê. Em seguida, enxágue com água corrente.

Advertências:

Este produto deve ser aplicado por adulto ou sob sua supervisão. Não usar na pele irritada ou lesionada. Em caso de irritação, suspender o uso e procurar um médico.

\section{Resenhas}

Trenton W

Postado em: 3 de janeiro de 2016. 
Com todos os benefícios que a Calêndula traz para a pele, poderiam pensar que a Weleda ia fazer propaganda desse sabonete também para os adultos. Ele é muito melhor do que os outros produtos de limpar o rosto. Já abandonei o leite de limpeza facial e o tonificante por este sabonete e pelo creme facial. A linha de cuidados com bebês não é só para criança, mas para adulto também. Deixa para trás os melhores produtos para a pele da Weleda, o que quer dizer muito!

Composição (INCI):

Sodium Palmate, Sodium $\quad$ Cocoate, Water $\quad$ (Aqua), Sodium Olivate, Glycerin, Fragrance (ParViola Tricolor (Pansy) Extract, Oryza Sativa (Rice) Extract, Malt $\quad$ Extract, Sodium $\quad$ Chloride (Salt)fum $)^{*}$, Limonene*, Linalool*, Citronellol*, Geraniol ${ }^{*}$, Calendula Officinalis Flower Extract, Chamomilla Recutita Matricaria (Chamomile) Extract, Iris Germanica Root Extract, .

* derivados de óleos essenciais naturais 


\subsubsection{Observações sobre a tradução}

A descrição do produto Weleda Baby Sabonete de Calêndula é extensa, bastante detalhada e enumera diversas qualidades do sabonete: "gentle bar", "delicate skin", "mild cleansing", "all natural baby bath soap", "lightly fragrant", "moisture-balancing bar", "sensitive skin" entre outros.

Considerou-se pertinente, portanto, consolidar as informações de forma a tornar o rótulo mais direto e objetivo. Uma opção foi fazer o uso de claims como: "fragrância suave"; "hidratação balanceada, ideal para a pele sensível dos bebês" e "contém extratos naturais, que promovem sensação de relaxamento e hidratam a pele do bebê" ("Our Weleda Calendula Soap is a lightly fragrant, moisture-balancing bar that's perfect for your baby's sensitive skin. This all natural baby bath soap with extracts from nature to soothe and moisturize").

Desta maneira, manteve-se o padrão aplicado nos produtos anteriores de reservar ao primeiro período uma descrição geral sobre a ação do produto: "O Weleda Baby Sabonete de Calêndula é um sabonete natural em barra delicado para a hora do banho do bebê". Em seguida, a fórmula é explorada bem como suas características específicas: ela é delicada, contém extratos orgânicos de flor de calêndula, de flor de camomila e de raiz de íris. As ações desses extratos também são destacadas: promovem relaxamento, maciez e suavidade, além de equilibrar a hidratação da pele do bebê.

Sobre o fato de a descrição do produto fazer menção aos ingredientes orgânicos, não há óbice em manter essa informação no texto traduzido. $O$ cenário se torna nebuloso quando o produto se diz orgânico, como visto anteriormente, porém não é o caso. No que concerne à aba Key Ingredients, não se considerou pertinente incluí-la na tradução do rótulo virtual em análise, tendo em vista que a minuciosidade da descrição dos três principais ingredientes do sabonete estão mais associados à propaganda do produto do que à segurança do consumidor. Ademais, na descrição do produto e na lista 
de ingredientes, já há menção à presença dos três ingredientes (flor de calêndula, flor de camomila e raiz de íris) no produto.

Para o modo de uso, foi empregado o modo imperativo, como de costume na comunidade de chegada: "espalhe", "lave" e "enxágue". De modo similar ao produto 3, washcloth foi traduzido por esponja. Com relação a apply, a opção de tradução foi "passe", tendo em vista ser mais comum "passar o sabonete" do que "aplicar o sabonete", ao menos no caso dos sabonetes em barra.

Sobre as advertências e sobre a resenha, permanecem as mesmas observações feitas para o produto anterior. Com relação à composição, a tradução deve manter os nomes na nomenclatura $\mathrm{INCl}$, como no rótulo virtual de referência. 


\section{CONSIDERAÇÕES FINAIS}

Estas últimas considerações refazem o percurso traçado por este estudo. Ao longo dos capítulos que o constituem, buscou-se abordar aspectos considerados relevantes e que pudessem apontar para possíveis respostas aos questionamentos iniciais que, como pontuado na metodologia de pesquisa, redesenharam a todo tempo o caminho da pesquisa e geraram novos questionamentos. Nesse sentido, tem-se consciência de que este estudo apresenta seus limites, e que ainda há muito a ser discutido e abordado para que se possa chegar a conclusões mais assertivas acerca do tema.

No capítulo 1, dedicado ao referencial teórico, foi visto que este estudo está inserido no contexto da globalização, que surge das inovações científicas e tecnológicas e gera impactos em diversas outras áreas, entre elas nas línguas e na tradução. Entretanto, visto que a globalização não é um fenômeno que ocorre de modo isolado, foram abordados, ainda, aspectos concernentes à localização, vista de modo mais detalhado por constituir fenômeno premente quando da abordagem de novos mercados consumidores por empresas que desejam comercializar seus produtos em locales diferentes daqueles onde surgiram. Nesse contexto, em que a comunidade meta requer a localização de elementos de rotulagem a partir de estratégias como a troca de elementos textuais para melhor adequação do produto, insere-se a tradução-substituição. Como visto no capítulo 1, esta pesquisa apresenta mais um contexto em que esse conceito se aplica, porém, de certo surgirão novos estudos de gêneros textuais cuja tradução imprime a violação do original visando a um objetivo maior: a efetivação do alcance de sua função, antes inviabilizado pela língua estrangeira.

Um segundo momento do capítulo 1 ocupa-se da revisão da legislação atinente especialmente ao Código de Defesa do Consumidor e à legislação sanitária no que concerne ao comércio eletrônico. Com relação ao CDC, viu-se que atualmente há um debate sobre a atualização do diploma legal para acrescentar-Ihe um capítulo a respeito do comércio eletrônico. Entretanto, há especialistas que não reconhecem a necessidade de atualização do Código, 
pois segundo eles, o "e-consumidor" já é amparado pelo atual texto. De todo modo, sendo atualizado ou não, o CDC garante ao consumidor, de modo geral, o acesso a informações essenciais sobre os produtos que deseja adquirir, incluindo elementos sobre os riscos à saúde do consumidor e à sua segurança; e que a oferta de produtos seja em língua portuguesa, inclusive a de importados, o que indica a premência de tradução. Foi visto, ainda, que a proposta de modernização do CDC não é a única iniciativa do Estado no sentido de proteger o consumidor diante da revolução causada pelas plataformas de comércio eletrônico. Muito pouco se encontrou, entretanto, de orientações e/ou normas substanciais da ANVISA a respeito dessa modalidade de comércio no que concerne aos cosméticos, inclusive infantis.

Assim, embora cumpram papel similar ao dos rótulos físicos, os rótulos virtuais ainda carecem de mecanismos de regulação e de fiscalização do ponto de vista da tradução. No momento atual, não se acredita que a disponibilização de informações com a rigidez requerida pela ANVISA para os rótulos físicos será realidade nos ambientes virtuais de compras, e tem-se consciência de que o tradutor é apenas mais um agente nessa cadeia, que envolve diversos outros interesses.

Entretanto, acredita-se que o tradutor, desde que disponha de informações elementares para o consumo seguro e consciente, deve optar pela prestação dessas informações ao consumidor de modo objetivo e preciso. Nesse cenário, ele deve se atentar a todas as nuanças que emolduram a tradução desse gênero textual em tela, de forma a produzir um texto que seja capaz de melhorar as relações de consumo na internet, atuando como agente de transformação dos ambientes virtuais.

O capítulo 3 apresentou o mercado de cosméticos infantis, bem como seu crescimento ao longo dos últimos anos especialmente no Brasil. Foram abordados fatores que podem contribuir para o aumento do consumo de produtos dessa categoria no país, a exemplo da diminuição do número de filhos por mulher e do aumento do turismo internacional, o que perpassa as trocas comerciais entre diferentes países na era da globalização. O capítulo tratou, também, da evolução da embalagem como principal meio de informação 
ao consumidor no momento da compra - por meio do rótulo -, o que culminou no meio virtual, onde não há mais contato com o rótulo físico no momento da compra. Abordaram-se, ainda, as mudanças na maneira de consumir e de se informar sobre o que consumir na era digital, destacando-se o papel do comércio eletrônico e da tradução nesse cenário de transformações. Nesse sentido, conclui-se que os fabricantes e comerciantes devem cuidar para que seus espaços virtuais subsidiem os consumidores com informações similares àquelas encontradas nos rótulos físicos dos produtos.

O capítulo 4 refletiu sobre a definição de rótulo. Viu-se que, no ambiente virtual, a concepção de rótulo considerada senso comum não satisfazia esta pesquisa, razão pela qual foi verificado que novos mecanismos de oferta, de publicidade e de informações sobre os produtos precisam ser desenvolvidos, regulados e traduzidos. Propôs-se, então, uma nova definição para rótulos, com vistas principalmente a abranger o conteúdo que é disponibilizado sobre os produtos cuja oferta ocorre em meio virtual, não apenas físico. Concluiu-se que, embora continuem existindo, os rótulos físicos não mais servem às relações sociais de compra e venda que o comércio eletrônico estabeleceu na internet, o que despontou a necessidade de definição do rótulo virtual e de sua percepção como um novo gênero textual sobre o qual se devia refletir, porém sempre que possível lançando mão do gênero textual rótulo físico, do qual aquele é oriundo.

No capítulo 5, foram explorados os papeis do rótulo como fonte de informação, como identidade do produto e como difusor de valores culturais, na medida em que o rótulo se tornou vendedor exclusivo em muitos ambientes comerciais e que, portanto, cabe ao tradutor observar todas as mensagens que esses textos transmitem, a fim de produzir traduções que permitam ao consumidor da comunidade meta decidir sobre sua compra de maneira segura e satisfatória, ou seja, para que os rótulos cumpram, para os consumidores de chegada, a mesma função que cumprem para os consumidores de partida.

O capítulo 6, por fim, se ocupou da análise de rótulos virtuais de cosméticos infantis fabricados no Brasil e aqui comercializados via lojas 
virtuais, da descrição dos principais elementos físicos e linguísticos dessa nova rotulagem, a fim de subsidiar a produção de traduções de rótulos virtuais de cosméticos infantis importados e comercializados no Brasil. Nesse capítulo foram apresentadas, também, propostas de traduções que subsidiem melhor os consumidores online no momento de suas compras, a partir de textos autênticos desse mesmo gênero textual. Considerações finais mais pontuais sobre a análise e a aplicação foram tecidas ao longo do próprio capítulo 6 .

Encerra-se com a ciência de que muitos problemas foram levantados e que poucas soluções foram apontadas. Os desafios apresentados nesta pesquisa requerem, de certo, novas soluções, algumas das quais começaram a emergir apenas agora. É evidente que as afirmações neste estudo não devem ser encaradas como teses prontas e acabadas, mas sim como aspectos sobre os quais possa ser interessante refletir.

Espera-se que este estudo possa contribuir com o trabalho de tradutores de rótulos de cosméticos virtuais infantis, que, diante de tantas nuanças e opções, deverão construir seu próprio caminho que pode ter, nesta pesquisa, um ponto de partida. Espera-se, ainda, que este estudo enriqueça o debate sobre todas as questões que ele implica, sobretudo no que diz respeito à sua real inserção na realidade em que se vive. 
REFERÊNCIAS

AGÊNCIA NACIONAL DE VIGILÂNCIA SANITÁRIA. Parecer Técnico no 5 da Câmara Técnica de Cosméticos - CATEC/ANVISA, de 28 de setembro de 2001. Uso do termo "hipoalergênico" em produtos de higiene pessoal, cosméticos e perfumes. Disponível em: <http://www.ANVISA.gov.br/cosmeticos/informa/parecer_hipo.htm>. Acesso em: 16 fev. 2016.

ASSOCIAÇÃO BRASILEIRA DA INDÚSTRIA DE HIGIENE PESSOAL, PERFUMARIA E COSMÉTICOS (ABIHPEC). Panorama do Setor de HPPC de 2015. Disponível em: <https://www.abihpec.org.br/novo/wp-content/uploads/2015-PANORAMA-DO-SETORPORTUGU\%C3\%8AS-11ago2015.pdf>; Acesso em: 11 dez. 2015.

ASSOCIAÇÃO BRASILEIRA DE EMBALAGEM. A embalagem. Disponível em: <http://www.abre.org.br/setor/apresentacao-do-setor/a-embalagem/>. Acesso em: 30 abr. 2015.

BARRY JONES, R.J. Introduction: the problem of globalization. In: BARRY JONES, R.J. The World Turned Upside Down? Globalization and the future of the state. Manchester and New York: Manchester University Press, 2000.

BENJAMIN, A. H.V. Relatório sobre o Projeto de Lei do Senado n.ำ 281, de autoria do Senador José Sarney, que altera a Lei n... 8.078, de 11 de setembro de 1990 (Código de Defesa do Consumidor). Disponível em:

http://www25.senado.leg.br/web/atividade/materias/-/materia/106768; Acesso em: 20 fev. 2016.

BOAVENTURA, G. O difícil mercado de cosméticos orgânicos e naturais brasileiro. 2014. Disponível em: http://www.cosmeticaemfoco.com.br/2014/08/o-dificilmercado-de-cosmeticos-organicos-e-naturais-brasileiro.html\#axzz3yYhnVYvl. Acesso em: 28 jan. 2016.

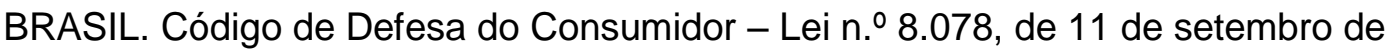
1990. Dispõe sobre a proteção do consumidor e dá outras providências. Brasília, Fernando Collor de Melo, Presidente da República, 11 set. 1990.

BRASIL. Estatuto da Criança e do Adolescente - Lei n.. 8.069, de 13 de julho de 1990. Dispõe sobre o Estatuto da Criança e do Adolescente e dá outras providências. Brasília, Fernando Collor de Melo, Presidente da República, 13 jul. 1990.

BRASIL. Ministério da Saúde. Portaria n.ำ 42, de 14 de janeiro de 1998. Aprova o Regulamento Técnico para Rotulagem de Alimentos Embalados constante do Anexo desta Portaria. Disponível em: http://portal.anvisa.gov.br/wps/wcm/connect/115381804745970b9f55df3fbc4c6735/PO RTARIA_42.pdf?MOD=AJPERES. Acesso em: $11 \mathrm{dez} .2015$. 
BRASIL. Ministério do Turismo. Destinos turísticos brasileiros são divulgados nos

EUA. Disponível em: <http://www.brasil.gov.br/turismo/2015/12/destinos-turisticosbrasileiros-sao-divulgados-nos-eua>; Acesso em: $11 \mathrm{dez} .2015$.

BRASIL. Ministério do Turismo. EUA são o destino favorito dos brasileiros. Portal Brasil. Disponível em: <http://www.brasil.gov.br/turismo/2015/06/eua-sao-o-destinofavorito-de-turistas-brasileiros>; Acesso em: $11 \mathrm{dez} .2015$.

BRASIL. Resolução (RDC) ANVISA/MS n. 4, de 30 de janeiro de 2014. Dispõe sobre os requisitos técnicos para a regularização de produtos de higiene pessoal, cosméticos e perfumes e dá outras providências. Disponível em:

http://portal.anvisa.gov.br/wps/wcm/connect/e321990042cf06e79b57dfafbc188c8f/Res olu\%C3\%A7\%C3\%A3o+RDC+n\%C2\%BA+4+de+30+\%20de+janeiro+de+2014.pdf?M OD=AJPERES. Acesso em: 22 jan. 2016.

BRASIL. Resolução (RDC) ANVISA/MS n.ำ 15, de 24 de abril de 2015. Dispõe sobre os requisitos técnicos para a concessão de registro de produtos de higiene pessoal, cosméticos e perfumes infantis e dá outras providências. Disponível em:

http://portal.anvisa.gov.br/wps/wcm/connect/523f6980486e9bb7bed8bf734e60b39c/RD $\mathrm{C}+\mathrm{N} \% \mathrm{C} 2 \% \mathrm{BA}+15,+\mathrm{DE}+24+\mathrm{DE}+\mathrm{ABRIL}+\mathrm{DE}+2015$.pdf?MOD=AJPERES. Acesso em: 23 jan. 2016.

BRASIL. Resolução (RDC) ANVISA/MS n. 79, de 28 de agosto de 2000. Dispõe sobre a definição e classificação dos produtos de higiene pessoal, cosméticos e perfumes e outros com abrangência nesse contexto e dá outras providências. Disponível em: http://www.anvisa.gov.br/cosmeticos/guia/html/79_2000.pdf. Acesso em: 22 jan. 2016.

BRASIL. Resolução (RDC) ANVISA/MS n. 211, de 14 de julho de 2005. Estabelece a definição e a classificação dos produtos de higiene pessoal, cosméticos e perfumes, conforme anexo I e II desta Resolução e dá outras providências. Disponível em: http://portal.anvisa.gov.br/wps/wcm/connect/dfa9b6804aee482bb7a1bfa337abae9d/Re solu\%C3\%A7\%C3\%A3o+RDC+n\%C2\%BA+211,+de+14+de+julho+de+2005.pdf?MOD $=$ AJPERESAcesso em: 22 jan. 2016 .

BRASIL. Resolução (RDC) ANVISA/MS n.ำ 259, de 20 de setembro de 2002. Aprova o regulamento técnico sobre rotulagem de alimentos embalados. Disponível em: file://C:/Users/Raquel/Downloads/resoluo\%20rdc\%20n\%20259\%202002\%20\%20rotulagem\%20em\%20geral.pdf. Acesso em: 22 jan. 2016.

Budweiser muda de logo e embalagem em nova fase. Disponível em: http://exame.abril.com.br/marketing/noticias/budweiser-muda-de-logo-e-embalagemem-nova-fase\#2. Acesso em: 23 fev. 2016.

CADIEUX, P; ESSELINK, B. GILT: Globalization, Internationalization, Localization and Translation, 2009. Disponível em: http://www.translationdirectory.com/article127.htm. Acesso em: 11 nov. 2015.

CARVALHO, T.J. O comércio eletrônico e o Código de Defesa do Consumidor na nova ordem contratual: o e-commerce enquanto relação de consumo. In: Âmbito Jurídico, Rio Grande, XV, n. 98, mar 2012. Disponível em: <http://www.ambito- 
juridico.com.br/site/?n_link=revista_artigos_leitura\&artigo_id $=11283 \&$ revista_caderno= 10>. Acesso em: 25 fev. 2016.

CANESCHI et al. Análise de rotulagem de produtos fotoprotetores. In: Revista Brasileira de Farmácia. Rev. Bras. Farm. 92(3): 208-212, 2011. Disponível em: http://www.rbfarma.org.br/files/rbf-2011-92-3-21.pdf. Acesso em: 09 dez. 2015.

CRONIN, M. Translation and globalization. London; New York: Routledge, 2003.

DIGIÁCOMO, M.J; DIGIÁCOMO, I.A. Estatuto da criança e do adolescente anotado e interpretado. Ministério Público do Estado do Paraná. Centro de Apoio Operacional das Promotorias da Criança e do Adolescente. Curitiba: 2013, 6ª edição. Disponível em:

http://www.crianca.mppr.mp.br/arquivos/File/publi/caopca/eca_anotado_2013_6ed.pdf. Acesso em: 25 fev. 2016.

DOMENICI, T. O boom do e-commerce. Retrato do Brasil, São Paulo, n. 84, jul. 2014. Disponível em: <http://www.blogdaretrato.com.br/2014/08/o-boom-do-ecommerce.html>. Acesso em: 14 dez. 2015.

ESTEVES, et al. Os sufixos de grau e a polissemia sufixal: análise dos sufixos - ão e -inho no texto publicitário. 2012. Disponível em:

http://www.letras.ufscar.br/linguasagem/edicao19/artigosic/artigo_ic_005.pdf. Acesso em: 15 fev. 2016.

Famosa marca de protetor labial é processada após provocar feridas na boca dos clientes. Disponível em: http://vejasp.abril.com.br/blogs/pop/2016/01/13/eos-protetorlabial-

rocesso/?utm_source=redesabril_vejasp\&utm_medium=facebook\&utm_campaign=vej asp. Acesso em: 13 jan. 2016.

FREITAS, T. Sem regulação, país é coadjuvante em cosméticos orgânicos. In: Folha de São Paulo. 2014. Disponível em:

http://www1.folha.uol.com.br/mercado/2014/03/1429457-sem-norma-pais-ecoadjuvante-em-cosmeticos-organicos.shtml. Acesso em: 28 jan. 2014.

FUNDAÇÃO DE PROTEÇÃO E DEFESA DO CONSUMIDOR - Procon/SP. Guia Comércio Eletrônico. 2014. Disponível em:

http://www.procon.sp.gov.br/pdf/GuiadeComercioEletronico62014.pdf. Acesso em: 25 fev. 2016.

GOLDENBERG, P. O guia do enxoval do bebê nos Estados Unidos: dicas e segredos da maior especialista de compras em Miami, Orlando e Nova York. Panda Books, 2014.

MAIA, J. F. S; DAMASCENO, L. A da L. As novas regras para o comércio eletrônico. Disponível em: http://www.migalhas.com.br/dePeso/16,Ml180305,11049As+novas+regras+para+o+comercio+eletronico. Acesso em: 25 fev. 2016.

MARTINS, E. G.; BORGHI, C. I. B. O gênero textual "rótulos de embalagens" como instrumento de ensino aprendizagem da leitura em língua inglesa. Disponível em: 
http://www.gestaoescolar.diaadia.pr.gov.br/arquivos/File/producoes_pde/artigo_evanild e_gimenez_martins.pdf; acesso em: 14 jan. 2016

MARCUSCHI, L. A. Linearização, cognição e referência: o desafio do hipertexto. In: Línguas e instrumentos linguísticos. Campinas/SP: Editora Pontes, 1999, pp. 21 46.

Gêneros textuais: configuração, dinamicidade e circulação. In:

KARWOSKI, A.C; GAYDECZKA, B.; BRITO, K. S (Orgs.). Gêneros textuais: reflexões e ensino. Palmas e União da Vitória, PR: Kaygangue, 2005.

Gêneros textuais: definição e funcionalidade. In: DIONISIO, A. P. et al.

(Orgs.). Gêneros textuais \& ensino. Rio de Janeiro: Lucerna, 2002.

- Gêneros textuais emergentes no contexto da tecnologia digital. In:

MARCUSCHI, L.A. XAVIER, A. C. (Orgs.). Hipertexto e gêneros digitais - Novas formas de construção de sentido. Rio de Janeiro: Lucerna, 2004.

MENDONÇA, R. Rótulos e etiquetas: atração visual e sensorial. Cosmética News. 2013. Disponível em: http://www.cosmeticanews.com.br/leitura.php?n=rotulos-eetiquetas-atracao-visual-e-sensorial\&id=4429. Acesso em: 27 jan. 2016.

MINTEL. Setor de comércio eletrônico no Brasil cresceu $250 \%$ nos últimos cinco anos. 2014. Disponível em:<http://brasil.mintel.com/imprensa/varejo-imprensa/setorde-comercio-eletronico-no-brasil-cresceu-250-nos-ultimos-cinco-anos>. Acesso em: 22 set. 2015.

O Gosto Brasil. Revista Superinteressante Disponível em:

http://super.abril.com.br/comportamento/o-gosto-brasil; Acesso em: 02 mar. 2016.

ORGANIZAÇÃO MUNDIAL DO TURISMO (OMT). Panorama OMT del turismo internacional, edición 2015. Disponível em: <http://www.eunwto.org/doi/pdf/10.18111/9789284416875>; Acesso em: $11 \mathrm{dez} .2015$.

PELLEGRINO, L. A embalagem. Disponível em: <http://www.abre.org.br/setor/apresentacao-do-setor/a-embalagem/>. Acesso em: 30 abr. 2015.

PESSOA, M. N. A tradução-substituição. Belas Infiéis: Revista do Programa de PósGraduação em Estudos da Tradução da UnB, Brasília, v. 4, n. 1, p. 233-237, 2015.

PYM, A. Globalization and the Politics of Translation Studies. Meta: Translators' Journal, vol. 51, $n^{\circ} 4$, p. 744-757, 2006. Disponível em: https://www.erudit.org/revue/meta/2006/v51/n4/014339ar.pdf; Acesso em: 01 mar. 2016

Localization: on its nature, virtues and dangers. 2005. Disponível em: http://usuaris.tinet.cat/apym/on-line/translation/translation.html. Acesso em: 01 mar. 2016.

Negotiating the frontier: translations and intercultures in Hipanic history. Manchester: St. Jerome Publishing, 2000. 
ROSCOE-BESSA, C. A tradução de rótulos de comestíveis e cosméticos. Brasília: Universidade de Brasília, 2000.

A tradução de rótulos de comestíveis e cosméticos. Brasília:

Universidade de Brasília, Instituto de Letras, Plano, 2003.

; AQUINO, J. S; BORGES, R. B. de O. O local e o universal na

tradução de produtos cosméticos e comestíveis. Rio de Janeiro: 7 Letras, 2014.

São Paulo, 2006.

Tradução explícita e tradução velada. São Paulo: Universidade de

A tradução-substituição. Brasília: Editora do Centro, 2010.

ROTURIER, J. Localizing Apps: a practical guide for translators and translation stu dies. New York: Routledge, 2015.

SABBATINI, R. M.E. Internet, globalização e cultura. Jornal Correio Popular, Campinas, 1996. Disponível em:

http://www.sabbatini.com/renato/correio/corr9656.htm. Acesso em: 04 mar. 2016.

SAMPAIO, I. S. V. Discursos da criança na publicidade. In: SAMPAIO, I. S. V.

Televisão, publicidade e infância. São Paulo: Annablume; Fortaleza: Secretaria de Cultura e Desporto do Estado do Ceará, 2000.

SÃO JERÔNIMO. Obras de São Jerônimo. Edição dos Beneditinos, 1693, t. It. Col. 1425.

SCATOLIM, R. L. A importância do rótulo na comunicação visual da embalagem: uma análise sinestésica do produto. 2008. São Paulo. Disponível em:

http://www.bocc.ubi.pt/pag/scatolim-roberta-importancia-rotulo-comunicacao.pdf.

Acesso em: 10 dez. 2015.

SCHÄFFNER, C. Introduction: Globalisation, Communication, Translation. In: SCHÄFFNER, C (Org.). Translation in the global village, 2000.

SERVIÇO BRASILEIRO DE APOIO ÀS MICRO E PEQUENAS EMPRESAS

(SEBRAE). O que é uma loja virtual. In: Como abrir uma loja virtual. 2011.

Disponível em:

http://www.bibliotecas.sebrae.com.br/chronus/ARQUIVOS_CHRONUS/bds/bds.nst/CB 2C58620CEC8329832579BB004A7969/\$File/NT0004749A.pdf. Acesso em: 05 fev.

2016.

O que você precisa saber sobre o comércio eletrônico. Disponível

em: http://www.sebrae.com.br/sites/PortalSebrae/sebraeaz/O-que-voc\%C3\%AA-

precisa-saber-sobre-com\%C3\%A9rcio-eletr\%C3\%B4nico. Acesso em: 14 dez. 2015.

SHIYAB, S. M. Globalization and its impact on translation. In: SHIYAB, S. M.; ROSE, M. G.; HOUSE, J.; DUVAL, J. Globalization and aspects of translation. United Kingdom: Cambridge Scholars Publishing, 2010, pp. 1-10 
STONE, B. A loja de tudo: Jeff Bezos e a era da Amazon. São Paulo: Intrinseca, 2014.

TEIXEIRA, M. A. EUA propõem nova rotulagem para embalagem de alimentos: mudança dá destaque às calorias e reflete o tamanho real das porções. O Globo. 2014. Disponível em: http://oglobo.globo.com/sociedade/saude/eua-propoem-novarotulagem-para-embalagem-de-alimentos-11742222. Acesso em: 27 jan. 2016.

UNITES STATES FOOD AND DRUG ADMINISTRATION. Shelf Life/Expiration Dating. 2002. Disponível em:

http://www.fda.gov/Cosmetics/Labeling/ExpirationDating/ucm2005204.htm. Acesso em: 29 jan. 2016.

UNITED STATES FOOD AND DRUG ADMINISTRATION. Are Some Cosmetics Promising Too Much? Disponível em:

http://www.fda.gov/ForConsumers/ConsumerUpdates/ucm439270.htm. Acesso em: 16 fev. 2016.

VIEIRA, A.C. P.; CORNÉLIO, A. R. Produtos light e diet: o direito de informação ao consumidor. Âmbito Jurídico, Rio Grande, X, n. 45, set 2007. Disponível em:

$<$ http://www.ambito-

juridico.com.br/site/index.php?n_link=artigos_leitura_pdf\&artigo_id=2212.>. Acesso em: 28 jan. 2016. 
Anexos 


\title{
CATEGORIAS E GRUPOS DE PRODUTOS INFANTIS
}

\section{I - Produtos de Higiene Pessoal}

a) Condicionador com enxágüe

b) Condicionador sem enxágüe

c) Dentifrício com Flúor

d) Dentifrício sem Flúor

e) Desodorante Axilar

f) Desodorante Pédico

g) Enxaguatório bucal com Flúor com ou sem ação antisséptica

h) Enxaguatório bucal sem Flúor com ou sem ação antisséptica

i) Óleo capilar/corporal

j) Pó corporal (Talco/Amido)

k) Produto de limpeza/ higienização

I) Sabonete

m) Xampu para cabelo e/ou corpo

\section{II - Cosméticos}
a) Batom e brilho labial
b) Blush/Rouge
c) Esmalte para as unhas
d) Fixador de cabelos
e) Hidratante para a pele
f) Maquiagem capilar/corporal
g) Máscara capilar
h) Pó facial
i) Produto para inibir o hábito de roer unhas
j) Produto para prevenir assaduras

\author{
k) Produto pós-sol \\ l) Protetor Labial com FPS \\ m) Protetor Labial sem FPS \\ n) Protetor solar \\ o)Reparador de pontas para os \\ cabelos \\ p) Repelente de insetos \\ q) Sombra
}

III - Perfumes

a) Água de colônia

b) Perfume 


\section{ANEXO B - HIPERLINK “CHEGA DE LÁGRIMAS ${ }^{\circledR}$ ”}

\section{JOHNSON'S ${ }^{\circledR}$ baby Chega de Lágrimas ${ }^{\circledR}$}

Na Johnson \& Johnson, estabelecemos as diretrizes mais rigorosas para seguirmos.

Todos os nossos produtos da linha Chega de Lágrimas ${ }^{\circledR}$ são testados rigorosamente e precisam passar por quatro estágios antes que possam ser usados em uma criança. Se forem aprovados em todas estas etapas sequenciais, somente então serão produzidos para receber o selo de aprovação Chega de Lágrimas ${ }^{\circledast}$.

Os quatro estágios dos testes Chega de Lágrimas ${ }^{\circledR}$

1. Revisão dos ingredientes e da formulação.Cada um de nossos ingredientes e a formulação combinada são todos rigorosamente avaliados quanto à segurança.

2. Avaliação de segurança pré-clínica. Para garantir a segurança, nossos grupos de segurança examinam profundamente estes produtos em um laboratório.

3. Testes clínicos oculares. Um oftalmologista certificado por conselho realiza mais de 150 avaliações clínicas nos produtos Chega de Lágrimas ${ }^{\circledR}$.

4. Revisäo médica. Realizamos uma revisão detalhada de todos os dados para garantir a segurança ocular.

Um profundo entendimento dos olhos do bebê

Ninguém entende os olhos do bebê como entendemos. Na JOHNSON \& JOHNSON, temos plena consciência dos problemas em potencial causados quando outros produtos irritantes entram nos olhos do bebê.

- Os bebês não piscam muito. Em seu primeiro ano, é comum os bebês manterem seus olhos abertos durante um minuto inteiro, enquanto os adultos piscam mais ou menos a cada 11 segundos.

- O reflexo lacrimal dos bebês somente começa a ocorrer na semana 6 ou posterior de vida, quando as lágrimas podem acompanhar o choro.

- $\mathrm{O}$ pH da lágrima de um recém-nascido é um pouco mais ácido que o dos adultos, portanto, requer cuidado especial.

Nada deve atrapalhar você e seu bebê de aproveitar a hora do banho. É por isso que assumimos a responsabilidade de saber o máximo possivel sobre os preciosos olhos dos bebês Procure o selo Chega de Lágrimas ${ }^{\circledast}$ em seus produtos favoritos JOHNSON'S ${ }^{\circledast}$ baby Hora do Banho. 
APÊNDICES 
APÊNDICE A - PLANILHA (MARCA/FABRICANTE/TIPO DE PRODUTO)

\begin{tabular}{|c|c|c|c|c|c|c|c|c|c|c|c|c|c|c|c|c|c|c|}
\hline \multirow[b]{2}{*}{ Tipo de produto } & \multicolumn{18}{|c|}{ Marca } \\
\hline & Baruel $^{\star * *}$ & $\begin{array}{l}\text { Biotropic } \\
\text { cosmética* }^{*}\end{array}$ & $\begin{array}{l}\text { Cheirinho } \\
\text { de bebê }\end{array}$ & Cremer & Dermacyd & Dove & Fofo & Granado & $\begin{array}{l}\text { Huggies } \\
\text { Turma } \\
\text { da } \\
\text { Mônica }\end{array}$ & Johnsons & Lillo & Natura & Nazca & Nivea & boticário & Palmolive & Phisalia $^{\star \star}$ & $\begin{array}{l}\text { Pom } \\
\text { Pom }\end{array}$ \\
\hline água de colônia & & & & & & & & & & & & $x$ & & & $x$ & & $x$ & $\mathrm{x}$ \\
\hline bloqueador solar & & & & & & & & & $\mathrm{x}$ & & & & & & & & & \\
\hline condicionador & $\mathrm{x}$ & $\mathrm{x}$ & $\mathrm{x}$ & $\mathrm{X}$ & & $\mathrm{x}$ & & $x$ & $x$ & $x$ & $x$ & $x$ & $x$ & & & $x$ & $x$ & $x$ \\
\hline colônia & $x$ & $x$ & $x$ & $x$ & & $x$ & & & $x$ & $x$ & & $x$ & & & & & $x$ & \\
\hline $\begin{array}{l}\text { colônia para } \\
\text { cabelos }\end{array}$ & & & & & & & & & & $\mathrm{x}$ & & & & & & & & \\
\hline $\begin{array}{c}\text { creme para } \\
\text { assaduras }\end{array}$ & $\mathrm{x}$ & $\mathrm{x}$ & & $\mathrm{X}$ & & $\mathrm{x}$ & & $\mathrm{x}$ & $\mathrm{x}$ & & & & & & & & $\mathrm{x}$ & $\mathrm{x}$ \\
\hline $\begin{array}{l}\text { creme para } \\
\text { pentear }\end{array}$ & $x$ & $x$ & $x$ & & & & & & & $x$ & & & $x$ & & & $x$ & $x$ & \\
\hline gel dental & & & & & & & & & & & & & & & & & $x$ & \\
\hline gel para cabelos & $\mathrm{x}$ & $\mathrm{x}$ & & & & & & & & & & & & & & & $\mathrm{x}$ & \\
\hline gel pós sol & & & & & & & & & $x$ & & & & & & & & & \\
\hline hidratante & $\mathrm{X}$ & $\mathrm{x}$ & $\mathrm{x}$ & & & $\mathrm{x}$ & & $\mathrm{x}$ & $\mathrm{x}$ & $\mathrm{x}$ & & $\mathrm{x}$ & & & & & & \\
\hline higiapele & & & & & & & & & & $\mathrm{x}$ & & & & & & & & \\
\hline lavanda & $x$ & & & $\mathrm{X}$ & & & & & & $x$ & & & & & & & $x$ & \\
\hline lenços umedecidos & & $\mathrm{x}$ & & & & & & $\mathrm{x}$ & $\mathrm{x}$ & $\mathrm{x}$ & & $\mathrm{x}$ & & & & & $\mathrm{x}$ & \\
\hline loção antimosquito & & & & & & & & & & $x$ & & & & & & & & \\
\hline $\begin{array}{l}\text { máscara de } \\
\text { hidratação }\end{array}$ & & $\mathrm{x}$ & & & & & & & & & & & & & & & $\mathrm{x}$ & \\
\hline óleo & $\mathrm{x}$ & $\mathrm{x}$ & & $\mathrm{x}$ & & & & $\mathrm{x}$ & & $\mathrm{x}$ & & $\mathrm{x}$ & & & $\mathrm{x}$ & & & \\
\hline polvilho & $x$ & & & & & & & & & & & & & & & & & \\
\hline protetor solar & & & & & & & & & & & & $\mathrm{x}$ & & $\mathrm{x}$ & $\mathrm{x}$ & & & \\
\hline repelente & & & & & & & & & $\mathrm{x}$ & & & & & & & & & \\
\hline sabonete em barra & $\mathrm{x}$ & $\mathrm{x}$ & $\mathrm{x}$ & $\mathrm{X}$ & & $\mathrm{x}$ & & & $\mathrm{x}$ & $\mathrm{x}$ & & $\mathrm{x}$ & & & $\mathrm{x}$ & & $\mathrm{x}$ & $\mathrm{x}$ \\
\hline sabonete espuma & & & & & & & & & & & & & & & & & & $\mathrm{x}$ \\
\hline sabonete líquido & $\mathrm{x}$ & $x$ & $\mathrm{x}$ & $\mathrm{x}$ & $\mathrm{x}$ & $\mathrm{x}$ & $x$ & $x$ & $x$ & $x$ & $x$ & $x$ & & & $x$ & & $x$ & \\
\hline spray para cabelos & & & & & & & & & $x$ & & & & & & & & & \\
\hline $\begin{array}{c}\text { spray } \\
\text { desembaraçante }\end{array}$ & & & & & & & & & & & & & & & & & $x$ & $\mathrm{x}$ \\
\hline talco & & $\mathrm{x}$ & $\mathrm{x}$ & $\mathrm{X}$ & & & & $\mathrm{x}$ & & $\mathrm{x}$ & & & & & & & $\mathrm{x}$ & $\mathrm{x}$ \\
\hline talco em creme & & $\mathrm{x}$ & & & & & & & & & & $\mathrm{x}$ & & & & & & \\
\hline
\end{tabular}




\begin{tabular}{|c|c|c|c|c|c|c|c|c|c|c|c|c|c|c|c|}
\hline $\begin{array}{c}\text { toalhas } \\
\text { umedecidas }\end{array}$ & & $x$ & & $\mathrm{X}$ & & & $x$ & & & & & & & $x$ & $\underline{x}$ \\
\hline $\begin{array}{c}\text { umidificador de } \\
\text { cachos }\end{array}$ & & & & & & & & & & & $x$ & & & & \\
\hline xampu & $x$ & $x$ & $x$ & $x$ & $x$ & $x$ & $x$ & $x$ & $x$ & $x$ & $x$ & $x$ & $x$ & $x$ & $\mathrm{x}$ \\
\hline
\end{tabular}

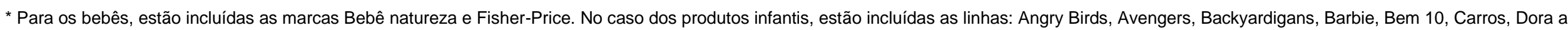
aventureira, Fadas (Disney), Adventure Time, Hot Wheels, Mickey Mouse, Minions, Monster High, Phineas and Ferb, Polly pocket, Princesa (Disney), Star Wars, Teenage Mutant Turtles e Spider-Man

** linhas: Patati Patatá; Transformers; Trá lá lá Kids; Trá lá lá baby; Ni Hao, Kai-Lan e Lukinha

*** linhas: Turma da xuxinha; Aviões (Disney); Princesa (Disney); Frozen (Disney);

$\mathrm{O}$ "x" na coluna relativa à marca, indica que ela fabrica o tipo de produto especificado na coluna $\mathrm{A}$ 


\section{APÊNDICE B - TABELA COMPARATIVA ENTRE OS RÓTULOS FíSICO E VIRTUAL DO PRODUTO JOHNSON'S BABY SHAMPOO HORA DO SONO}

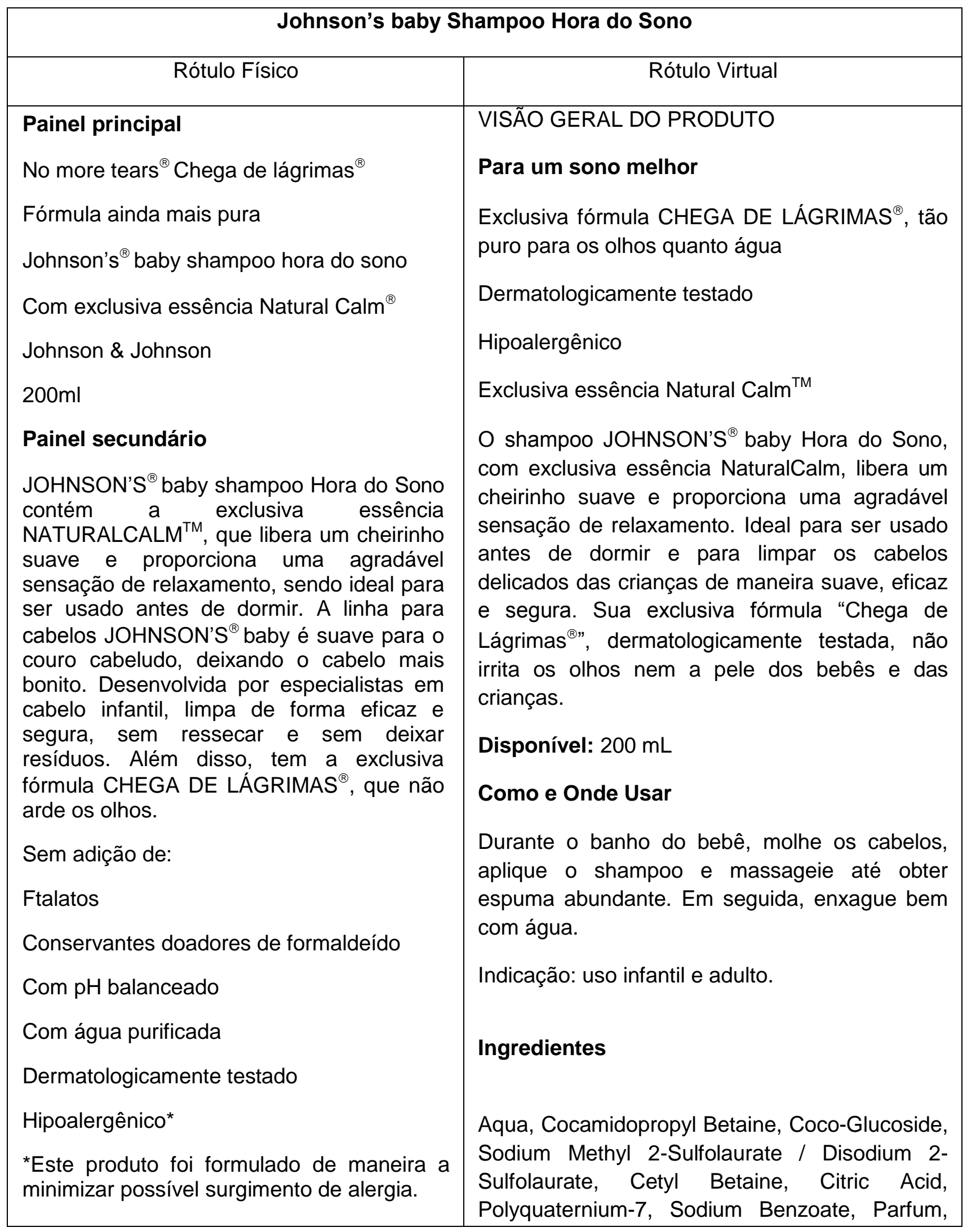


JOHNSON'S ${ }^{\circledR}$ baby - Aprovado por mães de todo o mundo. Conheça também a linha completa de produtos JOHNSON'S ${ }^{\circledR}$ baby Hora do Sono, que usados na rotina diária, comprovadamente ajudam o bebê a dormir melhor e mais rápido. ${ }^{* * *}$

${ }^{* * *}$ Estudos científicos realizados no laboratórioda J\&J nos EUA. Os resultados foram obtidos com base na rotina de banho e pós banho do bebê.

Modo de uso: Aplique nos cabelos, massageando suavemente. Em seguida, enxágue com água.

Precauções: Mantenha fora do alcance de crianças. Evitar contato com os olhos. Deve ser aplicado por adulto ou sob sua supervisão. Não usar se o couro cabeludo estiver lesado ou irritado. Em caso de irritação, suspender o uso e procurar um médico. Conservar em local seco, fresco e ao abrigo de luz solar direta.

Composição: Aqua, Cocamidopropyl Betaine, Coco-Glucoside, Sodium Methyl 2Sulfolaurate / Disodium 2-Sulfolaurate, Cetyl Betaine, Citric Acid, Polyquaternium-7, Sodium Benzoate, Parfum, Tetrasodium EDTA, Cl 17200, Cl 42090.

Prazo de Validade (mês/ano) e Lote: vide indicação na embalagem.

Care to Recycle ${ }^{\mathrm{TM}}$

Por favor, recicle

Fabricado por:

JOHNSON \& JOHNSON INDUSTRIAL LTDA.

Rod. Presidente Dutra, km 154

São José dos Campos - SP

C.N.P.J. 59.748.988/0001-14

Indústria Brasileira
Tetrasodium EDTA, Cl 17200, Cl 42090

\section{Dica de Segurança}

Mantenha fora do alcance das crianças 
APÊNDICE C - TABELA COMPARATIVA ENTRE OS RÓTULOS FÍSICO E VIRTUAL DO SABONETE LÍQUIDO da CabeÇa aos PÉs HidRataçÃo EnRIQueCida (Dove)

\begin{tabular}{|c|c|}
\hline \multicolumn{2}{|c|}{ Sabonete Líquido da Cabeça aos Pés Hidratação Enriquecida } \\
\hline Rótulo Físico & Rótulo Virtual \\
\hline 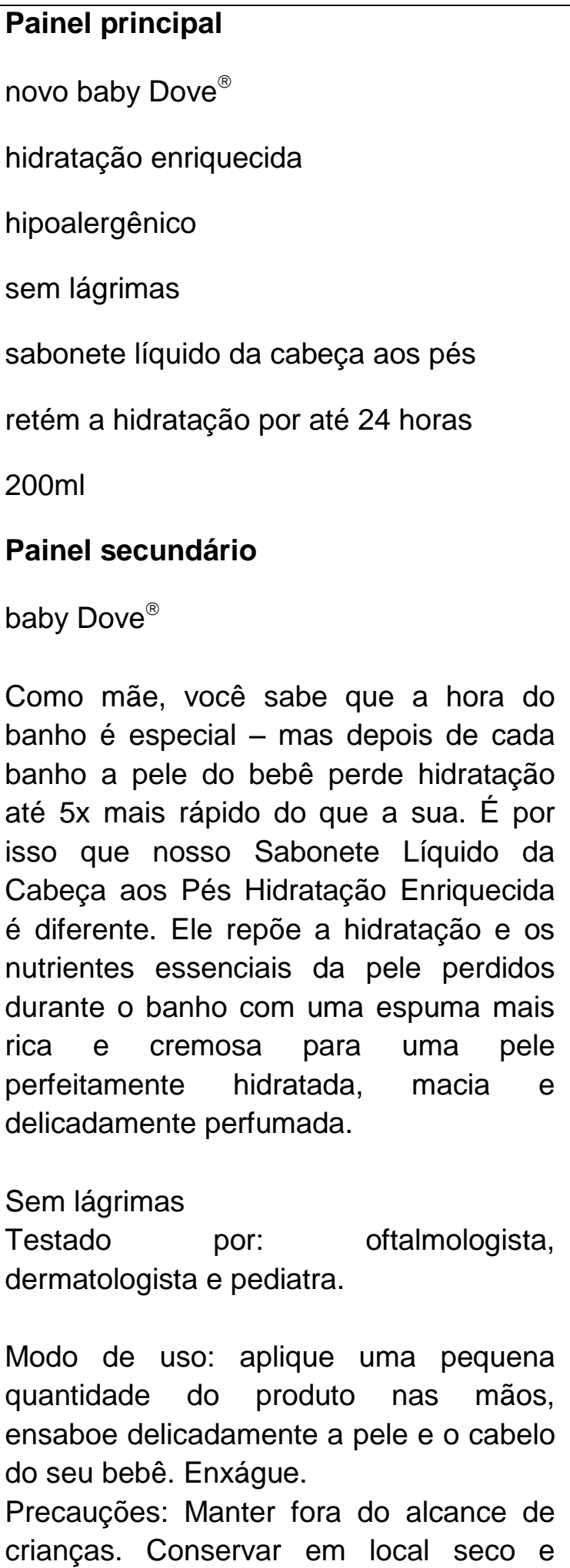 & $\begin{array}{l}\text { Você sabia que a pele do seu bebê perde a } \\
\text { hidratação até cinco vezes mais rápido do que } \\
\text { a sua depois de cada banho? É por isso que o } \\
\text { nosso sabonete líquido hidratação enriquecida } \\
\text { da cabeça aos pés é diferente. Além de } \\
\text { hidratar, ele repõe os nutrientes essenciais da } \\
\text { pele perdidos durante o banho com uma } \\
\text { espuma mais cremosa, deixando a pele do seu } \\
\text { bebê perfeitamente macia, hidratada e com um } \\
\text { cheirinho delicioso. } \\
\text { Benefícios } \\
\text { Sabonete líquido infantil hipoalergênico e com } \\
\text { pH neutro. } \\
\text { Testado por dermatologistas, pediatras e } \\
\text { oftalmologistas. } \\
\text { Espuma abundante e cremosa. } \\
\text { Deixa a pele hidratada, macia e delicadamente } \\
\text { perfumada. } \\
\text { Repõe a hidratação e os nutrientes essenciais } \\
\text { da pele perdidos durante o banho. } \\
\text { Embalagem reutilizável. Também disponível no } \\
\text { formato refil. } \\
\text { Ingredientes } \\
\text { Aqua, Glycerin, Cocamidopropyl Betaine, } \\
\text { Sodium Cocoyl Glycinate, Polyacrylate-33, } \\
\text { Parfum, Phenoxyethanol, Stearic Acid, Sodium } \\
\text { Lauroyl Isethionate, Caprylyl Glycol, Lauric } \\
\text { Acid, Styrene/Acrylates Copolymer, Sodium } \\
\text { Hydroxide, Sodium Tallowate, Tetrasodium } \\
\text { Edta, Sodium Isethionate, Sodium Stearate, } \\
\text { Etidronic Acid, Sodium Cocoate, Sodium Palm } \\
\text { Kernelate. }\end{array}$ \\
\hline
\end{tabular}


fresco. Não ingerir. Deve ser aplicado por adulto ou sob sua supervisão. Não usar na pele irritada ou lesionada. Em caso de irritação, suspender o uso e procurar um médico. Uso externo. Lote e validade: ver impressão na embalagem. Ingredientes: Aqua, Glycerin, Cocamidopropyl Betaine, Sodium Cocoyl Glycinate, Polyacrylate33, Parfum, Phenoxyethanol, Stearic Acid, Sodium Lauroyl Isethionate, Caprylyl Glycol, Lauric Acid, Styrene/Acrylates Copolymer, Sodium Hydroxide, Sodium Tallowate, Tetrasodium Edta, Sodium Isethionate, Sodium Stearate, Etidronic Acid, Sodium Cocoate, Sodium Palm Kernelate.

Esse produto foi formulado de maneira a minimizar o possível surgimento de alergias. Produzido por: Provider Indústria e Comércio S.A. Av. Alexandre Biazi, 645, Bairro Estiva - Louveira/SP CNPJ: 02.138.483/0001-10 - Sob encomenda de: Unilever Brasil Industrial LTDA. Av. das Indústrias, 315 - Vinhedo-SP - Brasil - CNPJ: 01.615.814/0064-87. Processo n. ${ }^{-}$25351.692500/2012-91 - Aut. Func.: 2.05610-6 Indústria Brasileira. SAC: 0800 727 4134. Caixa Postal 60641 - CEP 05804-970 - São Paulo - SP. babydove@atendimentounilever.com.br 


\begin{tabular}{|c|c|}
\hline \multicolumn{2}{|c|}{ Sabonete Líquido Neutro Cabeça aos Pés Lillo Baby } \\
\hline Rótulo físico & Rótulo virtual \\
\hline $\begin{array}{l}\text { Há mais de } 40 \text { anos, a Lillo cuida dos } \\
\text { nossos bebês. Entendemos o quanto a } \\
\text { pele dos bebês é delicada e merece um } \\
\text { carinho especial. Pensando nisso, criamos } \\
\text { o Sabonete Líquido Neutro Cabeça aos } \\
\text { Pés Lillo Baby. Com fórmula suave e } \\
\text { glicerinada, hipoalergênica que não irrita } \\
\text { os olhinhos, sem álcool etílico e com pH } \\
\text { neutro. Feito com muito carinho e cuidado } \\
\text { para quem você mais ama, seu bebê. Este } \\
\text { produto foi formulado de maneira a } \\
\text { minimizar possível surgimento de alergia. } \\
\text { Modo de uso: aplique diretamente sobre o } \\
\text { corpo e o cabelo do bebê. Enxágue em } \\
\text { seguida. Precauções: Uso externo. } \\
\text { Mantenha fora do alcance das crianças. } \\
\text { Suspenda o uso se observada qualquer } \\
\text { reação adversa e procure orientação } \\
\text { médica. Este produto deverá ser aplicado } \\
\text { exclusivamente por um adulto. Evite } \\
\text { contato com os olhos. Não ingerir. } \\
\text { Atenção: conservar em local seco e ao } \\
\text { abrigo da luz solar. }\end{array}$ & $\begin{array}{l}\text { O Sabonete Líquido Neutro Lillo Baby } \\
\text { limpa com suavidade os cabelos do bebê e } \\
\text { mantém a proteção natural da pele. Sua } \\
\text { fórmula suave é ideal para recém- } \\
\text { nascidos. } \\
\text { - Glicerinado } \\
\text { - Camomila } \\
\text { - Perfume Suave } \\
\text { - } 200 \text { ml } \\
\text { Conheça melhor os ativos: } \\
\text { Glicerina - Hidrata a pele do bebê } \\
\text { Colabora com a absorção da água e } \\
\text { possui ação hidratante. } \\
\text { Camomila - Maciez e Brilho } \\
\text { Promove maciez, brilho, nutrição e auxilia } \\
\text { na regeneração dos fios de cabelos. }\end{array}$ \\
\hline
\end{tabular}

